\title{
Carbon felt based-electrodes for energy and environmental applications:
}

\section{a review}

\author{
Thi Xuan Huong Le ${ }^{\mathrm{a}, \mathrm{b}}$, Mikhael Bechelany $\mathrm{a}^{\mathrm{a}^{*}}$, Marc Cretin ${ }^{\mathrm{a}^{*}}$ \\ anstitut Européen des membranes, IEM UMR-5635, Université de Montpellier, ENSCM, CNRS, \\ Place Eugène Bataillon, 34095 Montpellier cedex 5, France. \\ ${ }^{\text {b} V a n ~ L a n g ~ U n i v e r s i t y, ~} 45$ Nguyen Khac Nhu, District 1, Ho Chi Minh City, Viet Nam.
}

*Corresponding authors: mikhael.bechelany@umontpellier.fr and Marc.Cretin@umontpellier.fr

\begin{abstract}
Carbonaceous materials are abundantly used for electrochemical applications and especially for energy and environmental purposes. In this review, the carbon felt (CF) basedelectrodes are discussed in a holistic manner. First of all, the study centers on the issues relevant to pristine $\mathrm{CF}$ materials such as manufacturing method and specific properties. The various methods and equations used to identify physical values of CF material are supplied. As main part of the review, the different modification methods for $\mathrm{CF}$ electrodes are described. The novel properties of fabricated materials are characterized by physical as well as electrochemical techniques. The strengths of each method are presented in the comparison with raw $\mathrm{CF}$ electrodes. The energy applications of CF based-electrodes are figured out in various fields such as vanadium redox flow batteries (VRFB), microbial fuel cells (MFCs), biofuel cells (BFCs), capacitors, solar cells and lithium ion batteries. For environmental applications, we focus our study on the wastewater treatment containing biorefractory pollutants by electro-Fenton (EF) process. The degradation result by EF technology using CF materials is impressive when most of toxic contaminants are mineralized to non-toxic compounds at the end of the electrolysis. To decrease the cost treatment and upgrade the treatment efficiency, the EF system has been improved by using modified electrodes or new catalyst sources. The CF materials are also investigated to apply in bio-fuel cell-Fenton in which electrons were produced from fuel cell (FC) towards zero-energy depollution. Finally, the sketches about EF pilot open new gates for application of CF materials in industrial areas.
\end{abstract}


KEYWORDS: Carbon felt, modification, energy application, electro-Fenton process, hydrophilicity, conductivity, electroactive surface are, zero energy depollution.

\section{GRAPHICAL ABSTRACT}

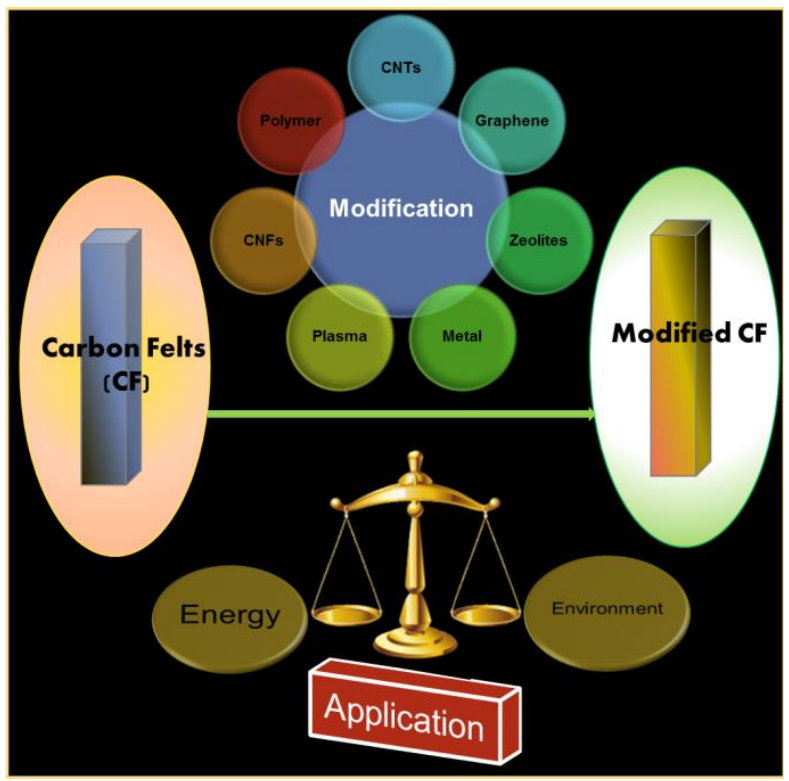




\section{TABLE OF CONTENT}

ABSTRACT

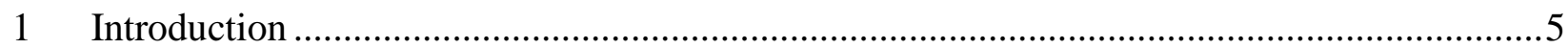

2 Manufacturing method and characterization of CF material ................................................6

2.1 Manufacturing method of CF material ..........................................................................

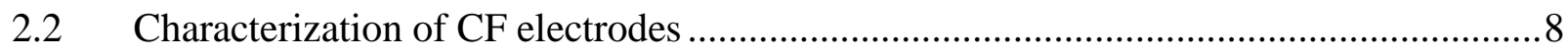

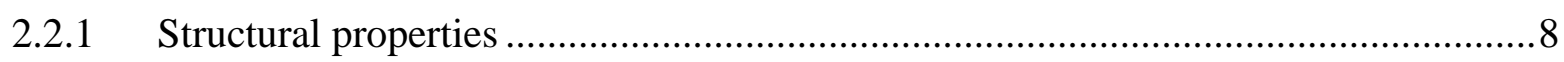

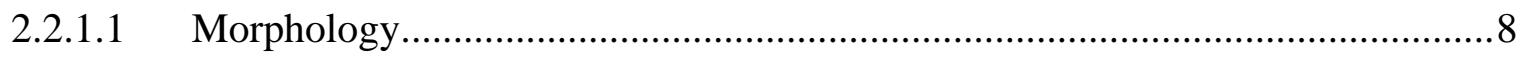

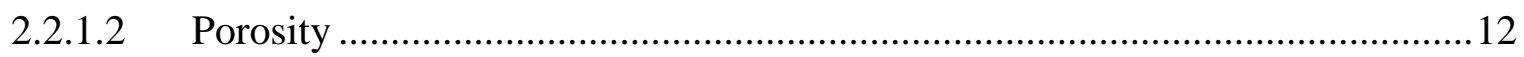

2.2.1.3 Specific surface area ……………………..............................................12

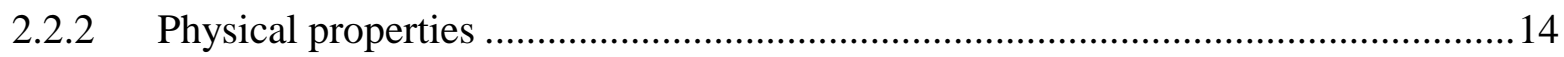

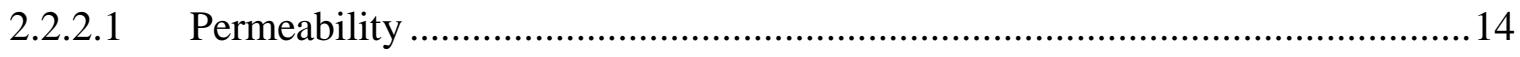

2.2.2.2 Mass transfer ...........................................................................................15

2.2.2.3 Electrical resistivity ................................................................................16

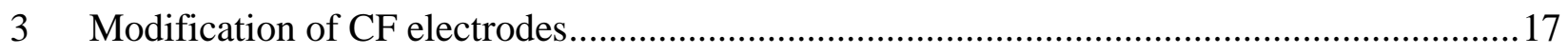

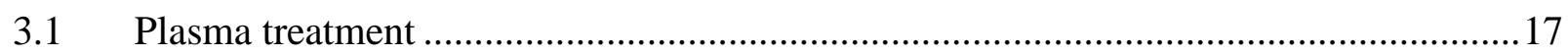

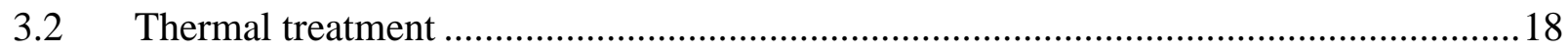

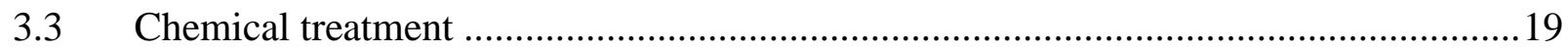

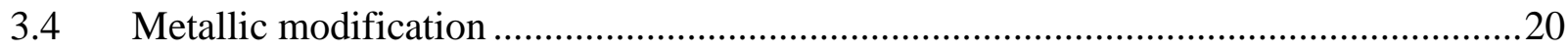

3.5 Graphene based modification .................................................................................2

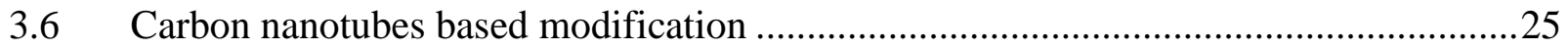

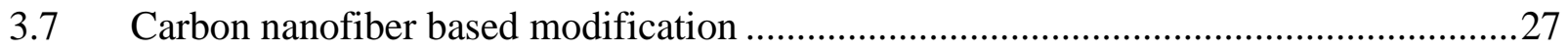

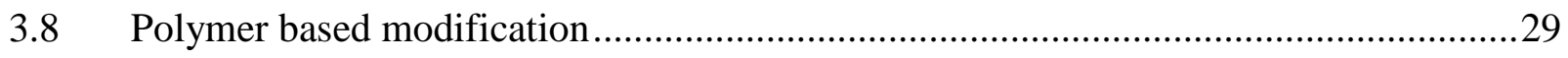

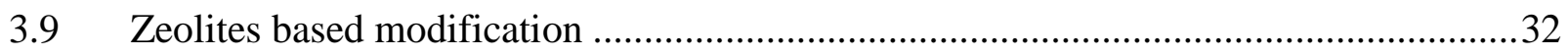

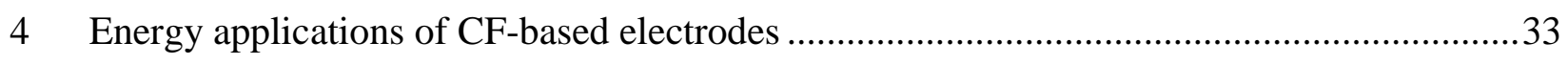

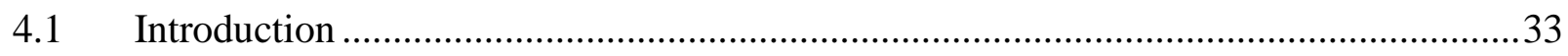

4.2 Vanadium redox flow batteries .................................................................................. 


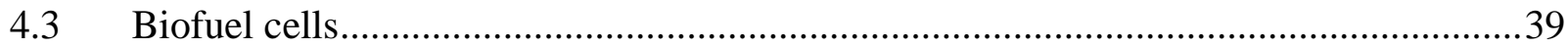

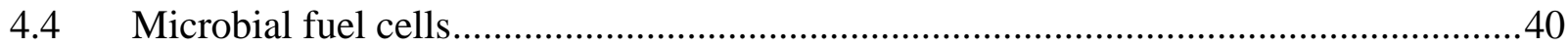

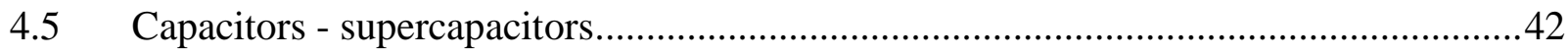

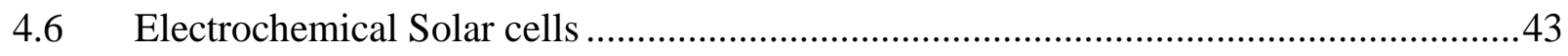

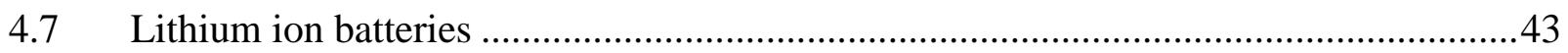

5 Application of CF-based electrodes for wastewater treatment by electro-Fenton process ....44

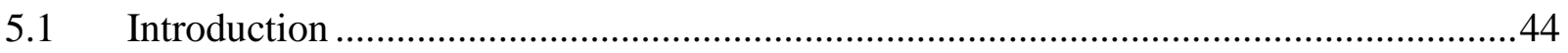

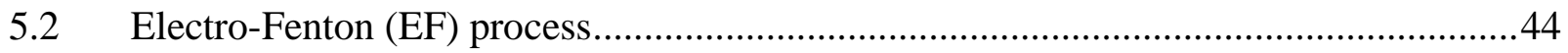

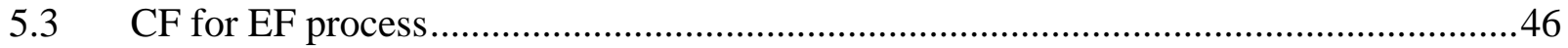

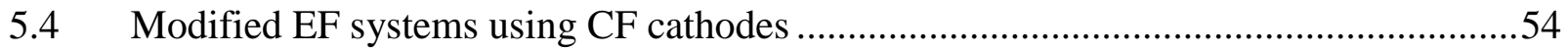

5.4.1 Modified felts cathodes for homogeneous EF..............................................54

5.4.2 Modified felts cathodes for heterogeneous EF............................................55

5.4.3 Hybrid EF system using CF cathodes ...........................................................56

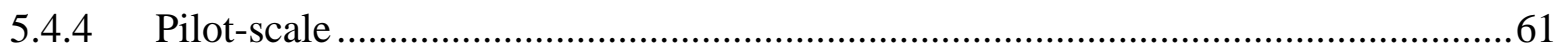

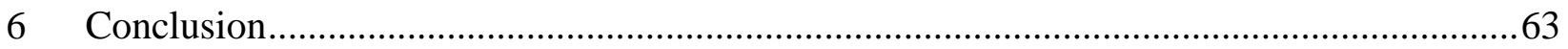

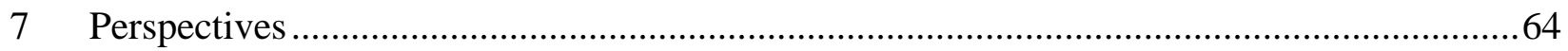

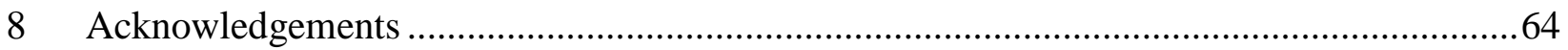

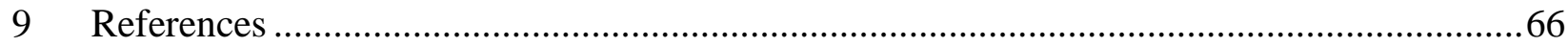




\section{Introduction}

Carbon Felt (CF) is commonly used as electrodes due to their good electronic conduction. They have high surface area and porosity able to provide abundant redox reaction sites, excellent electrolytic efficiency and mechanical stability at relatively low cost [1-4]. Other carbon-based materials like vitreous carbon, carbon sponge, carbon fiber or carbon paper have been also applied widely for electrode application. However, these materials show some limitations in comparison with CF. For example, it is impossible to manufacture a cheap electrode with vitreous carbon due to its expensive price. Carbon paper would not be a perfect choice for tubular electrode because of its rigid properties. Toward an electrode commercially available with a low price and present tenacious and stable properties, CF has been chosen as the best candidate in this review. They simultaneously have, however, some disadvantages relevant to their inadequate wettability and electrochemical activity in aqueous solutions because of their hydrophobic surface nature and poor kinetics for reduction and oxidation reactions. This partly declines the performance of pristine $\mathrm{CF}$ when it is applied at electrodes $[5,6]$. In the effort to make the CF electrodes more active, several modification methods have been adopted at various conditions. After modification process, the electrochemical activity of CF could be remarkably enhanced [6, 7].

CF based-electrodes have been the subject of few reviews relevant to energy and environmental topics. Most reviews focus on redox flow batteries (RFBs) and wastewater treatment by electrochemical advanced oxidation processes (EAOPs). Chakrabarti et al. reported some modification methods to improve the catalytic properties and the conductivity of $\mathrm{CF}$ electrodes for RFBs such as deposition of metals, addition of functional groups by chemical and thermal treatments on the electrode surface. Several methods to produce vapour grown carbon fibers, carbon nanotubes (CNTs), or nitrogenous groups on the carbon fiber surface of graphite felt (GF) electrodes were discussed [8]. The progress on felt electrodes in RFBs was still a fascinating topic in some recent reviews $[9,10]$. Beside that, $\mathrm{CF}$ was used widely as cathode materials for removal of persistent organic pollutants (POPs) in aqueous medium by EF process. According to the review of Brillas et al., carbon electrodes present many advantages like nontoxicity, good stability, conductivity, and chemical resistance [11]. The efficiency of EF system using CF cathodes was summarized in the comparison with other materials like activated carbon fiber, reticulated vitreous carbon, carbon sponge, etc. [12-14]. Obviously, reviews dedicated to CF based-electrodes have concentrated only a few of their characteristic features or 
modification methods towards individual applications. From these reviews, it is actually difficult to understand this material in detail or to choose suitable methods of modification for various demands. The surmount of this difficulty requires deeper reviews focusing on the different aspects of CF materials, which were investigated according to the following scheme:

- First, we discuss the commercial method of producing CF materials and supply the specific properties combining with methods and equations to identify physical values of CF materials.

- The most important part is the modification methods used to improve the properties of CF electrodes relating mainly to hydrophilicity, conductivity, and electroactive activity. Interestingly, the different modification methods induce different performance.

- Both pristine and CF electrodes are applied in energy field of VRFB, MFCs, BFCs, capacitors, electrochemical solar cells and lithium ion batteries. From there, we compare and discuss the upgraded efficiency of modified electrodes.

- Afterwards, we concentrated on using CF cathodes for wastewater treatment by EF technology. Unlike the previous reviews about removal POPs by EF technology, this study presented a new approach with following structure: First, we present the definition about EF process and the studies using non-modified CF cathode. In the next step, we investigated the modified EF systems on the basis of various aspects: configuration, cathode material, and catalyst. Beside that, we looked at bio-Fenton systems without input power in which clean and green energy from FC is used for EF process. Finally, with an eye towards industrial applications, some EF pilot scales were investigated for the treatment of a large volume of pollutants solution. Using solar radiation as available power for EF pre-pilot plants is also an interesting idea to grow the future research for CF-based electrodes.

- In the last part, some important conclusions and perspectives in this field were presented to open new trends for CF-based electrodes.

\section{Manufacturing method and characterization of CF material}

\subsection{Manufacturing method of CF material}

Generally, there are two types of precursors which are most commonly used for graphite/carbon felts manufacture, including polyacrylonitrile (PAN) and rayon which is a regenerated cellulose [15]. The manufacturing process for felts material is usually done via needle-punching processing and subsequently graphitization [16]. The needle punching is an 
important step which decides the internal structure, textile structures or thickness homogeneity of produced felts. Figure 2-1 describes a needle punching process where the barbs on the needles hook the fibers and insert them vertically. The layers are reinforced via rearranged fibers and the layers will be compacted and integrated with each other [17, 18]. After needle punching process, felts materials are prepared via thermal treatment. Graphite felt (GF) is manufactured by graphitization of carbon felt (CF). The processing temperature is around $1200-1600^{\circ} \mathrm{C}$ for carbon felts and $2000-2600^{\circ} \mathrm{C}$ for graphite felts. Their outward appearances are almost exactly alike Figure 2-2.

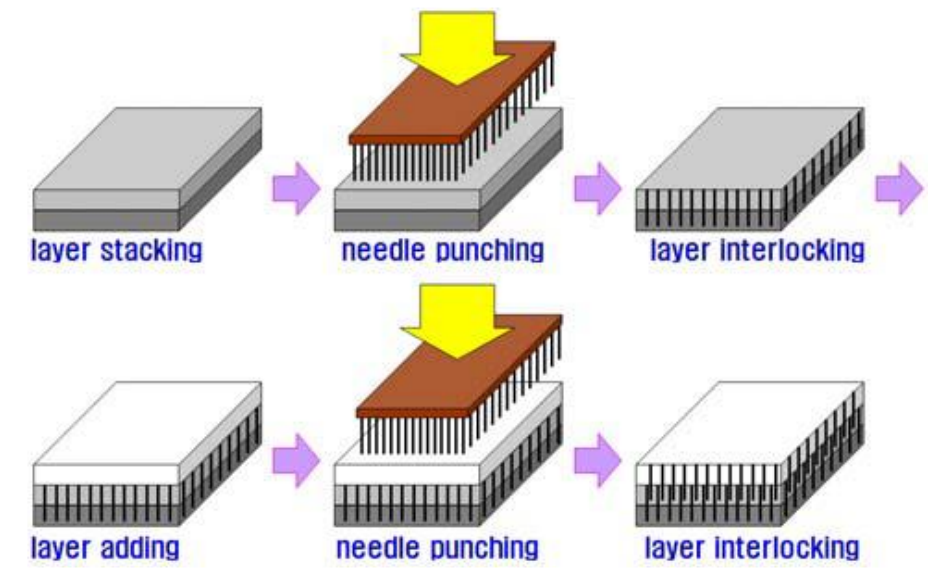

Figure 2-1. Needle punching process [17].

However, the various precursors and processing parameters used in their manufacture can impact on the graphitization stage of the felt materials, and that can lead to the differences between carbon and graphite felts (Table 2-1). Indeed, there are several hundred grades of carbon/graphite felts available from different sources, and the variation from felt to felt is considerable. Particularly, a study by Zhong et al., found the resistivity of GF based on rayon, $0.023 \Omega \mathrm{cm}$, to be much higher than that of the PAN variety, $0.0038 \Omega \mathrm{cm}$. The specific surface area of this PAN based felt, $266.86 \mathrm{~m}^{2} \mathrm{~g}^{-1}$, is slightly greater than that of the rayon based felt, $238.27 \mathrm{~m}^{2} \mathrm{~g}^{-1}$, and this may partly account for the lower electrical resistivity [19]. A study of Liu et al. showed that CF (Shanghai Q-Carbon Material Co., Ltd., China) exhibited a much higher electrocatalytic activity than GF (GFD4.6, SGL Group, Germany), due to its higher amount of C$\mathrm{OH}$ and quaternary nitrogen groups and the presence of higher amounts of defect sites [20]. 


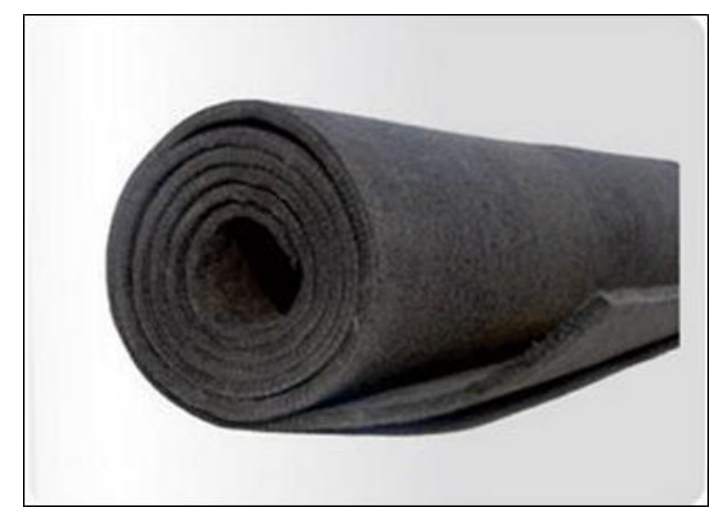

Figure 2-2. Typical shape of commercial (a)

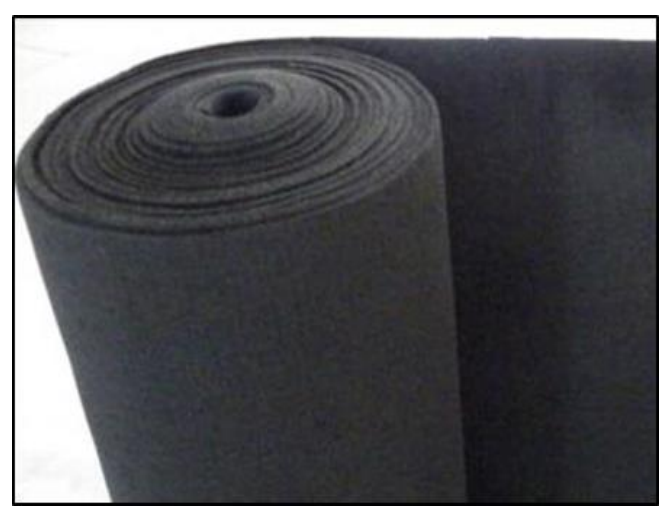
(b) GF. (Product information from CeraMaterials (http://www.ceramaterials.com/graphitecarbonfelt.html. Updated 04/2017)).

Table 2-1. Main physical and manufacturing properties of carbon and graphite felts based on rayon or PAN precursor [21].

\begin{tabular}{ccccc}
\hline \multirow{2}{*}{ Properties } & \multicolumn{2}{c}{ Carbon Felt } & \multicolumn{2}{c}{ Graphite Felt } \\
& PAN & Rayon & PAN & Rayon \\
\hline Bulk density $\left(\mathbf{g ~ c m}^{-3}\right)$ & 0.14 & $0.09-0.10$ & 0.10 & 0.08 \\
Carbon content $(\boldsymbol{\%})$ & 98.5 & $\geq 99$ & $>99.5$ & $\geq 99.9$ \\
Tensile strength $(\mathbf{M P a})$ & 0.18 & 0.13 & 0.12 & 0.10 \\
Process Temperature $\left({ }^{\circ} \mathbf{C}\right)$ & 1500 & 1400 & 2400 & $2200-2500$ \\
\hline
\end{tabular}

In brief, the differences in the precursors and manufacturing factors as well as the processing procedure employed would affect significantly the properties of the produced felts materials.

\subsection{Characterization of $\mathrm{CF}$ electrodes}

\subsubsection{Structural properties}

\subsubsection{Morphology}

From Scanning Electron Microscopy (SEM) images, carbon and graphite felts are often observed under long smooth fibres dispersed randomly with homogeneous large void spaces between them (Figure 2-3). Each fibre has cylinder-like shape with shallow grooves along the long axis which was formed by combination of thinner fibres, melted together lengthways as reported by González-García et al. [22]. The addition or cutting of thinner sheets from the original can change the thickness of the three-dimensional felts electrode. The geometrical shape 
of fibers is quite different from other materials, partly leading to various values for structural as well as physical parameters as shown in Table 2-2.
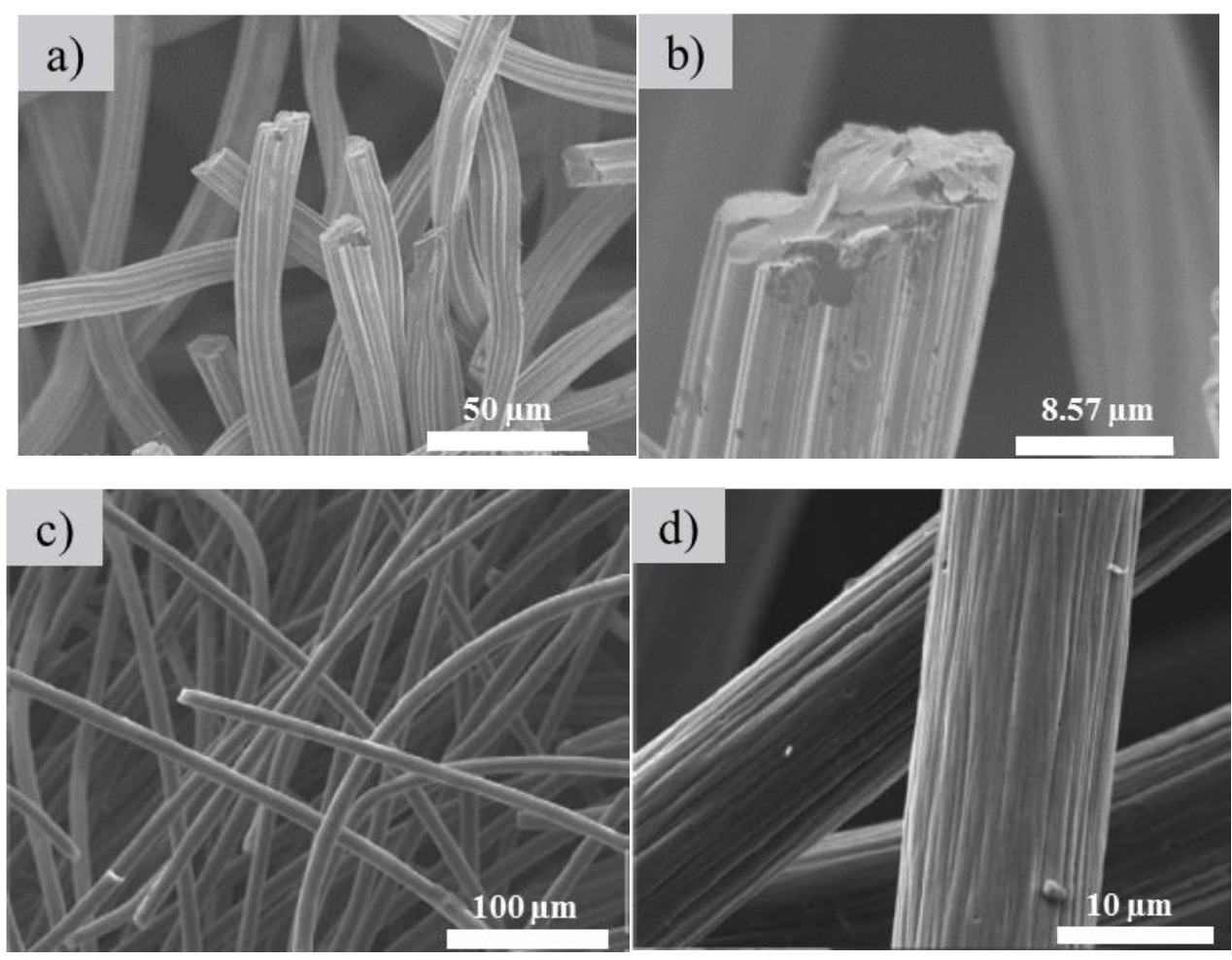

Figure 2-3. SEM images of (a, b) CF (Johnson Matthey Co., Germany, thickness $1.27 \mathrm{~cm}$ ) [23] and (c, d) GF (GFD 2.5, SGL Group, thickness $2.8 \mathrm{~mm}$ ) at various magnifications. Reprinted from Ref. [1]. Copyright (2015), with permission from Elsevier. 
Table 2-2. Textural and electrical properties of carbon and graphite felts materials.

\begin{tabular}{|c|c|c|c|c|c|c|c|c|c|c|}
\hline \multirow[b]{2}{*}{ Material } & \multirow[b]{2}{*}{ Company } & \multirow[b]{2}{*}{ Type } & \multicolumn{2}{|c|}{ Porosity } & \multicolumn{2}{|c|}{ Mean pore diameter } & \multicolumn{2}{|c|}{ Specific surface area } & \multirow{2}{*}{ 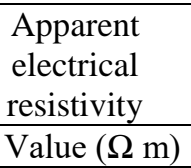 } & \multirow[t]{2}{*}{ Ref } \\
\hline & & & Value & Method & Value/m & Method & Value & Method & & \\
\hline GF & SGL & $\begin{array}{l}\text { Rayon (3 } \\
\text { mm) }\end{array}$ & & & & & $<2\left(\mathrm{~m}^{2} \mathrm{~g}^{-1}\right)$ & $\mathrm{BET}^{\mathrm{e}}$ & & [24] \\
\hline $\mathrm{CF}$ & $\begin{array}{l}\text { Johnson } \\
\text { Matthey, } \\
\text { Germany }\end{array}$ & & & & & & $0.09\left(\mathrm{~m}^{2} \mathrm{~g}^{-1}\right)$ & BET & & [25] \\
\hline $\mathrm{CF}$ & $\begin{array}{c}\text { Nippon Chem. } \\
\text { GF-3F } \\
\text { Shanghai }\end{array}$ & $\begin{array}{l}\text { PAN (3 } \\
\text { mm) }\end{array}$ & & & & & $\begin{array}{l}0.0583 \\
\left(\mathrm{~m}^{2} \mathrm{~g}^{-1}\right)\end{array}$ & BET & & {$[5]$} \\
\hline GF & $\begin{array}{c}\text { Energy Carbon } \\
\text { Limited Co., } \\
\text { China }\end{array}$ & & & & & & $0.33 \mathrm{~m}^{2} \mathrm{~g}^{-1}$ & BET & & [26] \\
\hline \multirow[t]{8}{*}{ GF } & $\begin{array}{l}\text { Carbone- } \\
\text { Lorraine }\end{array}$ & RVG 2000 & 0.95 & Unknown & & & & & $3.5 \times 10^{-3}$ & [22] \\
\hline & & RVC 1000 & & & $1.19 \times 10^{-4}$ & & $31000\left(\mathrm{~m}^{-1}\right)$ & $\begin{array}{c}\text { Filamentary } \\
\text { analogy }\end{array}$ & & \\
\hline & & RVC 2000 & & & $2.57 \times 10^{-4}$ & & $15000\left(\mathrm{~m}^{-1}\right)$ & $\begin{array}{c}\text { Filamentary } \\
\text { analogy }\end{array}$ & & \\
\hline & & RVC 4000 & & & $1.60 \times 10^{-4}$ & & $23500\left(\mathrm{~m}^{-1}\right)$ & $\begin{array}{c}\text { Filamentary } \\
\text { analogy }\end{array}$ & & \\
\hline & & RVC 4002 & 0.84 & $\begin{array}{l}\text { Apparent } \\
\text { and true } \\
\text { density }\end{array}$ & $2.94 \times 10^{-4}$ & Ergun & $\begin{array}{c}33684\left(\mathrm{~m}^{-1}\right)^{\mathrm{a}} \\
3369\left(\mathrm{~m}^{-1}\right)^{\mathrm{b}}\end{array}$ & $\begin{array}{c}\text { Filamentary } \\
\text { analogy }\end{array}$ & $2.4 \times 10^{-1} \mathrm{c}$ & \\
\hline & & & 0.984 & Simulation & $0.12 \times 10^{-4}$ & $\begin{array}{c}\text { Filamentary } \\
\text { analogy }\end{array}$ & $\begin{array}{c}22100-22700 \\
\left(\mathrm{~m}^{-1}\right)\end{array}$ & Ergun & $2.7 \times 10^{-3 \mathrm{~d}}$ & \\
\hline & & & & & & & $\begin{array}{c}(0.067-6) \times \\
10^{7}\left(\mathrm{~m}^{-1}\right)\end{array}$ & Porosimetry & & \\
\hline & & & & & & & $\begin{array}{c}(0.8-2.8) \times \\
10^{6}\left(\mathrm{~m}^{-1}\right)\end{array}$ & BET & & \\
\hline $\mathrm{CF}$ & SiGRI & $\begin{array}{l}\text { Sigratherm } \\
\text { GFD } 5\end{array}$ & 0.95 & Unknown & $1.52 \times 10^{-4}$ & & $\begin{array}{c}24000-60000 \\
\left(\mathrm{~m}^{-1}\right)\end{array}$ & $\begin{array}{l}\text { Filamentary } \\
\text { analogy-BET }\end{array}$ & & [22] \\
\hline \multirow[t]{2}{*}{$\mathrm{CF}$} & Fiber Materials & $\mathrm{CH}(0.175)$ & 0.86 & C density & $1.56 \times 10^{-4}$ & & $11000\left(\mathrm{~m}^{-1}\right)$ & $\begin{array}{c}\text { Filamentary } \\
\text { analogy }\end{array}$ & & [22] \\
\hline & & $\mathrm{CH}(0.25)$ & 0.90 & & $2.04 \times 10^{-4}$ & & $8800\left(\mathrm{~m}^{-1}\right)$ & $\begin{array}{c}\text { Filamentary } \\
\text { analogy }\end{array}$ & & \\
\hline
\end{tabular}




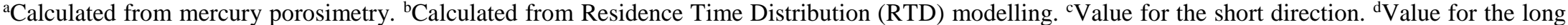
direction. ${ }^{\mathrm{e} B r u n a u e r-E m m e t t-T e l l e r}$ 


\subsubsection{Porosity}

The Table 2-2 reveals that the porosity of CF usually oscillates in a range of $0.8 \div 1$. To calculate this value, the helium density and mercury porosimetry (density methods) are usually applied because these methods seem suitable for compressible materials such as CF. Porosity, $\varepsilon$, can be calculated from the values of apparent and true densities, according to Eq. (2-1):

$\varepsilon=\frac{\left(\rho_{R}-\rho_{A}\right)}{\rho_{R}}$

where the apparent density of the CFs $\left(\rho_{A}\right)$, and the true density of the sample $\left(\rho_{R}\right)$ are determined by using a dilatometer prepared for mercury porosimetry and helium, respectively.

\subsubsection{Specific surface area}

Different methods for identifying the specific surface area can give out different values, so comparison of this parameter between several studies is difficult. Three main methods for identification of specific surface areas of felts, including: physical methods (the permeametry mercury porosimetry [27], physical adsorption of gases [28]); structural methods (the filamentary analog procedure [29]); and electrochemical methods [30]. For example, in filamentary analog method, the specific surface area is calculated by Eq. (2-2) where all fibers of the CFs are considered fibers as smooth, long, and perfect non-porous cylinders.

$A_{e}=\frac{4}{d_{f}}(1-\varepsilon)$

Where $\varepsilon$ is the porosity of the CFs, $A_{\mathrm{e}}\left(\mathrm{m}^{2} \mathrm{~m}^{-3}\right)$ is the specific surface area, and $d_{\mathrm{f}}$ is the diameter of the fiber.

In the permeametry method performed, $A_{e}$ is calculated by using the Ergun equation:

$A_{e}=A_{s}(1-\varepsilon)$

$A_{S}^{4}=\frac{N^{3}(0.096 L \rho)^{2}}{M^{2}(5 \gamma \mu L)^{3}} \frac{\varepsilon^{3}}{(1-\varepsilon)^{4}}$

where $\rho$ is the fluid density, $\mu$ is the dynamic viscosity of the fluid, $\gamma$ is the circularity factor of the pores, $\mathrm{N}$ and $\mathrm{M}$ are the empirical constants which depend on physical and geometrical parameters of the measuring system.

The adsorption isotherms and mercury porosimetry methods are also utilized. For example, by dynamic BET method using the Quantadsorb Model QS-16 (Quantachrome Corp., $\mathrm{NY}$ ), the specific surface of CF (SIGRI GmbH, Meitigen, $5.0 \mathrm{~mm}$ thickness) was obtained at 6.0 $\mathrm{x} 10^{4} \mathrm{~m}^{-1}$ [31]. The specific surface area of PAN-based CF was identified at $1.0 \mathrm{~m}^{2} \mathrm{~g}^{-1} \mathrm{using}$ the 
BET method [32]. Meanwhile, using the mercury-intrusion method (the results were analyzed by a computer system (Malvem Instruments, UK)), the values of two kinds of GF from rayon and PAN precursors were found as 238.27 and $266.86 \mathrm{~m}^{2} \mathrm{~g}^{-1}$, respectively (Table 2-3). Obviously, there was a significant difference in specific surface area between main pores and total measured pores for each felt sample. This illustrated the unique structural characteristics of the GF with the coexistence of macropores (space between fibres of the felt as observed on SEM in part 2.2.1.1) and micropores [19].

Table 2-3. Textural characteristics of rayon and PAN based GF [19].

\begin{tabular}{cccccc}
\hline Felt & Company & $\begin{array}{c}\text { Main pore } \\
\text { diameter } \\
(\boldsymbol{\mu m})\end{array}$ & $\begin{array}{c}\text { Main pore } \\
\text { volume/total } \\
\text { measured pore } \\
\text { volume }(\%)\end{array}$ & $\begin{array}{c}\text { Specific surface } \\
\text { area for main } \\
\text { pores }\left(\mathbf{m}^{\mathbf{2}} \mathbf{g}^{-\mathbf{1}}\right)\end{array}$ & $\begin{array}{c}\text { Specific surface } \\
\text { area for total } \\
\text { measured pores } \\
\left(\mathbf{m}^{\mathbf{2}} \mathbf{g}^{-1}\right)\end{array}$ \\
\hline $\begin{array}{c}\text { Rayon- } \\
\text { GF } \\
(3 \mathrm{~mm})\end{array}$ & $\begin{array}{c}\text { Fibre Materials, Inc., } \\
\text { Maine, USA }\end{array}$ & $188.5-36.5$ & 93.2 & 0.329 & 238.27 \\
$\begin{array}{c}\text { PAN- } \\
\text { GF }(2.5 \\
\text { mm })\end{array}$ & $\begin{array}{c}\text { Sigri Electrograpit } \\
\text { GmbH, Germany }\end{array}$ & $188.5-13.0$ & 92.8 & 0.390 & 266.86 \\
\hline
\end{tabular}

Considering electrochemical applications of felts, the electroactive surface area (Ip) of cathodes was calculated from voltamperometric measurements according to the Randles-Sevcik formula $(2-5)[33,34]$.

$I p=2.69 \times 10^{5} \times A D^{1 / 2} n^{3 / 2} \gamma^{1 / 2} C$

where $\mathrm{A}$ is the electrode area $\left(\mathrm{cm}^{2}\right), \mathrm{C}$ is the probe molecule concentration in the bulk solution $\left(\mathrm{mol} \mathrm{cm}{ }^{-3}\right), \mathrm{n}$ is the number of electrons involved in the reaction, $\gamma$ is the scan rate of the potential perturbation $\left(\mathrm{V} \mathrm{s}^{-1}\right)$ and $\mathrm{D}$ is the diffusion coefficient of the molecule $\left(\mathrm{cm}^{2} \cdot \mathrm{s}^{-1}\right)$.

For example, Robert et al. used simulations method in combination with experimental voltammograms to extract electrochemical properties of the felts electrodes [1]. This experiment was performed in a three electrodes-cell including a saturated calomel electrode (SCE, IJ Cambria Scientific Ltd) as the reference, platinum (Pt) wire mesh (Metrohm, UK) as the counter electrode, and GF (SGL GFD2.5, thickness $2.8 \mathrm{~mm}$ ) as a working electrode. By running cyclic voltammograms (CVs) at $0.05 \mathrm{~V} \mathrm{~s}^{-1}$ in an aqueous solution of $0.1 \mathrm{mM}$ ferricyanide and $0.1 \mathrm{M}$ $\mathrm{KNO}_{3}$, the electrochemical surface area of this felt was identified at $50 \mathrm{~cm}^{2}$ with geometric surface area of $10 \mathrm{~cm}^{2}$. 


\subsubsection{Physical properties}

\subsubsection{Permeability}

The permeability can be changed over a wide range among other materials relying on the hydrophobic nature of felts and their porosity. The value is defined based on the Darcy law where it is understood as the velocity of a fluid via a volume unit of a porous medium (per unit of differential pressure). The value of the permeability coefficient is often applied to identify the ease for a fluid to pass through a porous material [35]. In fact, the better the porosity of a porous material leads to the higher the permeability coefficient (PC) because the fluid flows will pass easily. The PC is calculated through Eq. (2-6) by the Ergun method:

$P C=\frac{\varepsilon^{3}}{K^{\prime \prime} A_{e}^{2}}$

where Ae is the specific surface area, $\varepsilon$ is the porosity, and $K^{\prime \prime}$ is the Kozeny constant at 32.824 for material with high porosity $(\varepsilon>0.98)$.

The high hydrophobicity of felts materials can reduce simultaneously the permeability. Most of felts are hydrophobic and difficult to wet (Figure 2-4). This phenomenon was found commonly in researches about carbon and GF [1,25]. The apparent high contact angle created a quasi-super-hydrophobic surface similar to that reported by Banks et al. for graphene foam [36].
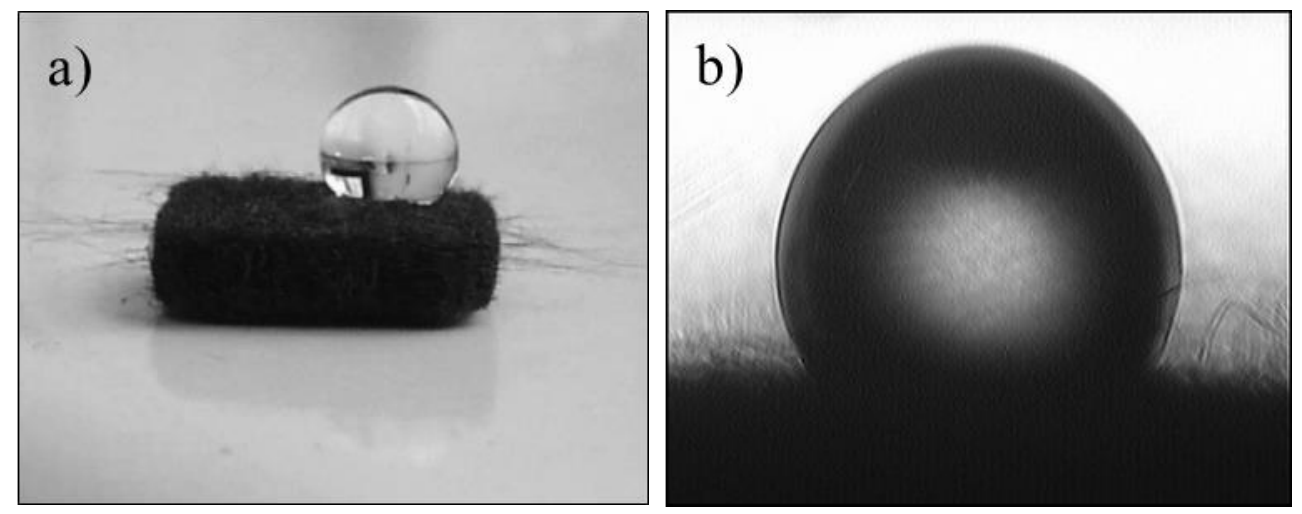

Figure 2-4. Shape of water droplet on (a) GF (SGL GFD2.5, thickness $2.8 \mathrm{~mm}$ ) and (b) CF (Johnson Matthey Co., Germany, thickness $1.27 \mathrm{~cm}$ ). Reprinted from Ref. [1] and [25]. Copyright $(2015,2016)$, with permission from Elsevier. 


\subsubsection{Mass transfer}

Study of the mass-transfer characteristics of the CF electrode is performed in an electrochemical flow cell (Figure 2-5) [31]. Mass transfer coefficients have been obtained for a flow-through felts electrode using the limiting-current technique and assuming plug-flow conditions for the range: $25<\mathrm{Pe}<1700$ ( $\mathrm{Pe}=$ Peclet number relative to felt as a porous material). This value can be calculated by Eq. (2-7):

$k=-\frac{u}{a L} \ln \left[1-\frac{I_{l}}{F S C_{0} u}\right]$

where $\mathrm{k}$ is the mass transfer coefficient, $\mathrm{L}$ is the electrode length $(\mathrm{m}), \mathrm{u}$ is the flow velocity of electrolyte $\left(\mathrm{m} \mathrm{s}^{-1}\right), \mathrm{F}$ is the Faraday constant $\left(96,486 \mathrm{C}_{\text {equivalent }}^{-1}\right), \mathrm{C}_{0}$ is the input concentration of electroactive species $\left(\mathrm{mol} \mathrm{L}{ }^{-1}\right), a$ is the specific surface area $\left(\mathrm{m}^{-1}\right), \mathrm{I}_{1}$ is the limiting current (A), and $\mathrm{S}$ is the cross-section of electrode $\left(\mathrm{m}^{2}\right)$. The mass transfer coefficients were identified for some kinds of GF as listed in Table 2-4.

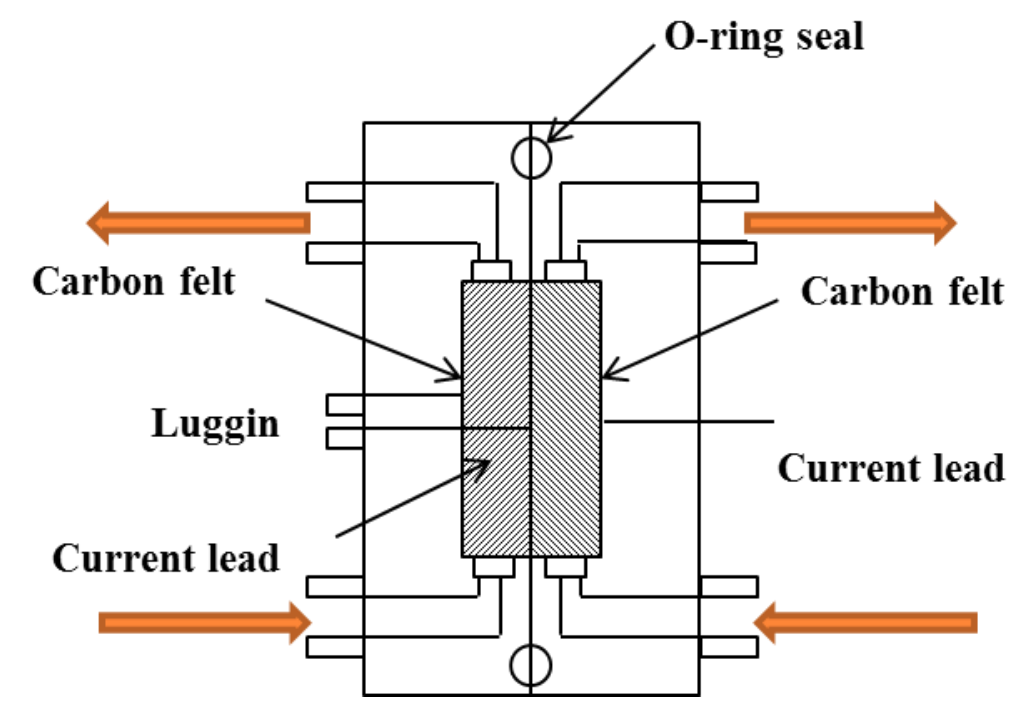

Figure 2-5: Schematic diagram of electrochemical cell for the identification of the mass transfer of CF. Reprinted from Ref. [31]. Copyright (1991), with permission from Elsevier.

Table 2-4. The mass transfer coefficient of felts material [37].

\begin{tabular}{cccccc}
\hline Reaction & $\begin{array}{c}\text { Supporting } \\
\text { electrolyte }\end{array}$ & Electrode material & $\mathbf{A}\left(\mathbf{c m}^{-1}\right)$ & $\mathbf{k}\left(\mathbf{c m ~ s}^{-\mathbf{1}}\right)$ & Ref. \\
\hline $\begin{array}{c}F e(C N)_{6}^{3-} / \\
\mathrm{KCl} \text { or KOH } 0.5\end{array}$ & $\mathrm{GF}$ (thickness $2 \mathrm{~mm})$ & 160 & $1.9 \times 10^{-2} \vartheta^{0.352}$ & {$[38]$} \\
$\left.\mathrm{Br}_{2} / \mathrm{Br}\right)_{6}^{4-}$ & $\mathrm{M}$ & $\mathrm{ZnBr}($ thickness $17.5 \mathrm{~mm})$ & 110 & $1.3 \times 10^{-3} \vartheta^{0.72}$ & {$[39]$} \\
\hline
\end{tabular}




\begin{tabular}{|c|c|c|c|c|c|}
\hline & $\begin{array}{c}\mathrm{ZnCl}_{2} 1 \mathrm{M}+ \\
\mathrm{KCl}^{3} \mathrm{M}\end{array}$ & (thickness $25 \mathrm{~mm}$ ) & 88 & $1.2 \times 10^{-3} \vartheta^{0.61}$ & \\
\hline $\begin{array}{c}F e(C N)_{6}^{3-} / \\
F e(C N)_{6}^{4-}\end{array}$ & $\mathrm{KOH} 1 \mathrm{M}$ & GF (length of $83 \mathrm{~mm}$ ) & 113 & $1.6 \times 10^{-2} \vartheta^{0.4}$ & {$[40]$} \\
\hline
\end{tabular}

\subsubsection{Electrical resistivity}

The electrical resistivity, $r_{\text {felts, }}$ of a CF material can be calculated from Eq. (2-8):

$r_{f e t}=\frac{4}{(1-\varepsilon)} r_{c}$

Where $r_{\mathrm{c}}$ is the electrical resistivity of the electrode material, and $\varepsilon$ is the porosity.

Because of the great number of different felts types and the calculation methods, a wide range of electrical resistivity values for carbon can be found in the literature. As for instance on RVC 4002 supplied by Carbone-Lorraine, this value altered at least 100 times from $2.4 \times 10^{-1} \Omega$ $\mathrm{m}$ to $2.7 \times 10^{-3} \Omega \mathrm{m}$ by using two determination methods for the porosity $(\varepsilon)$. Similarly, this value is also variable nearly 100 times between two kinds of GF RVG 2000 and RVC 4002 which are provided from the same company (Table 1).

The value of the electrical conductivity can be roughly estimated from the $I / V$ curves at $V=0 \mathrm{~V}$ by using the Eq. (2-9):

$\sigma=\frac{L}{l * e}\left(\frac{d I}{d U}\right)_{(V=0 V)}$

where $l$ is the width, e is the thickness of the CFs and $L$ is the distance between the two silver electrodes (Figure 2-6).

The value of the electrical conductivity of the CF, was found by Wang et al. to be approximately $280 \mathrm{~S} \mathrm{~m}^{-1}$ [41], which was in good agreement with the $285 \mathrm{~S} \mathrm{~m}^{-1}$ for the electrical conductivity of RVG 2000 GF [42].
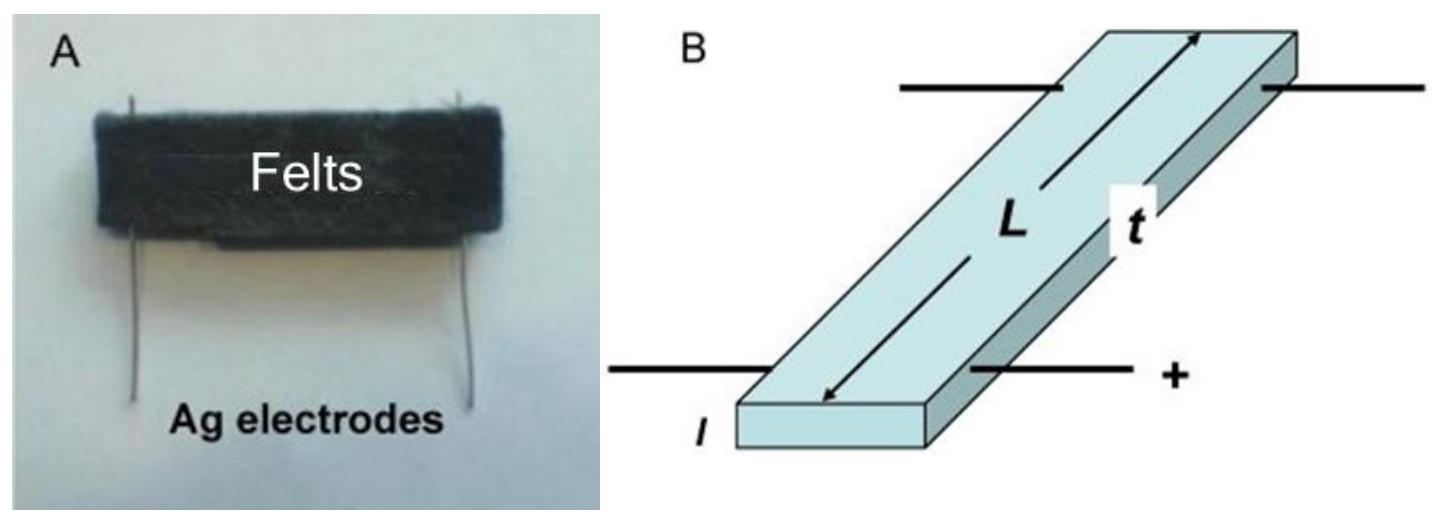
Figure 2-6. The device used to identify the electrical conductivity measurements of the felts. Reprinted from Ref. [41]. Copyright (2011), with permission from Elsevier.

\section{Modification of $\mathrm{CF}$ electrodes}

\subsection{Plasma treatment}

The purpose of plasma treatment is to improve the wettability of commercial CF due to the growth of oxygen-containing functional groups or/and nitrogen doping on the surface of fibers, and both of which enhanced the electrochemical reactivity. In particularly, oxygen plasma treatment was carried out in a radiofrequency (rf) plasma setup and felts were putted into the plasma chamber which was filled by oxygen. This process was controlled by the treatment time, the power of the rf generator and the oxygen pressure [24]. In 2015, Chen et al. reported the modification of felts (COS1011,CeTech, Taiwan, thickness $6 \mathrm{~mm}$ ) with atmospheric pressure plasma jets (APPJs) [43]. The APPJs treatment was performed on the felts under the single spot and scanning modes with the presence of $\mathrm{N}_{2}$ flow rates like in Figure 3-1. The formation of specific oxygen functional groups was observed after the plasma treatment. The X-ray photoelectron spectroscopy (XPS) measurement revealed that this method rather favored the formation of phenolic $(\mathrm{C}-\mathrm{O})$ groups than carboxyl $(\mathrm{C}=\mathrm{O})$ groups [24]. However, the plasma treatment process only often increases the amount of functional groups on felts and not remarkably the surface area. In a study of Shao et al. proved that the oxygen-containing functional groups, nitrogenous groups can also improve electrocatalytic activity of carbon electrode materials for the redox reactions. This comes from the reason that carbon atoms adjacent to nitrogen atoms having high positive charge density to counterbalance the strong electronic affinity of the nitrogen dopants. These positively charged carbon atoms can act as the active sites for the oxidation reactions, and contemporaneously the five valence electrons of nitrogen atoms create an extra-charge to the bond of graphene layers. Consequence, both the basicity of carbon and the electrical conductivity of nitrogen doped carbon will be increased [44]. Furthermore, nitrogen doping can also make CF materials more hydrophilic to increase the electrochemically active sites [16]. Briefly, the increase amount of surface-active oxygen and nitrogenous groups by plasma treatment can enhance electrochemical performance of the modified material through facilitating charge-transfer between felts electrodes and electrolytes $[24,45]$. 


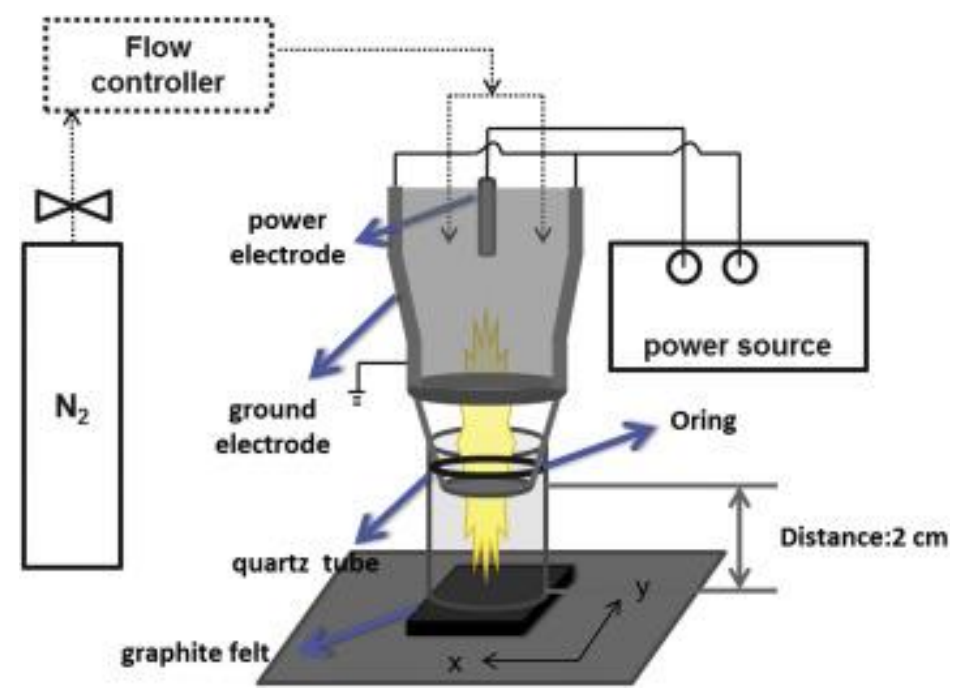

Figure 3-1: Schematic diagram of atmospheric pressure plasma jet. Reprinted from Ref. [43]. Copyright (2015), with permission from Elsevier.

\subsection{Thermal treatment}

The thermal treatment is a simple way for felts modification where samples are annealed in a furnace feeding by gas flow containing oxygen and/or nitrogen. This modification brings to benefits towards upgradation the properties of felts electrodes like plasma treatment in order to improve the electrochemical properties and the hydrophilicity [46]. A significant enhancement of the electrochemical activity was observed in the study of Zhong et al. on two kinds of GF, based on rayon or PAN precursors, after thermal treatment [19]. It was found that the electrical conductivity of the PAN based felts was higher than that of its rayon-based one. XPS analysis pointed out that the rayon based felts reacted more easily with oxygen to form C-O groups, while the PAN based felts was quite difficult for the oxidation to produce the carbon-oxygen groups. In view of the fact that the microcrystalline structure of the rayon felts made it more extensive oxygen interaction. In addition, the nitrogen-doped GF electrodes which were fabricated by heat treatment under $\mathrm{NH}_{3}$ atmosphere at $600{ }^{\circ} \mathrm{C}$ and $900{ }^{\circ} \mathrm{C}$ in a tubular furnace, showed a higher electrochemical performance. The enhanced electrochemical properties of the modified electrodes are attributed to the increased electrical conductivity, the increase of active sites amount, and the improved wettability provided by the introduction of the nitrogenous groups on the surface of GF $[16,47]$. Interestingly, the heat treatment can also improve the surface area of the pristine electrodes. After the heat treatment in air at $400{ }^{\circ} \mathrm{C}$, the surface area of the modified felts increased by more than ten times in comparison to the pristine one based on rayon ( $S G L$, thickness $3 \mathrm{~mm}$ ) [24]. This value was $1344 \%$ higher than bare PAN-CF (Nippon Chem. GF-3F, 
thickness 3mm) [5]. In the same way, thermal treatment by a mixture of $\mathrm{N}_{2} / \mathrm{O}_{2}$ with $1 \%$ of oxygen at $1000{ }^{\circ} \mathrm{C}$ for $1 \mathrm{~h}$ could also increase the $\mathrm{S}_{\mathrm{BET}}$ of commercial CF (Johnson Matthey Co., Germany, thickness $1.27 \mathrm{~cm}$ ) up to $63.88 \mathrm{~m}^{2} \mathrm{~g}^{-1}$, around 700 times higher than non-treated one. As further benefit of this method, the crystalline average size was also ameliorated due to the fact that thermal treatment will selectively etch the amorphous carbon [25].

\subsection{Chemical treatment}

Chemical treatment of CF mainly involves the use of chemicals like nitric acid and/or sulfuric acid in order to activate the surface of felt materials. The samples could be chemically treated by refluxing/boiling in sulphuric acid, nitric acid or by their mixture in order to fabricate felts with a large amount of chemisorbed oxygen on the surface [48, 49]. After treatment procedure, the felts must be washed thoroughly with distilled water and then vacuum dried before using as electrodes. The rise of acid concentration induced the increase of the electrochemical performance of modified electrode [50]. It came from the reason that the increased electrocatalytic activity of the treated GF was thus attributed to the increased concentration of $\mathrm{C}-\mathrm{O}$ and $\mathrm{C}=\mathrm{O}$ functional groups on the surface. The role of oxygen groups towards properties of felts electrodes was well discussed in section 3.1. The combination between thermal and chemical treatments sometimes is necessary to improve the electrochemical behavior of the felts [51]. Additionally, the oxygen functional groups like $\mathrm{COOH}, \mathrm{CH}=\mathrm{O}, \mathrm{OH}$, etc. and micropores could be formed on the surface of the $\mathrm{CF}$ electrodes by $\mathrm{KOH}$ activation at around $800{ }^{\circ} \mathrm{C}$. After modification, the electrochemical propertied was increased significantly in comparison with the pristine PAN-GF (Gansu Haoshi Carbon Fiber Co., Ltd.) which came from not only the oxygencontaining groups, but also a huge amount of exposed edge carbon sites [52]. The growth up of functional group on felts electrodes can be done via another method called electrochemical oxidization, which requires the application of constant current or potential in acidic solutions like $1 \mathrm{M} \mathrm{H}_{2} \mathrm{SO}_{4}$. The modification following the electrochemical oxidation way was successfully applied to improve the properties (i.e. the hydrophilicity, electrocatalytic activity) of different felts like graphite (Shanghai Energy Carbon Limited Co., China) [53] or GF (Sanye Carbon Co., Ltd.) [54]. Low-cost chemical reagents like ethanol and hydrazine hydrate were applied for chemically modified the graphite as well. Interestingly, after modification, some carbon nanoparticles (Figure 3-2 c) and oxygen/ nitrogen containing functional groups appeared simultaneously on the cathode surface, which greatly improved the surface hydrophilic property and the electrocatalytic activity. The contact angles were reduced gradually from $141^{\circ}, 123^{\circ}$ to 
$110^{\circ}$ for bare GF (Shanghai Qijie Carbon Material Co., LTD), GF-ethanol and GFethanol/hydrazine, respectively (Figure 3-2 d, e, f) [55, 56].
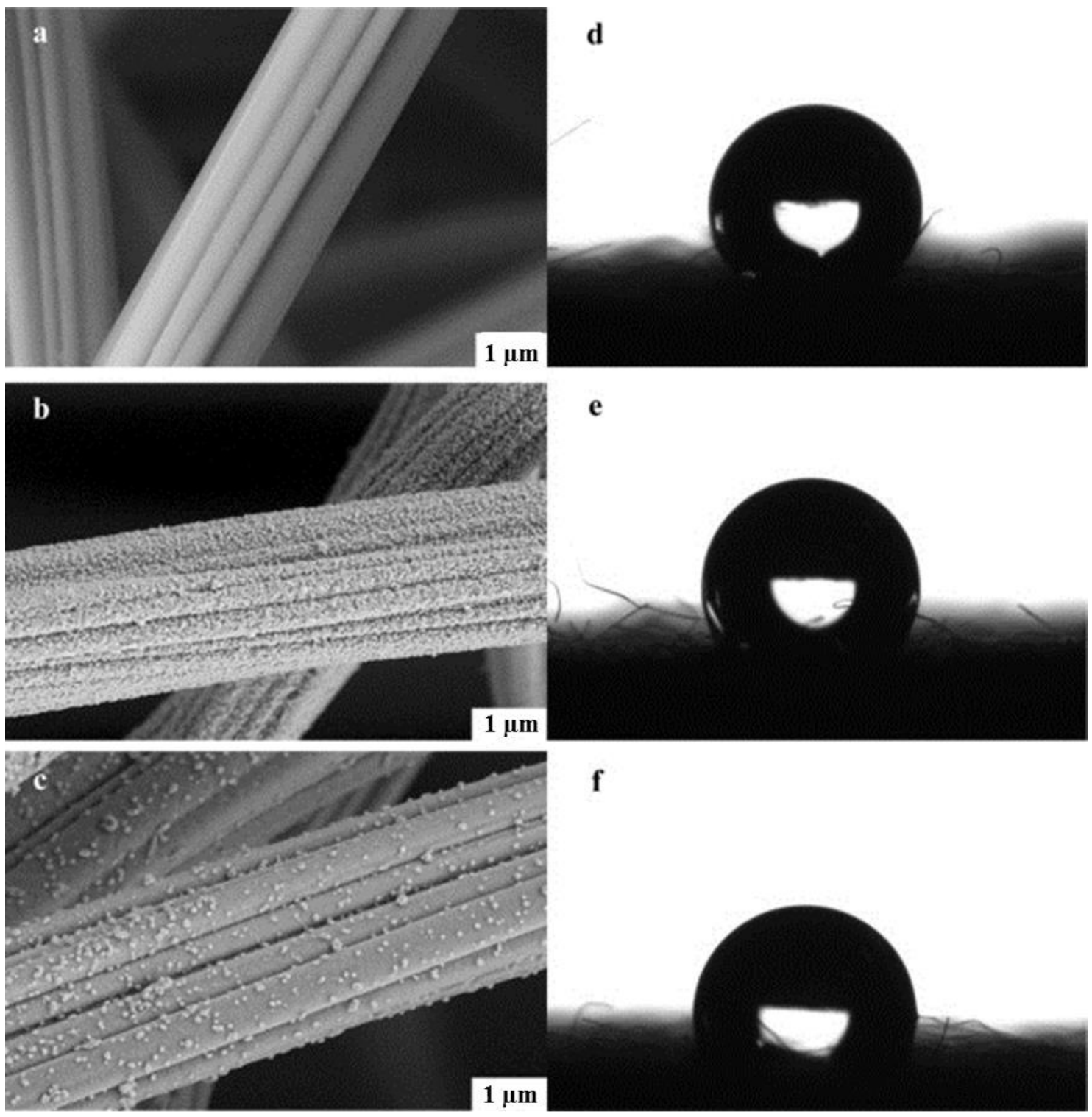

Figure 3-2. SEM images and contact angles of GF (a, d), GF-ethanol (b, e) and GFethanol/hydrazine (c, f). Reprinted from Ref. [56]. Copyright (2014), with permission from Elsevier.

\subsection{Metallic modification}

The metallic modification is towards enhancement of the electro-conductivity of felts electrode materials. Coating metal on the felts fibres can be performed through a simple way of impregnation with solutions containing metallic ions like $\mathrm{Pt}^{4+}, \mathrm{Pd}^{2+}, \mathrm{Au}^{4+}, \mathrm{Mn}^{2+}, \mathrm{Te}^{4+}, \mathrm{In}^{3+}, \mathrm{Ir}^{3+}$, etc. In few cases, the CF was thermally treated at high temperatures $[48,57]$. The amount of 
metal on the fibre surface can change depending on the used method and the treatment time. For example, there was $99.77 \%$ (wt.\%) of Ir loaded on CF (Shanghai carbon works) by EDX analysis after immersing sample into a solution of $\mathrm{H}_{2} \mathrm{IrCl}_{6}$ for $2 \mathrm{~min}$. The heat treatment in the air at 450 ${ }^{\circ} \mathrm{C}$ for 15 min was performed before and after Ir coating. These steps were repeated eight times. The mechanism of this procedure could be explained by $\mathrm{H}_{2} \mathrm{IrCl}_{6}$ reaction at $450{ }^{\circ} \mathrm{C}$ to form $\mathrm{IrO}_{2}$ under atmospheric conditions, and the $\mathrm{IrO}_{2}$ reduction reaction also proceeded on the graphite fibres through (3-1) [58]:

$\mathrm{C}+\mathrm{IrO}_{2}=\mathrm{Ir}+\mathrm{CO}_{2}$

The Ir-material, when coated on the GF surface, could offer a better conductive and catalytic interface between the solution state and the solid state of the electrode, and a lower charge transfer. Much of the Ir metal was still covered with graphite fibres after 50 charge/discharge cycles in a vanadium redox cell, proving the high stability of the modified electrodes [58]. Similarly, bismuth nanoparticles were deposited on the felt by immersion in a $\mathrm{Bi}_{2} \mathrm{O}_{3}$ solution followed also by thermal reduction at $450{ }^{\circ} \mathrm{C}$ in air. Despite the low metal content (1 at.\%) on the surface of the fibers, the Bi-modified felt showed an excellent electrochemical improvement when an electrode was applied for vanadium redox flow battery [6]. After coating by $\mathrm{Bi}$, the charge transfer resistances for $\mathrm{V}^{2+} / \mathrm{V}^{3+}$ redox reaction on $\mathrm{CF}$ (Shanghai Q-Carbon Material Co., Ltd., China) and GF (GFD4.6, SGL Group, Germany) electrodes were decreased remarkably to 0.9 and $1.6 \Omega$, respectively (Figure $3-3$ ). This result confirmed strongly that the electron transfer between the felts electrodes and electrolytes was facilitated with the presence of Bi nanoparticles [20].

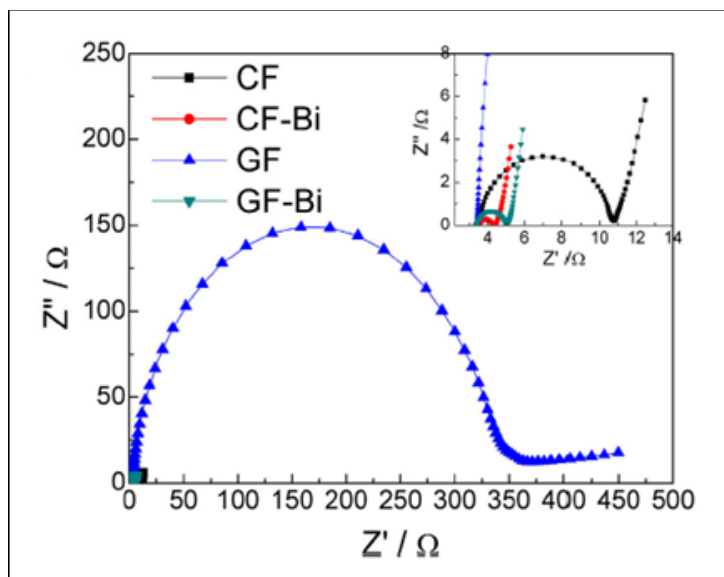

Figure 3-3. Electrochemical impedance spectroscopy of CF, CF-Bi, GF and GF-Bi in solution of $0.05 \mathrm{M} \mathrm{V}^{2+}$ and $0.05 \mathrm{M} \mathrm{V}^{3+}+3 \mathrm{M} \mathrm{H}_{2} \mathrm{SO}_{4}$. Reprinted from Ref. [20]. Copyright (2015), with permission from Elsevier. 
Furthermore, the growth up of metal materials on the surface of felts electrodes is performed by other treatments such as electrodeposition and thermal reduction. The electrodeposition of ruthenium oxide $\left(\mathrm{RuO}_{2}\right)$ films on the $\mathrm{CF}$ was conducted from a $\mathrm{RuCl}_{3}$ $(0.05 \mathrm{M})$ solution by applying a constant current density of $5 \mathrm{~mA} \mathrm{~cm}{ }^{-2}$ at room temperature [59]. By the same method, Pt particles were successfully coated on CF $(10 \times 10 \times 5 \mathrm{~mm})$ [60] or GF $(1 \times 2 \times 0.15 \mathrm{~cm})[4]$.

The high cost of noble metal catalysts limited their commercial application. To address this issue, studies focusing on less expensive metals have been performed as well. The electrochemical deposition of $\mathrm{PbO}_{2}$ on GF was carried out under an applied current of $50 \mathrm{~mA} \mathrm{~cm}^{-}$ 2 in cell containing $0.5 \mathrm{M} \mathrm{Pb}\left(\mathrm{NO}_{3}\right)_{2}$ in $0.1 \mathrm{M} \mathrm{HNO}_{3}$ solution. $\beta-\mathrm{PbO}_{2}$ with a tetragonal structure at the average crystal size of $0.5 \mu \mathrm{m}$ were well covered on felts fibres (Figure 3-4 a) after $30 \mathrm{~min}$ [61]. Similarly, the electrodeposition of $\mathrm{MnO}_{2}$ on the CF surface was also conducted in a twoelectrodes electro-chemical cell in $0.25 \mathrm{M}$ manganese acetate $\left(\mathrm{MnAc}_{2}\right)$ solution under applying a constant current of $8 \mathrm{~mA}$ for 10min [62]. Alternatively, thermal deposition of $\mathrm{Fe}(\mathrm{CO})_{5}$ was utilized to load Fe directly on GF (Sanye Carbon Co., Ltd., Beijing) in a sealed reactor made of glass (Figure 3-4 b). The temperature was controlled between 165 and $175^{\circ} \mathrm{C}$ for 3 min to completely decompose the $\mathrm{Fe}(\mathrm{CO})_{5}$. The generated $\mathrm{Fe}$ on the felt acted as catalysts in order to improve the electrochemical activity of the modified electrode. In particular, when it was applied as cathode for microbial fuel cells (MFCs), iron-doping increased the electron transfer efficiency, because iron coated on graphite felt was oxidized rapidly to iron oxide when it comes in contact with the solution in MFC and oxygen from the air. Electrons lost from iron on cathode were transferred to the anode. Consequently, the internal resistance of MFC using $\mathrm{Fe}$ modified cathodes was 1.8 times lower than pristine GF and shows higher power generation [63].

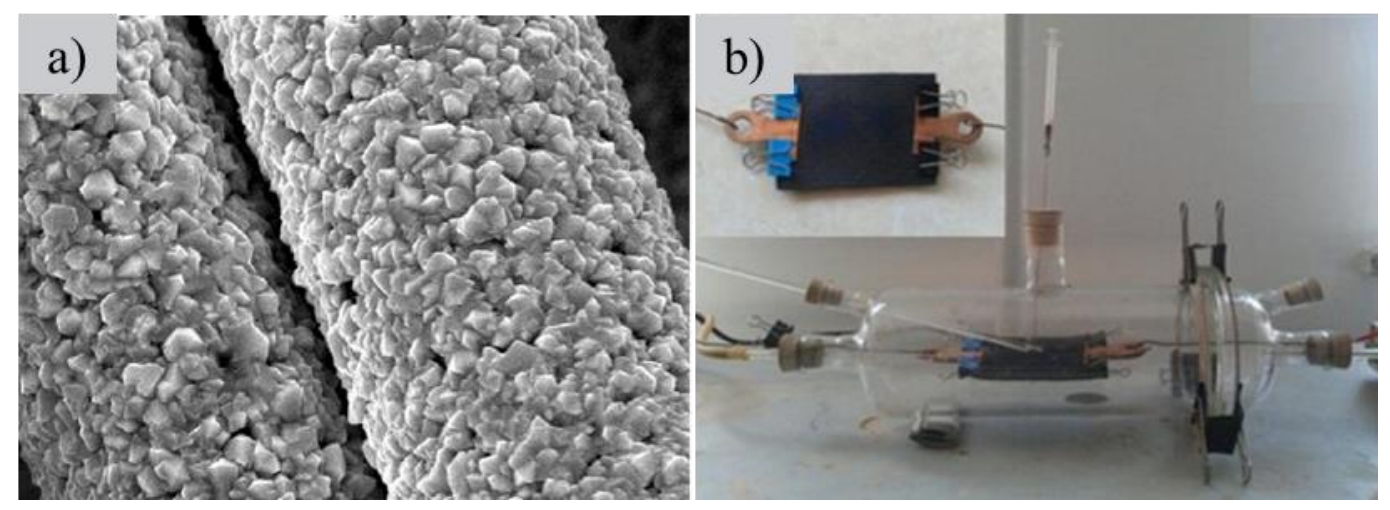


Figure 3-4. (a) SEM image of $\mathrm{PbO}_{2} / \mathrm{GF}$ [61] and (b) Reactor of deposition of $\mathrm{Fe}$ on GF. Reprinted from Ref. [63]. Copyright (2013), with permission from Elsevier.

\subsection{Graphene based modification}

In recent years, graphene has emerged as an exciting topic of research in materials science and condensed matter physics research. It has received extensive attention due to its remarkable electrical, physical, thermal, optical, high specific surface area and mechanical properties [64, 65]. Therefore, graphene was widely applicable for electrochemical activity of electrodes [66]. Different methods as dip-coating, constant potential technique and electrophoretic deposition (EPD) were used separately or combined together for the coating of graphene based materials on felts electrodes. For example, the coating of reduced graphene oxide (rGO) on CF (Shanghai Qijie Carbon Co., Ltd.) was performed using different steps: (1) graphene oxide (GO) suspension was prepared by using the sonication for $1 \mathrm{~h}$ to exfoliate the graphite oxide in water medium. (2) GO was loaded on the CF surface by the dipping-drying process in the prepared GO suspension. (3) The GO was then electrochemically reduced by applying a constant voltage of $-1.2 \mathrm{~V}$ in $0.5 \mathrm{M} \mathrm{Na}_{2} \mathrm{SO}_{4}$ electrolyte for $10 \mathrm{~min}$. By comparing the response of $\mathrm{CVs}$ curves in 0.5 $\mathrm{M} \mathrm{Na}_{2} \mathrm{SO}_{4}$ solution, the $\mathrm{rGO} / \mathrm{CF}$ electrode (Figure 3-5 a, d) has a higher current density than the bare $\mathrm{CF}$ in the voltage range from -0.6 to $0.6 \mathrm{~V}$, suggesting a larger electrode surface area and better conductivity after modification [62].

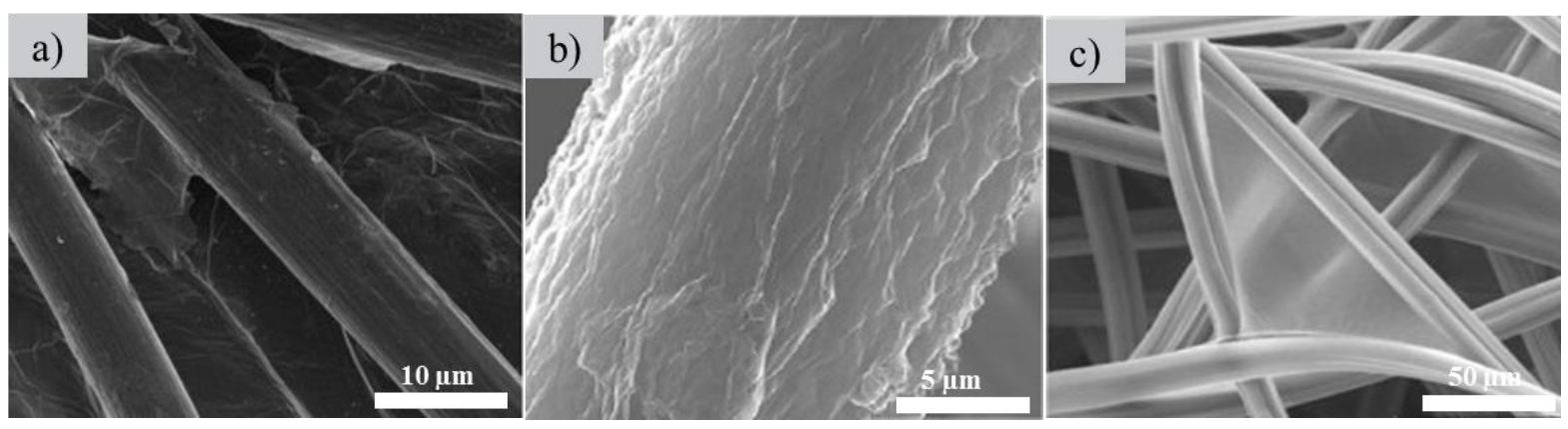



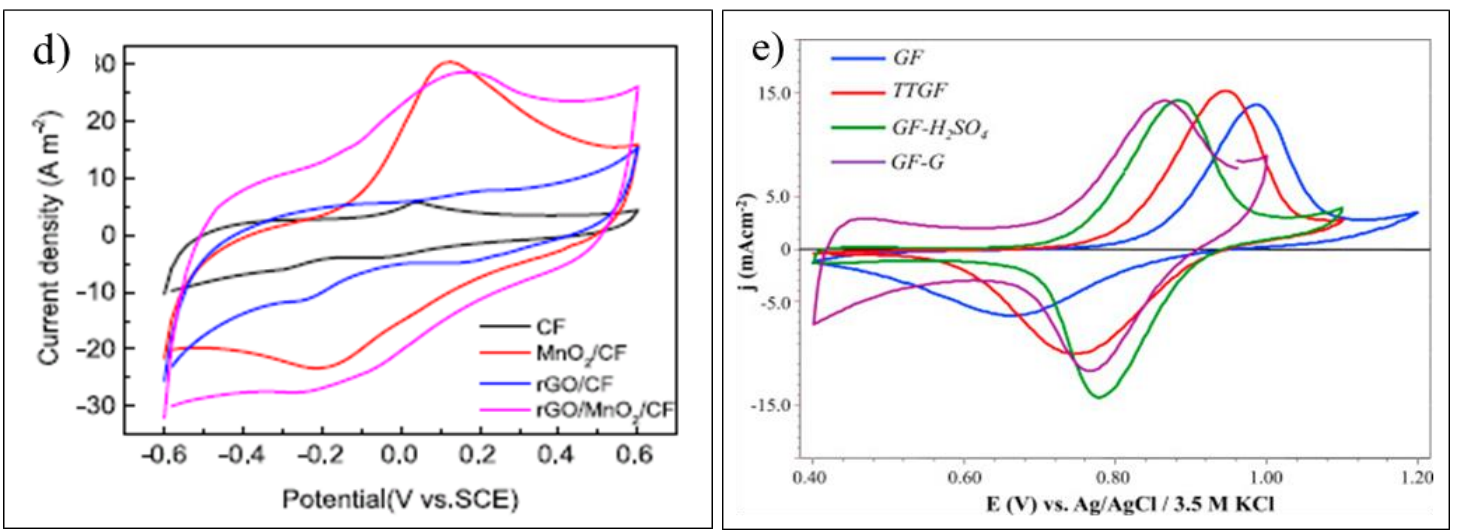

Figure 3-5. SEM images of rGO coated on (a) CF (Shanghai Qijie Carbon Co., Ltd.); (b,c) GF (RVG-2000, Carbon-Lorraine company); (d) CVs curves of the CF in $0.5 \mathrm{M} \mathrm{Na}_{2} \mathrm{SO}_{4}$ solution at a scan rate of $10 \mathrm{mV} \mathrm{s}^{-1}$ and (e) CVs of the various GF electrodes recorded in solution (1.0 $\mathrm{M} \mathrm{H}_{2} \mathrm{SO}_{4}$ ) containing 0.05 $\mathrm{M} \mathrm{VOSO}_{4}$ (Scan rate of $1 \mathrm{mV} \mathrm{s}^{-1}$ ). Reprinted from Ref. [62, 67]. Copyright (2016), with permission from Elsevier.

In addition, the EPD shows several advantages for obtaining homogeneous film on felts electrode from suspensions containing well-dispersed charged particles like GO solution, with high deposition rates, simple operation, easy scalability and all that by avoiding the use of binders [68]. A graphene-modified GF (GF-G) was synthesized using EPD technology from GO suspensions in two-electrodes cell. By applying a voltage of $10 \mathrm{~V}$ for $3 \mathrm{~h}$, the negative GO sheets were moved towards the positive GF electrode. The GF-G showed graphene-like sheets deposited on the surface of the felts either in a wrinkled configuration (Figure 3-5 b) or anchored between them (Figure 3-5 c). The amount of oxygen declined from 13 at. $\%$ in the initial GO to 3.84 at. $\%$ proved that GO was partially reduced. To compare with other modification methods, the chemical treatment by electrochemical oxidation in $1 \mathrm{M} \mathrm{H}_{2} \mathrm{SO}_{4}\left(\mathrm{GF}_{-} \mathrm{H}_{2} \mathrm{SO}_{4}\right)$ during $3 \mathrm{~h}$ or thermal treatment at $450{ }^{\circ} \mathrm{C}$ with the same time, $3 \mathrm{~h}$, under an air flow in a tubular furnace (TTGF) were done. As could be seen clearly from Figure 3-5 e, the electrochemical performance of graphene modification was even higher than $\mathrm{GF}-\mathrm{H}_{2} \mathrm{SO}_{4}$ or TTGF. Because of the excellent electrochemical properties of graphene based materials, they are still a promising future for applications in the modification of $\mathrm{CF}$ electrodes. 


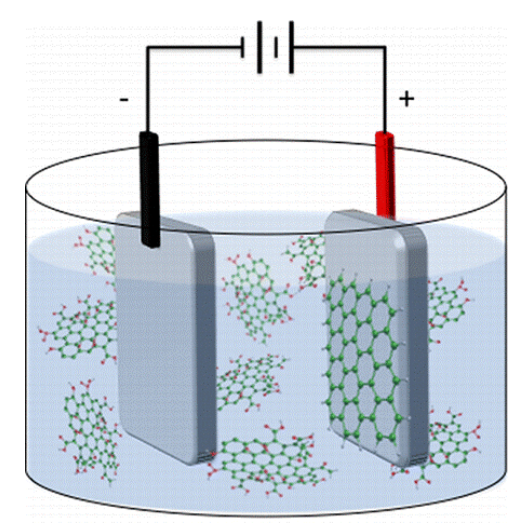

Figure 3-6. EPD of graphene on CF electrodes. Reprinted from Ref. [68]. Copyright (2013), with permission from ACS Publications.

\subsection{Carbon nanotubes based modification}

CNTs have been attractive for the modification of felts electrodes because of their mechanical flexibility, excellent electrical and thermal conductivities, and significantly large surface area [69]. The coating of single-walled carbon nanotube (SWCNT) was performed by simple way where CF was immersed into the SWCNT suspension. The CF was then dried at 80 ${ }^{\circ} \mathrm{C}$ for $5 \mathrm{~h}$. The SWCNT (2 wt\% relative to the amount of $\mathrm{CF}$ ) was ultrasonically dispersed previously in N,N-dimethyl formamide (DMF). The process was repeated until all the SWCNT suspension adsorbed into the CF. The modified electrode showed a better catalytic performance with higher electron transfer rate [70]. In the other hand, the CNTs could be directly grown on the surface of felts by chemical vapor deposition (CVD) method. This technique does not require a binder. The felts sample was placed in the center of a quartz tube and heated at high temperature (around $800{ }^{\circ} \mathrm{C}$ ) under Ar gas flow, followed by the injection of the carbon precursor source. Toluene or ethylenediamine was applied as source solution for growth of CNTs or nitrogenCNTs on GF (Figure 3-7 a, b). Thanks to the small size $(\sim 30 \mathrm{~nm})$ of CNTs, they created a significant increase of the electrochemical surface area of the felt materials. In addition, the Ndoping could further improve the electrode performance because of the modified electronic and surface properties of CNTs on GF [71]. The CNTs/CF electrode was also obtained by growing CNTs via CVD of methanol on cobalt and manganese metallic particles deposited on CF. The $\mathrm{S}_{\mathrm{BET}}$ of CF loaded with $37.8 \mathrm{mg}$ of CNTs was found to be 148 times higher than the $1 \mathrm{~m}^{2} \mathrm{~g}^{-1}$ for non-modified one [32]. 

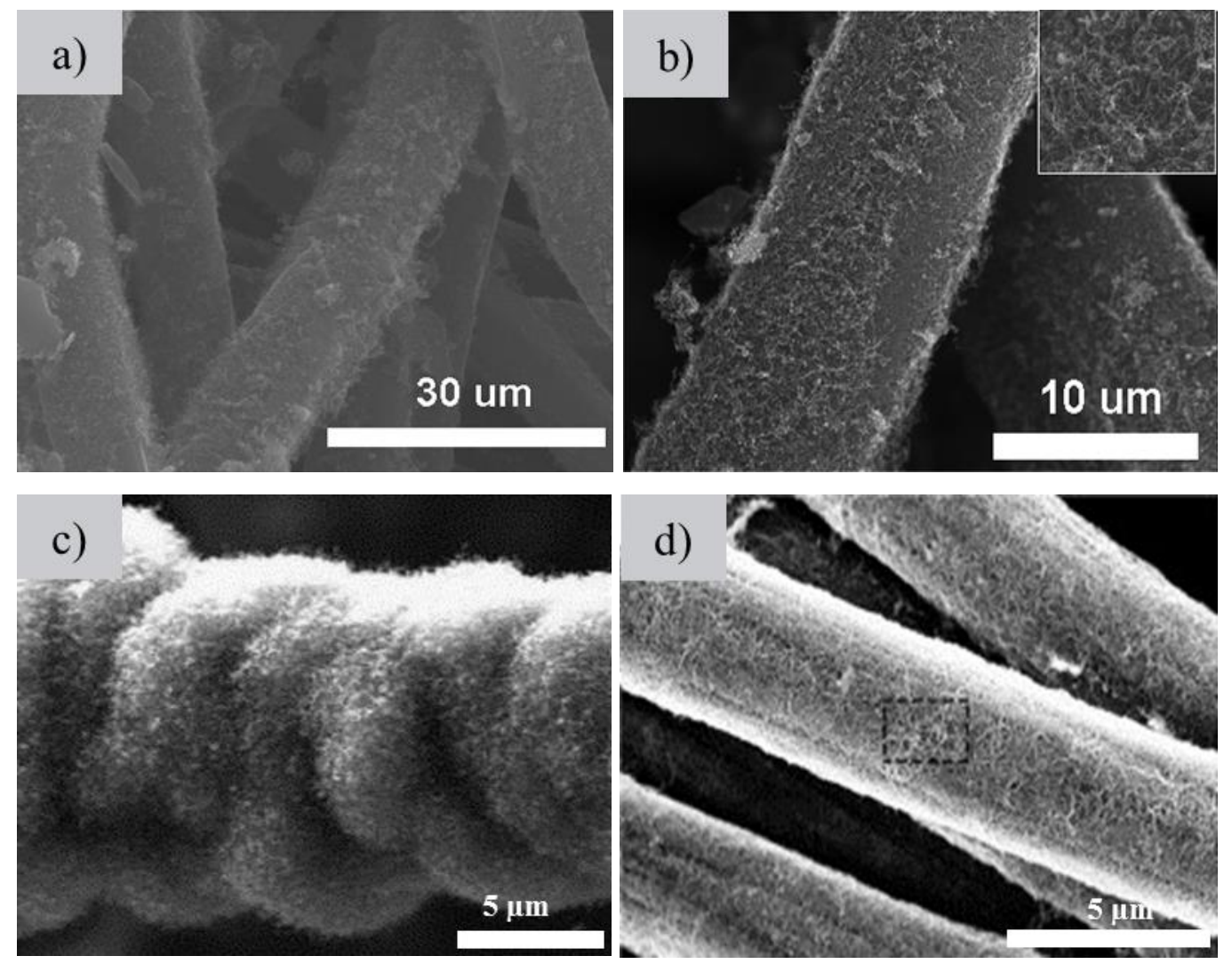

Figure 3-7. SEM images of (a) CNTs grown on GF, (b) N-CNTs grown on GF, (c) CNTs on CF by CVD, and (d) CNTs on CF by EPD. Reprinted from Ref. [71], [72], and [73]. Copyright (2006, 2012, 2014), with permission from ACS Publications and Elsevier.

The CVD is continuously an efficient technique for growth of multi-walled carbon nanotubes (MWCNTs) on CF. The used precursor was a mixture of $\mathrm{Fe}\left(\mathrm{C}_{5} \mathrm{H}_{5}\right)_{2} / \mathrm{C}_{7} \mathrm{H}_{8}$ in which the ferrocene concentration in the toluene solution was fixed at $20 \mathrm{~g} \mathrm{~L}^{-1}$. The CNTs with high aspect ratio were grown from the iron sites. These irons species were produced from the decomposition and the subsequence nucleation of the iron species from the ferrocene precursor deposited on the CF substrate. Both mechanical strength and electrical conductivity enhancement with the effective surface area were recorded with the modification. The CNTs loading allows reaching $150 \mathrm{~m}^{2} \mathrm{~g}^{-1}$ surface area for a CNTs weight intake of $98 \%$. The surface of the vertically aligned CNTs presented residual iron was removed by an acid treatment $\left(\mathrm{HNO}_{3}, 65 \%\right.$, at $80{ }^{\circ} \mathrm{C}$ for $\left.2 \mathrm{~h}\right)$ which led to oxygenated functional groups [41]. Other CNTs/CF electrodes were prepared using the decomposition of methanol on different metallic catalysts, including cobalt, manganese and lithium, supported on CF [72]. The SEM revealed that the CNTs on the CF electrode have a structure that could be recognized as bamboo-like (Figure 3-7 c), which was independent of the diameter in good agreement with the study of Rosolen et al. [74]. 
Beside CVD, EPD shows noticeable advantages as a low-cost and simple method [75, 76]. Before doing EPD, CNTs were dispersed in isopropyl alcohol using ultrasonic bath for $3 \mathrm{~h}$ to get a dispersion of $1.6 \mathrm{~g} \mathrm{~L}^{-1}$. Around $1.05 \mathrm{wt} \%$ CNTs were uniformly deposited on CF without obvious agglomeration or acutely curly body (Figure 3-7 d), by applying a constant voltage of $40 \mathrm{~V}$ for $1 \mathrm{~min}$ [73]. The studies have been enlarged to utilize as well CNTs anchoring functional groups like carboxyl and hydroxyl. The carboxyl MWCNTs were adhered onto the CF (Shenhe Carbon Fibre Materials Co. Ltd, thickness $4 \mathrm{~mm}$ ) by immersing in a mixture solution of COOHMWCNTs and $0.02 \mathrm{wt} \%$ Nafion under ultrasonication for $10 \mathrm{~min}$. In this case, using Nafion as a binder guarantees the stability of the MWCNTs/CF electrode. Due to the carboxyl groups on the MWCNTs, the hydrophilic ability of the CF was improved and more active sites were introduced [77]. Similarly, the COOH-MWCNTs were ultrasonically dispersed in dimethyl formamide and then the $\mathrm{CF}$ was immersed in this solution. $\mathrm{COOH}-\mathrm{MWCNTs} / \mathrm{CF}$ was obtained by drying the electrode in the oven at $100{ }^{\circ} \mathrm{C}$ for $24 \mathrm{~h}$ [78].

\subsection{Carbon nanofiber based modification}

Among modifications performed by carbon nanomaterials, carbon nanofibers (CNFs) appear to be a promising candidate, owing to their unique electrical, physico-chemical and mechanical properties $[79,80]$. One of efficient and low cost technique which was proposed to produce CNFs was the CCVD (Catalytic Chemical Vapor Deposition) from gases containing carbon. The growth of CNFs on CF (Figure 3-8) was conducted by support of nickel (Ni) catalyst. Firstly, Ni was deposited onto the CF surface via an incipient wetness impregnation of a solution of nickel nitrate. The calcination and reduction was necessary afterward to change nickel salt to nickel metal. The CNFs was grown on CF by CVD under flow of a mixture of $\mathrm{C}_{2} \mathrm{H}_{6} / \mathrm{H}_{2}$ (40:60, v/v \%) from $400{ }^{\circ} \mathrm{C}$ to $680{ }^{\circ} \mathrm{C}$. CNFs modification showed a lower surface area for the same weight of carbon intake at $98 \mathrm{wt} . \%$, with $80 \mathrm{~m}^{2} \mathrm{~g}^{-1}$ instead of $150 \mathrm{~m}^{2} \mathrm{~g}^{-1}$ for CNTs. However, this value was significant in comparison to pristine electrode $\left(1 \mathrm{~m}^{2} \mathrm{~g}^{-1}\right)$ [41]. Moreover, Ni catalyst on GF (Shanghai Xinxing Carbon Co.) was formed from reduction of nickel nitrate by a mixture of $\mathrm{H}_{2} / \mathrm{Ar}\left(1: 3(\mathrm{v} / \mathrm{v})\right.$, flow rate $\left.160 \mathrm{~mL} \mathrm{~min}^{-1}\right)$ at $600{ }^{\circ} \mathrm{C}$ for $3 \mathrm{~h}$. After that, a growth of CNFs on the GF was accomplished at the same temperature in a flow of $\mathrm{C}_{2} \mathrm{H}_{4} / \mathrm{H}_{2}\left(2: 1\right.$ (v/v), flow rate $\left.60 \mathrm{~mL} \mathrm{~min}^{-1}\right)$. The compressive strength of CNFs/GF increased with the increase of the CNFs amount from 5\% to 50\% [81]. This method was utilized for the CNFs modification of both GF provided by Shanghai Qijie Carbon Material Co., Ltd. [82] or GF provided by Carbone Lorraine Co [83]. 

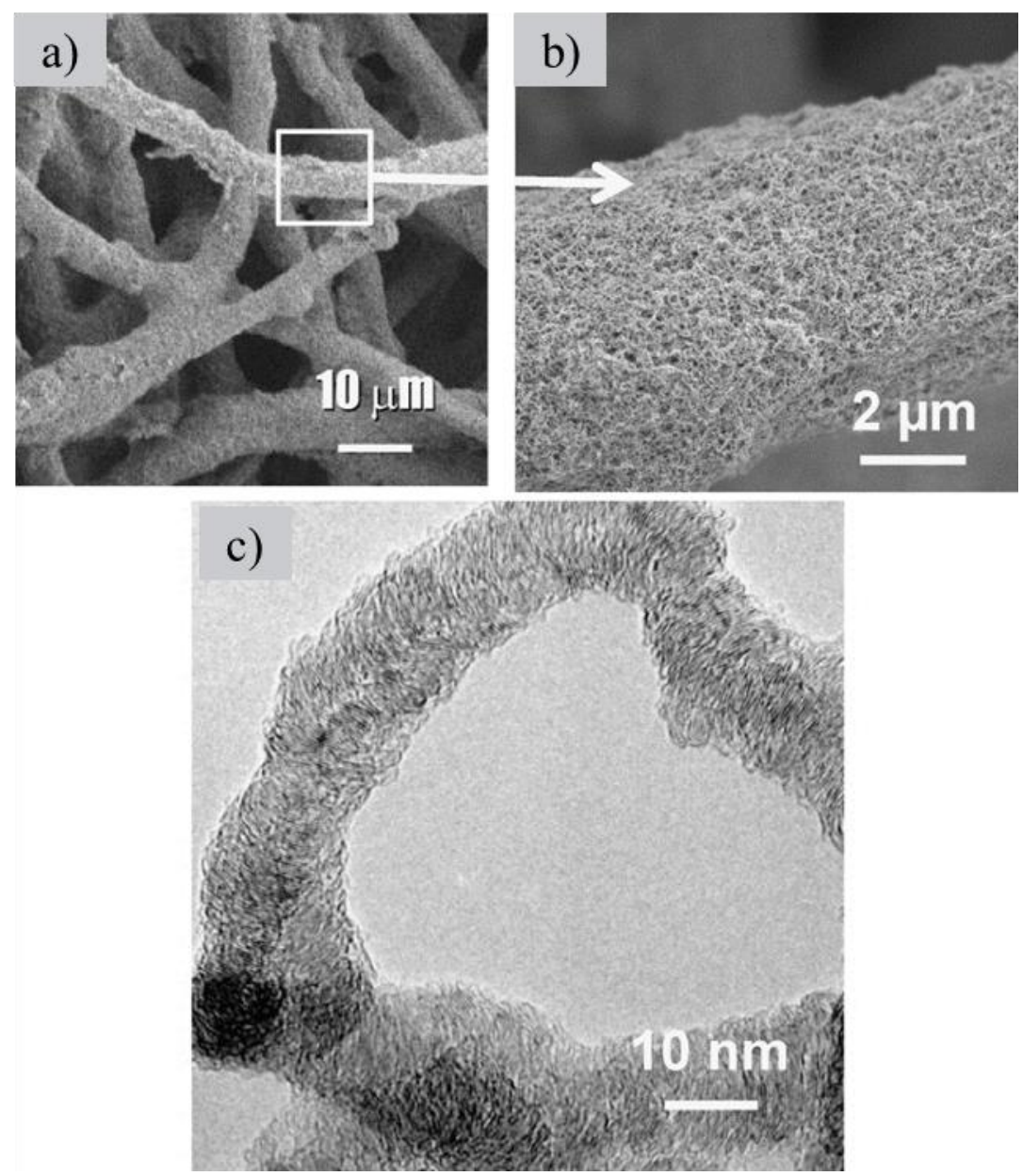

Figure 3-8. (a, b) SEM images and (c) high-resolution TEM (HR-TEM) of CNFs on CF. Reprinted from Ref. [41]. Copyright (2011), with permission from Elsevier.

Microwave-assisted method is a simple and fast technique for the CNFs modification on $\mathrm{CF}$. This method relates to the usage of microwave irradiation that can heat $\mathrm{CF}$ substrates to several hundred degree Celsius within a very short time (few minutes or even of just seconds) [84]. The synthesis approaches are similar to the CVD method for synthesis of CNFs, but it can decrease the processing times remarkably $[85,86]$. The modification process on GF (GFA6, $S G L$ Carbon, thickness $6 \mathrm{~mm}$ ) was performed in subsequent steps like CVD. The full power (1400 W) of the microwave was applied for 5 to $10 \mathrm{~min}$ and repeated two more times to enable further CNFs growth. By the in-situ growth of CNFs, the active surface identified by the electrochemical double layer capacities of the modified electrode was 50 times higher than non-modified one [87]. 


\subsection{Polymer based modification}

Polyaniline (PANi) and polypyrrole (PPy) are the most common conducting polymers for electrode modification because of their high electrical conductivity, ease of preparation, and environmental stability $[88,89]$. The coating of conductive polymer film on the surface of $\mathrm{CF}$ is usually conducted by the electropolymerization process in solution containing monomers. Interestingly, electropolymerized materials have unique properties which are not peculiar to the corresponding monomers [90, 91]. The pyrrole (PPy)/ anthraquinone-2,6-disulfonat (AQDS) conductive film was coated on CF (Liaoyang Jingu Carbon Fiber Sci-Tech Co., Ltd., China) (Figure 3-9 c) in a three electrodes electrochemical cell. The polymer film was formed on the CF surface by applying a constant potential of $0.8 \mathrm{~V}$ vs SCE and its thickness was controlled by the charge passed to the working electrode. The modified electrode pointed out a larger current response in comparison with the unmodified electrode in the scan range between $-1 \mathrm{~V}$ to $0.6 \mathrm{~V}$ on CVs (Figure 3-9 e). This is the result of the enhanced surface area and conductivity of the PPy/AQDS-modified electrode [92]. Beside that, three kinds of phenothiazies including Thionine $(\mathrm{TN})$, Toluidine Blue (TB) and Methylene Blue (MB) were investigated in order to deposit poly(pheniothiazine) films on CF (Nihon Carbon Co., Ltd., Japan, thickness 3mm) electrode surface. High electrocatalytic activity for the oxidation of nicotinamide adenine dinucleotide reduced form $(\mathrm{NADH})$ at $+0.2 \mathrm{~V}$ vs. $\mathrm{Ag} / \mathrm{AgCl}$ was monitored on the poly(TB) film-modified $\mathrm{CF}$ [91]. Beside electropolymerization method, the polymer modified-felts could be prepared in a simple way by submerging $\mathrm{CF}$ in $\mathrm{HCl}$ solution adding aniline monomer and ammonium persulfate. The polymerization was conducted during $8 \mathrm{~h}$ by continuously stirring in order to coat PANi on the surface of CF [93].

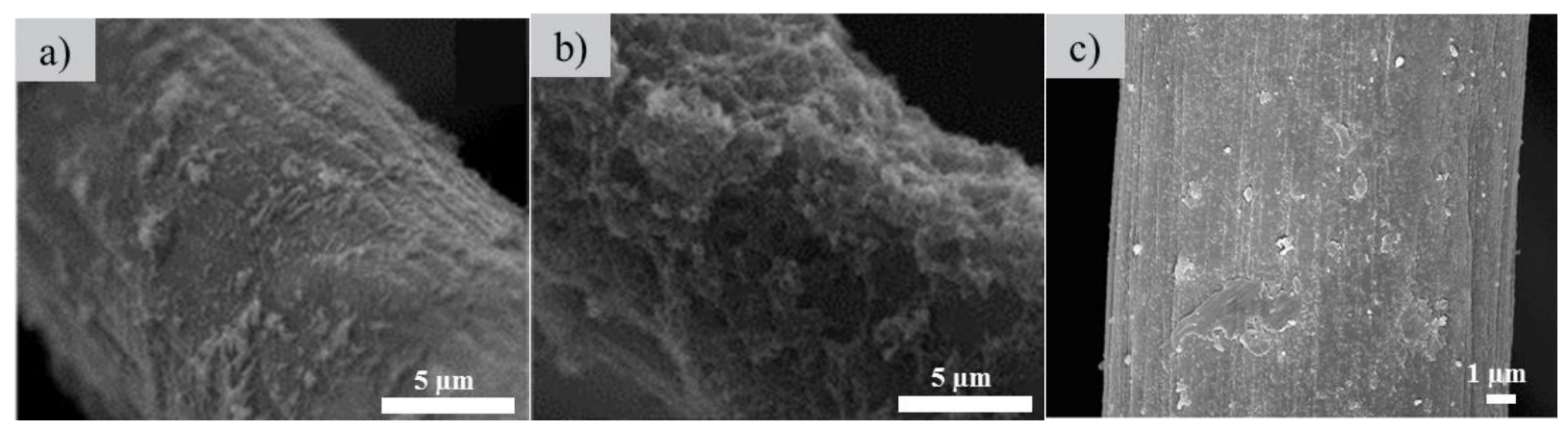



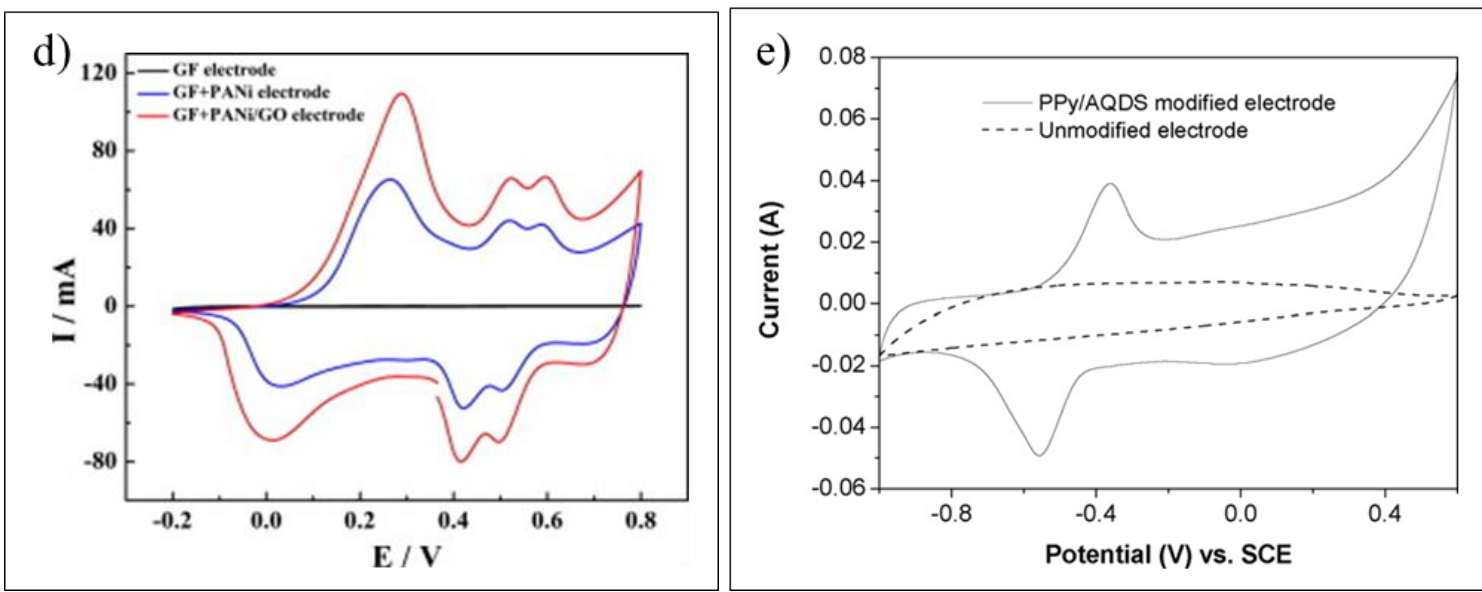

Figure 3-9. SEM images of (a) PANi/GF; (b) PANi/GO-GF, (c) PPy/AQDS-CF; CVs of the modified electrodes in (d) $1.0 \mathrm{M} \mathrm{H}_{2} \mathrm{SO}_{4}$ solution (Scan rate of $5 \mathrm{mV} \mathrm{s}^{-1}$ ), and (e) $0.1 \mathrm{M}$ phosphate buffered solution ( $\mathrm{pH}$ 7.0) (Scan rate of $10 \mathrm{mV} \mathrm{s}^{-1}$ ). Reprinted from Ref. [92, 94]. Copyright (2010, 2015), with permission from Elsevier.

In order to improve the physicochemical and electrochemical properties of the conducting polymers, many copolymers were prepared and investigated. The electrochemical activity of poly(aniline-co-o-aminophenol) was about four times as high as that of PANi in $0.3 \mathrm{M} \mathrm{Na}_{2} \mathrm{SO}_{4}$ solution of $\mathrm{pH}$ 5. The copolymer had a good stability and a high reversibility [95]. A poly(aniline-co-o-aminophenol) film with average mass of $1.17 \pm 0.1 \mathrm{~g}$ was deposited on CF by Cui et al. through electrochemical synthesis in solution containing simultaneously aniline and $o$ aminophenol [96]. What's more, the biocompatibility of felts electrodes was increased significantly when they were coated by the co-polymers containing nitrogen/oxygen functional groups. The hydrophilic conductive co-polymers like poly (aniline-co-o-aminophenol), poly (aniline-co-2, 4-diaminophenol), poly (aniline-1, 8-diaminonaphthalene) acted as a redox mediator improving the electron transfer from the $\mathrm{CF}$ to bacteria as discussed later in MFCs applications [93]. In terms of the increase of surface area, electronic conductivity, biocompatibility and stability, PPy was simultaneously covered on the GF (Beijing Sanye Co.Ltd, thickness 5mm) with GO. The composite of PPy/GO was grown up on the surface of GF electrode by one-step electro-synthesis way where the electropolymerization of PPy was carried out in a solution including simultaneously GO and pyrrole monomers (Figure 3-10). The oxygencontaining functional groups of GO could plays the role like external dopant for PPy. The new electrode exhibited improved performance compared with PPy alone when it could increase significantly the power density of MFCs [97]. In order to overcome the unsatisfactory stability of PANi modified GF electrode, GO was introduced into PANi/GO composite for the modification 
of graphite (Chemshine Carbon CO., China) by an electrochemical approach [98]. The PANi/GO-GF (Figure 3-9 b, d) enhanced outstandingly the electrochemical activity as well as the hydrophilicity of GF electrode. After $1000 \mathrm{~s}$, the stability of the modified electrode was actually noticeable (Figure 3-9 a) because of the synergistic effect of PANi and GO [94]. Moreover, conductive polymers have been combined with CNTs to increase the effective surface area and the electrical conductivity of the resulting material. The PANi was electropolymerized on the surface of GF (Beijing Sanye Carbon, China, thickness $4 \mathrm{~mm}$ ) followed by the EPD of CNTs [99]. Using polymer for the modification of GF electrode is convenient and effective method because it is low-cost approach and improves the electrochemical performance. Modifications such as the above have been extensively used to prepare composite electrodes for capacitive systems for the improvement of capacity storage which makes them promising routes for energy applications.

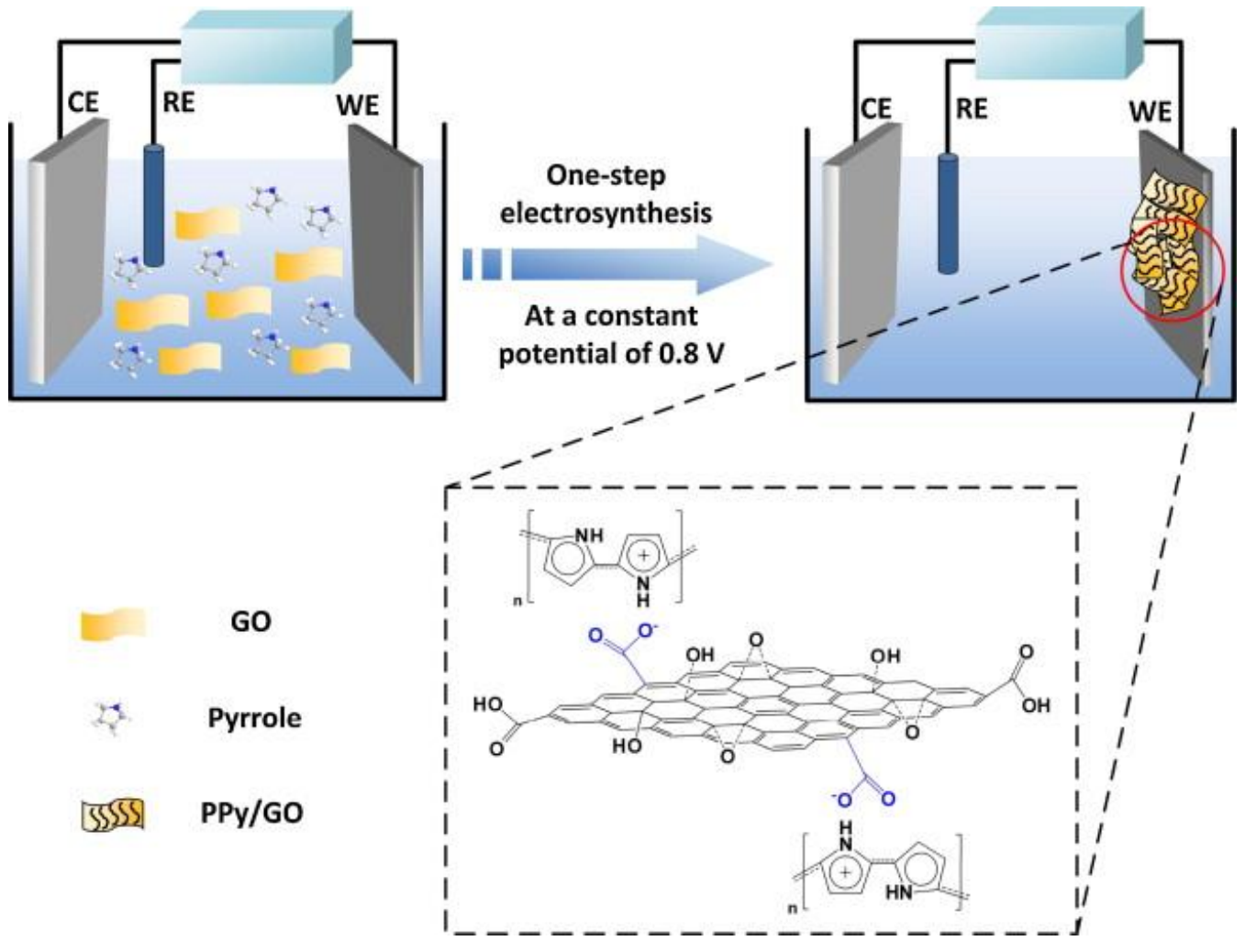

Figure 3-10. The schematic diagram of the one-step electrosynthesis of PPy/GO composites on GF. Reprinted from Ref. [97]. Copyright (2013), with permission from Elsevier. 


\subsection{Zeolites based modification}

Zeolites are porous crystalline aluminosilicates of $\mathrm{SiO}_{4}{ }^{4-}$ and $\mathrm{AlO}_{4}{ }^{5-}$ tetrahedra connected by oxygen bridges. Zeolite-modified electrodes (ZMEs) have numerous applications in various fields especially in electroanalytical [100]. Hydrothermal synthesis is a basic technique to grow zeolite. For example $\mathrm{NaX}$ zeolite was grown up at $100{ }^{\circ} \mathrm{C}$ for $3 \mathrm{~h}$ in solution containing sodium silicate, sodium aluminate, and sodium hydroxide with a molar composition of $3.5 \mathrm{Na}_{2} \mathrm{O}: 1$ $\mathrm{Al}_{2} \mathrm{O}_{3}: 2.1 \mathrm{SiO}_{2}: 1000 \mathrm{H}_{2} \mathrm{O}$ (Figure 3-11 a). It could be seen clearly from Figure 3-11 d that the GF modified with $\mathrm{NaX}$ showed a higher electrochemical activity after ex-situ acclimatization in presence of bacterial in comparison to bare electrodes which proved the interest of the approach for bio-electrodes preparation and used in microbial biofuel cell [101, 102].
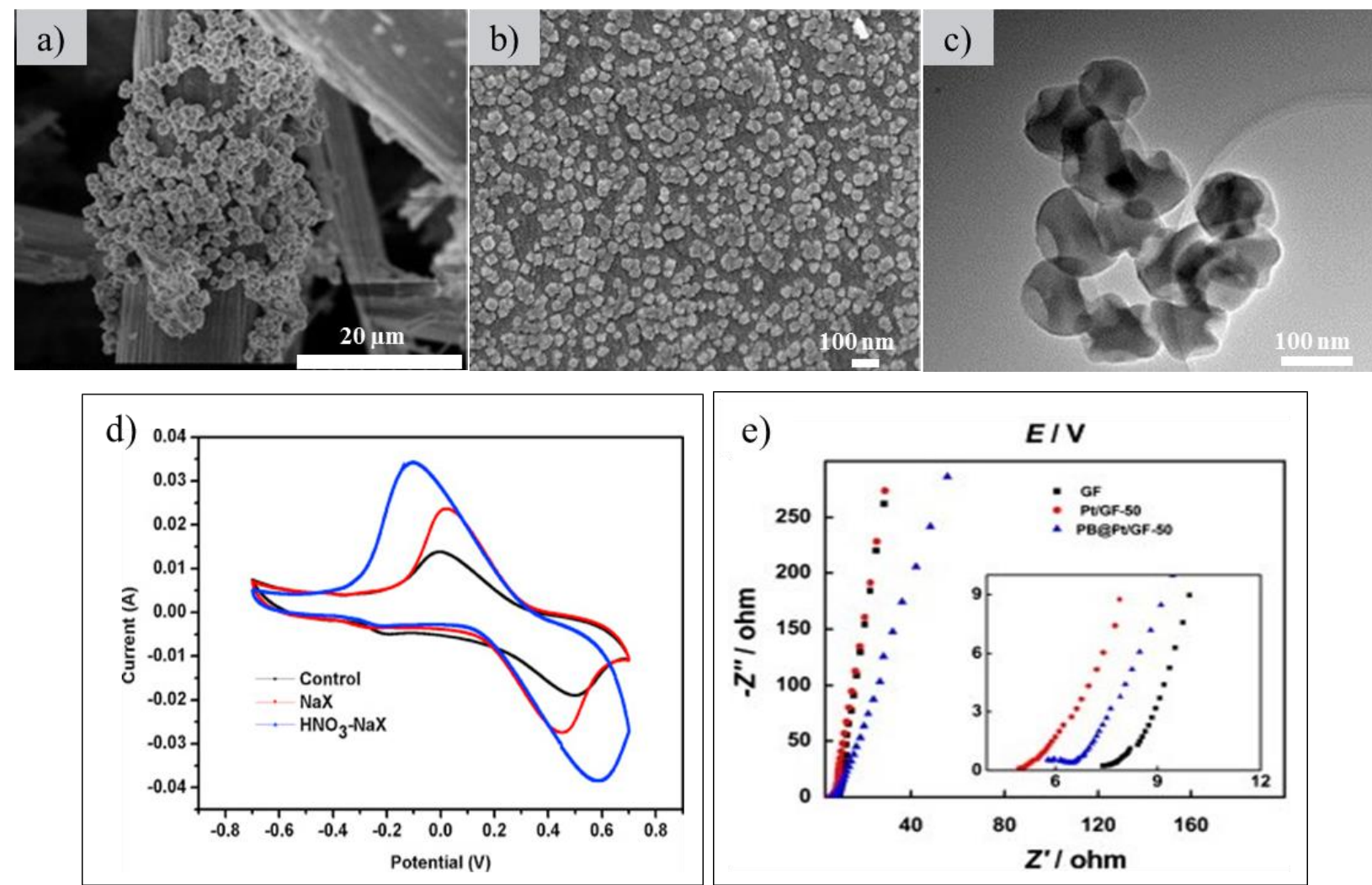

Figure 3-11. SEM images of (a) $\mathrm{HNO}_{3}-\mathrm{NaX} / \mathrm{GF}$, (b) $\mathrm{PB} @ \mathrm{Pt} / \mathrm{GF}$, (c) TEM image of PB nanoparticles, (d) CVs of the three GF electrodes at the end of the ex-situ acclimatization (vs. $\mathrm{Ag} / \mathrm{AgCl}$, scan rate of $5 \mathrm{mV} / \mathrm{s}$ ranging from $-700 \mathrm{mV}$ to $+700 \mathrm{mV}$ ), and (e) Nyquist plots of GF, Pt/GF-50 and PB@Pt/GF electrodes in $0.5 \mathrm{M} \mathrm{KCl}$ aqueous solution. Reprinted from Ref. [4, 101]. Copyright (2013, 2016), with permission from Elsevier. 
Another kind of zeolite named as Prussian blue (PB, ferric hexacyanoferrate) is also of interest for electrode modification [103, 104], which was reported by Neff et al. for the first time in 1978 [105] PB electrochemical properties. Electrochromic [106], electrochemical [107], photophysical [108], as well as molecular magnetic properties [109] were shown some years later. The PB modification was conducted via a chemical deposition process on an electrochemically Pt modified CF. The Pt/GF electrode was firstly submerged in a solution of $1.0 \mathrm{mM} \mathrm{FeCl}_{3}, 1.0 \mathrm{mM} \mathrm{K}{ }_{3} \mathrm{Fe}(\mathrm{CN})_{6}, 0.1 \mathrm{M} \mathrm{KCl}$ and $0.025 \mathrm{M} \mathrm{HCl}$ during $60 \mathrm{~min}$, then washed with deionized water and dried. The SEM images of the as prepared PB@Pt/GF (Figure 3-11 b) showed clearly the three-dimensional hierarchical macroporous open-pore structure, proving the successful deposition of PB (Figure 3-11 c) on the GF. As observed on Figure 3-11 e, the Pt/GF, $\mathrm{PB} @ \mathrm{Pt} / \mathrm{GF}$, and GF electrodes showed their magnitude of solution resistances at $4.94 \Omega$, $5.72 \Omega$, and $7.38 \Omega$, respectively. An excellent stability was demonstrated after more than 100 consecutive voltammetric cycles in $0.5 \mathrm{M} \mathrm{KCl}$ solutions [4]. In the other hand, GF electrode was modified by a novel PB and ionic liquid 1-butyl-3-methylimidazolium tetrafluoroborate ([Bmim] $\left[\mathrm{BF}_{4}\right]$ ) via simple method involving GF placed in a ultrasound bath of $[\mathrm{Bmim}]\left[\mathrm{BF}_{4}\right]$ and then in a PB precursor solution. PB nanoparticles anchoring was improved on the surface of the GF because of the use of the ionic liquid.

CF was recently modified by Zeolitic Imidazolate Framework (ZIF-8) starting from an Atomic Layer Deposition (ALD) of Zinc Oxide ( $\mathrm{ZnO}$ ), its subsequent solvothermal conversion to ZIF-8 and heat treatment under control atmosphere. Both the electrocatalytic properties and the electroactive surface area were improved. The specific surface area of the CF was increased from $0.0915 \mathrm{~m}^{2} \mathrm{~g}^{-1}$ to $64 \mathrm{~m}^{2} \mathrm{~g}^{-1}$ for raw and modified CF, respectively [110].

\section{Energy applications of CF-based electrodes}

\subsection{Introduction}

In this section, the application of CF- based electrodes in energy field will be discussed, consisting of vanadium redox flow batteries, BFCs, MFCs, capacitors, electrochemical solar energy and Li-ion batteries. The operability of the modified electrodes is evident through the comparison with bare electrodes in each issue. Additionally, the felts electrodes produced by different companies or modification methods will be collated and collected for a multidimensional overview about this material. 


\subsection{Vanadium redox flow batteries}

Vanadium redox flow batteries (VRFB) have been known as one of the most promising candidates for energy storage applications. VRFB consists of two half-cells separated by a membrane and equipped of carbon electrodes. The positive half-cell is filled by the mixture $\mathrm{V}(\mathrm{IV}) / \mathrm{V}(\mathrm{V})$ whereas the negative half-cell is a mixture of $\mathrm{V}(\mathrm{II}) / \mathrm{V}(\mathrm{III})$ both in acid solution [111, 112]. Carbon and graphite felts-based materials were selected as the most suitable electrodes for both the positive and negative half-cells in the VRFB because of their three-dimensional network structures and specific surface area, as well as high conductivity and chemical and electrochemical stability [10,113, 114]. Figure 4-1 shows the components of a half-cell in a stack where the electrochemical reaction of vanadium ions occurs on the fiber surface. Stacks are composed of multiple cells in series. The voltage is linked to the number of stacks while current output is determined by the area of the electrodes. To upgrade the power density and to decrease the size and the cost of a VRFB, it is necessary to develop high-performance of felts electrodes relevant to the electrocatalytic activity, the conductivity, the hydrophilicity and the pore structure [48]. The electron transfer between electrolyte and the felts electrodes was accelerated strongly after the modification which led to the increase of the electrochemical activity of the $\mathrm{VO}_{2}{ }^{+} / \mathrm{VO}^{2+}$ redox couple in VRFB [51]. Table 4-1 summarizes the activity and the efficiency of the VRFB using non-modified and modified felts electrodes.

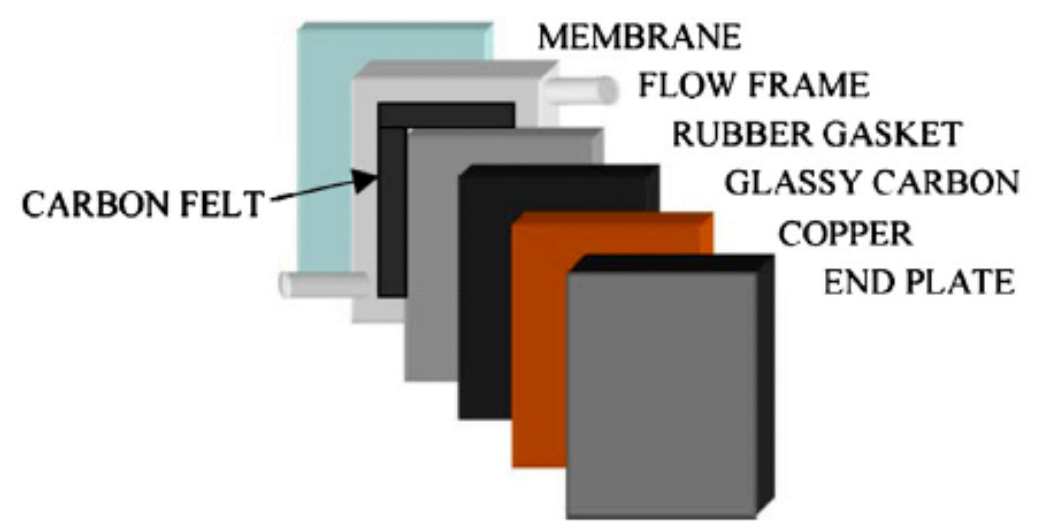

Figure 4-1: Components of a VRFB stack using CF. Reprinted from Ref. [115]. Copyright (2006), with permission from Elsevier. 
Table 4-1. The activity and the efficiency of the VRFB using graphite \& carbon felt-based electrodes.

\begin{tabular}{|c|c|c|c|c|c|c|c|c|c|}
\hline \multicolumn{2}{|c|}{ Electrode material } & $\begin{array}{c}\text { Electrode } \\
\operatorname{area}\left(\mathbf{c m}^{2}\right)\end{array}$ & $\begin{array}{c}\text { Membrane } \\
\text { material }\end{array}$ & $\begin{array}{l}\text { Employed } \\
\text { solutions }\end{array}$ & $\begin{array}{l}\text { Current } \\
\text { density }\end{array}$ & $\begin{array}{l}\text { Coulombic } \\
\text { efficiency }\end{array}$ & $\begin{array}{l}\text { Voltage } \\
\text { efficiency }\end{array}$ & $\begin{array}{l}\text { Energy } \\
\text { efficiency }\end{array}$ & Ref. \\
\hline \multirow{2}{*}{$\begin{array}{c}\text { Rayon- } \mathrm{GF}^{\mathrm{a}} \text { (thick } \\
3 \mathrm{~mm})\end{array}$} & The pristine & \multirow{4}{*}{$25 \mathrm{~cm}^{2}$} & \multirow{4}{*}{$\begin{array}{l}\text { CMV (Asahi } \\
\text { Glass Co., } \\
\text { Japan) }\end{array}$} & \multirow{4}{*}{$\begin{array}{c}2 \mathrm{M} \mathrm{V}(\mathrm{V}) \text { in } 4 \mathrm{M} \\
\mathrm{H}_{2} \mathrm{SO}_{4} \text { and } 2 \mathrm{M} \\
\mathrm{V}(\mathrm{II}) \text { in } 3 \mathrm{M} \mathrm{H}_{2} \mathrm{SO}_{4} \\
\text { for the positive } \\
\text { and negative half- } \\
\text { cells }\end{array}$} & \multirow{4}{*}{40} & 96.0 & 77.3 & 74.2 & \multirow{2}{*}{$\begin{array}{l}1993 \\
{[19]}\end{array}$} \\
\hline & $\begin{array}{c}\text { Thermal } \\
\text { treatment }(400 \\
\left.{ }^{\circ} \mathrm{C} \text {, Air }\right)\end{array}$ & & & & & 98.2 & 87.2 & 86.0 & \\
\hline \multirow[b]{2}{*}{$\begin{array}{c}\text { PAN- } \mathrm{GF}^{\mathrm{b}} \text { (thick } \\
2.5 \mathrm{~mm})\end{array}$} & The pristine & & & & & 94.0 & 80.9 & 76.2 & \multirow[b]{2}{*}{$\begin{array}{l}1993 \\
{[19]}\end{array}$} \\
\hline & $\begin{array}{c}\text { Thermal } \\
\text { treatment }(400 \\
\left.{ }^{\circ} \mathrm{C} \text {, Air }\right)\end{array}$ & & & & & 94.0 & 89.3 & 83.9 & \\
\hline PAN- $\mathrm{GF}^{\mathrm{c}}$ & $\begin{array}{l}\text { Electrochemic } \\
\text { al oxidation in } \\
1.0 \mathrm{M} \\
\mathrm{H}_{2} \mathrm{SO}_{4}\end{array}$ & $12 \mathrm{~cm} \mathrm{x} 18 \mathrm{~cm}$ & $\begin{array}{l}\text { PE-0 1 cation } \\
\text { exchange } \\
\text { membrane } \\
\text { (Hangzhou } \\
\text { Qianqiu } \\
\text { Water } \\
\text { Treatment } \\
\text { Co., China) }\end{array}$ & $\begin{array}{c}1.6 \mathrm{M} \mathrm{V}(\mathrm{III}) \text { in } 3 \mathrm{M} \\
\mathrm{H}_{2} \mathrm{SO}_{4} \text { at anode } \\
1.6 \mathrm{M} \mathrm{V}(\mathrm{IV}) \text { in } 3 \mathrm{M} \\
\mathrm{H}_{2} \mathrm{SO}_{4} \text { at cathode }\end{array}$ & 50 & 96.48 & 79.85 & 77.04 & $\begin{array}{l}2007 \\
{[53]}\end{array}$ \\
\hline \multirow[b]{2}{*}{$\mathrm{PAN}-\mathrm{CF}^{\mathrm{c}}$} & The pristine & \multirow[b]{2}{*}{$10 \mathrm{~cm}^{2}$} & \multirow[b]{2}{*}{$\begin{array}{c}\text { Nafion } 117 \\
\text { (DuPont, } \\
\text { USA) }\end{array}$} & \multirow{2}{*}{$\begin{array}{c}0.5 \mathrm{M} \\
\mathrm{VOSO}_{4} / 0.25 \mathrm{M} \\
\left(\mathrm{VO}_{2}\right)_{2} \mathrm{SO}_{4} \text { as } \\
\text { positive electrolyte, } \\
\text { and } 0.5 \mathrm{M} \\
\mathrm{VSO}_{4} / 0.5 \mathrm{M} \\
\mathrm{V}_{2}\left(\mathrm{SO}_{4}\right)_{3} \text { in } 2 \mathrm{M} \\
\mathrm{H}_{2} \mathrm{SO}_{4} \text { as negative } \\
\text { electrolyte }\end{array}$} & \multirow[b]{2}{*}{20} & 79.7 & 80.6 & 65.0 & \multirow[b]{2}{*}{$\begin{array}{l}2007 \\
{[58]}\end{array}$} \\
\hline & $\begin{array}{c}\text { Metalic } \\
\text { modification } \\
\text { (Ir) }\end{array}$ & & & & & 80.6 & 87.5 & 69.7 & \\
\hline \multirow[b]{2}{*}{$\begin{array}{c}\mathrm{CF} \\
\text { (thick } 5 \mathrm{~mm} \text { ) }\end{array}$} & The pristine & \multirow[b]{2}{*}{$\begin{array}{l}2.5 \mathrm{~cm} \mathrm{x} \\
2.5 \mathrm{~cm}\end{array}$} & \multirow{2}{*}{$\begin{array}{c}\text { Proton } \\
\text { exchange } \\
\text { membrane } \\
\text { (Nafion 212) }\end{array}$} & \multirow{2}{*}{$\begin{array}{c}1.5 \mathrm{M} \\
\mathrm{VO}^{2+}+2 \mathrm{M} \mathrm{H}_{2} \mathrm{SO}_{4} \\
\text { and } 1.5 \mathrm{~V}^{3+}+2 \mathrm{M} \\
\mathrm{H}_{2} \mathrm{SO}_{4}\end{array}$} & \multirow[b]{2}{*}{20} & 89.5 & 87.2 & & \multirow{2}{*}{$\begin{array}{l}2012 \\
{[70]}\end{array}$} \\
\hline & CNTs/CF & & & & & 91.5 & 90.5 & & \\
\hline
\end{tabular}




\begin{tabular}{|c|c|c|c|c|c|c|c|c|c|}
\hline $\begin{array}{c}\text { PAN- } \mathrm{CF}^{\mathrm{d}} \text { (thick } 4 \\
\mathrm{~mm})\end{array}$ & The pristine & $28 \mathrm{~cm}^{2}$ & $\begin{array}{l}\text { Nafion } 212 \\
\text { (DuPont) }\end{array}$ & $\begin{array}{c}1.5 \mathrm{M} \mathrm{VOSO}_{4}+2 \\
\mathrm{M} \mathrm{H}_{2} \mathrm{SO}_{4}\end{array}$ & 50 & 90.5 & 85.2 & 77.1 & $\begin{array}{l}2012 \\
{[77]}\end{array}$ \\
\hline \multirow[b]{2}{*}{$\begin{array}{l}\text { PAN- GFe, } \\
\text { (thick } 5 \mathrm{~mm} \text { ) }\end{array}$} & The pristine & \multirow[b]{2}{*}{$\begin{array}{c}5 \mathrm{~cm} \mathrm{x} \\
5 \mathrm{~cm}\end{array}$} & \multirow[b]{2}{*}{$\begin{array}{l}\text { Nafion } 117 \\
\text { ion exchange }\end{array}$} & \multirow{2}{*}{$\begin{array}{l}2 \mathrm{M} \mathrm{VO}^{2+} \text { in } 3 \mathrm{M} \\
\mathrm{H}_{2} \mathrm{SO}_{4} \text { at cathode } \\
2 \mathrm{M} \mathrm{V}^{3+} \text { in } 3 \mathrm{M} \\
\mathrm{H}_{2} \mathrm{SO}_{4} \text { at anode }\end{array}$} & \multirow[b]{2}{*}{80} & 90 & 77 & 70 & \multirow[b]{2}{*}{$\begin{array}{l}2013 \\
{[116]}\end{array}$} \\
\hline & $\begin{array}{c}\text { Electrochemic } \\
\text { al oxidation in } \\
\mathrm{H}_{2} \mathrm{SO}_{4} \\
\end{array}$ & & & & & 91.5 & 82.5 & 75 & \\
\hline \multirow[t]{2}{*}{$\begin{array}{l}\text { PAN- GFd } \\
\text { (thick } 6 \mathrm{~mm} \text { ) }\end{array}$} & The pristine & $5 \mathrm{~cm} \times 6 \mathrm{~cm}$ & $\begin{array}{c}\text { Membrane } \\
\text { (Nepem-1110, } \\
\text { Best Industry } \\
\& \text { Trade Co., } \\
\text { Ltd) }\end{array}$ & $\begin{array}{c}1.5 \mathrm{M} \mathrm{V}(\mathrm{IV}) / 3.0 \mathrm{M} \\
\mathrm{H}_{2} \mathrm{SO}_{4} \text { at cathode } \\
1.5 \mathrm{M} \mathrm{V}(\mathrm{III}) / 3.0 \mathrm{M} \\
\mathrm{H}_{2} \mathrm{SO}_{4} \text { at anode }\end{array}$ & 60 & 93.9 & 72.1 & 67.7 & \multirow[t]{2}{*}{$\begin{array}{l}2013 \\
{[117]}\end{array}$} \\
\hline & $\begin{array}{c}\text { Fenton's } \\
\text { Reagent/GF }\end{array}$ & & & & & 98.8 & 75.1 & 74.2 & \\
\hline \multirow[b]{2}{*}{ PAN- GF } & The pristine & \multirow[b]{2}{*}{$25 \mathrm{~cm}^{2}$} & \multirow[b]{2}{*}{ Nafion $117 \circledR$} & \multirow[b]{2}{*}{$\begin{array}{c}1 \mathrm{M} \mathrm{VOSO}_{4} \text { in } 3 \mathrm{M} \\
\mathrm{H}_{2} \mathrm{SO}_{4}\end{array}$} & \multirow[b]{2}{*}{20} & 85 & 55 & 47 & \multirow{2}{*}{$\begin{array}{l}2013 \\
{[118]}\end{array}$} \\
\hline & $\begin{array}{c}\mathrm{CuPt}_{3} \\
\text { nanoparticles/ } \\
\mathrm{GF} \\
\end{array}$ & & & & & 99 & 85 & 84 & \\
\hline \multirow{2}{*}{$\begin{array}{l}\text { PAN- GF } \\
\text { (thick } 5 \mathrm{~mm} \text { ) }\end{array}$} & The pristine & \multirow{2}{*}{$3 \mathrm{~cm} \mathrm{x3cm}$} & \multirow{2}{*}{$\begin{array}{c}\text { Perfluorinated } \\
\text { ion-exchange } \\
\text { (Best } \\
\text { Industrial } \\
\& \text { Trade Co., } \\
\text { Ltd., China) }\end{array}$} & \multirow{2}{*}{$\mathrm{VO}^{2+}(1.2 \mathrm{M})$} & \multirow{2}{*}{20} & 95.18 & \multirow{2}{*}{-} & 81.03 & \multirow{2}{*}{$\begin{array}{l}2015 \\
{[16]}\end{array}$} \\
\hline & N-dopping & & & & & 93.50 & & 86.47 & \\
\hline \multirow[b]{2}{*}{$\begin{array}{l}\text { PAN }-C^{f} \\
\text { (thick } 3 \mathrm{~mm} \text { ) }\end{array}$} & The pristine & \multirow[b]{2}{*}{$5.5 \mathrm{~cm} \times 6.0 \mathrm{~cm}$} & \multirow[b]{2}{*}{$\begin{array}{l}\text { Nafion } \\
\text { (Dupont, } \\
\text { N117) }\end{array}$} & \multirow[b]{2}{*}{$\begin{array}{l}2 \mathrm{M} \mathrm{VOSO} \\
2.5 \mathrm{M} \mathrm{H}_{2} \mathrm{SO}_{4}\end{array}$} & \multirow[b]{2}{*}{40} & 80.0 & 85.5 & 68 & \multirow[b]{2}{*}{$\begin{array}{c}2016 \\
{[5]}\end{array}$} \\
\hline & $\begin{array}{c}\text { Thermal } \\
\text { treatment }(500 \\
\left.{ }^{\circ} \mathrm{C}, \text { Air }\right) \\
\end{array}$ & & & & & 80.0 & 93.5 & 75 & \\
\hline \multirow[t]{2}{*}{ PAN- GF ${ }^{g}$} & $\begin{array}{c}\text { Chemical } \\
\text { treatment } \\
(\mathrm{KOH}) \\
\end{array}$ & \multirow[t]{2}{*}{$7 \mathrm{~cm} \times 7 \mathrm{~cm}$} & \multirow[t]{2}{*}{ Nafion 115} & \multirow{2}{*}{$\begin{array}{c}2 \mathrm{M} \mathrm{V}^{3.5+} \\
\left(\mathrm{VO}^{2+/} \mathrm{V}^{3+}=1: 1\right) \\
\text { with } 2 \mathrm{M} \mathrm{H}_{2} \mathrm{SO}_{4}\end{array}$} & 250 & 93 & 69 & 64 & \multirow{2}{*}{$\begin{array}{l}2016 \\
{[52]}\end{array}$} \\
\hline & $\begin{array}{c}0.94 \text { wt. } \% \\
\text { MWCNTs/CF }\end{array}$ & & & & & 93.9 & 87.3 & 82.0 & \\
\hline \multirow{2}{*}{ Rayon- $\mathrm{GF}^{\mathrm{h}}$} & The pristine & \multirow{2}{*}{$4 \mathrm{~cm}^{2}$} & \multirow{2}{*}{ Nafion 117 ® } & \multirow{2}{*}{$\begin{array}{c}1.0 \mathrm{M} \mathrm{VOSO}_{4} \text { in } \\
3.0 \mathrm{M} \mathrm{H}_{2} \mathrm{SO}_{4}\end{array}$} & \multirow{2}{*}{25} & 91.1 & 91.5 & 83.3 & 2016 \\
\hline & Graphene/GF & & & & & 99.5 & 96.3 & 95.8 & {$[67]$} \\
\hline
\end{tabular}

a: Fibre Materials, Inc., Maine, USA;

b: Sigri Electrographit GmbH, Germany;

c: Shanghai Energy Carbon Limited Co., China; 
d: Shenhe Carbon Fiber Materials, Co. Ltd., Liaoning China;

e: Shanghai Qijie Limited Co., China;

f: Nippon Chem. GF-3F

g: Gansu Haoshi Carbon Fiber Co., Ltd.;

h: RVG-2000, Societe Carbon-Lorraine 
Table 4-1 confirms that the battery performance was improved significantly by surface modifications compared with the untreated carbon materials. In a VRFB system where the electrolyte was charged at $1.8 \mathrm{~V}$ with a cut-off current inferior to $100 \mathrm{~mA}$, using CF (PAN, Nippon Chem. GF-3F, thickness $3 \mathrm{~mm}$ ) electrode modified by Oxygen plasma treatment could improve both the energy efficiency and discharge capacity of VRFB. The columbic efficiency (CE) for plasma treated electrodes remained almost constant throughout the galvanostatic cycling (98-100\%) [3]. The energy efficiency of a VRFB was also ameliorated by $14 \%$ at a current density of $80 \mathrm{~mA} \mathrm{~cm}{ }^{-2}$, by using treated GF (COS1011,CeTech, Taiwan, thickness 6mm) with APPJs [43]. In another study by Wang et al., the energy efficiency of the as-assembled VRFB was $8.8 \%$ higher compared to that on pristine GF with excellent cycling stability by using nitrogen-doped CNTs due to the enhancement of interaction of felts and electrolyte during the battery operation [71]. Significant improvement in energy efficiencies were well observed in cell charge-discharge cycling tests after thermal or acid treatment of the GF (Fibre, Material Inc., U.S.A., thickness $3 \mathrm{~mm}$ ). The cell resistance apparently dropped after treatment, leading to a higher average coulombic efficiency at $95.6 \%$ instead of $91.6 \%$ for untreated felts at a current density of $25 \mathrm{~mA} \mathrm{~cm}^{-2}$. Furthermore, the voltage efficiency remained high at a value of $83.0 \%$ even at a current density of $60 \mathrm{~mA} \mathrm{~cm}{ }^{-2}$ and after a total of 90 cycles on modified electrodes [46]. The electrocatalyst introduction of noble metals on the surface of felts enhances the electroconductivity of electrode materials, which reduces the reaction over potential of vanadium ion redox couples. The resistance of the cell using Ir-modified CF (Shanghai carbon works) decreased by $25 \%$ compared to the cell using non-modified felt [58]. Besides that, the energy efficiency of a VRFB with flow fields (Figure 4-2) was improved in comparison with the battery without flow fields using GF (SGL GmbH, Germany, $3 \mathrm{~mm}$ thickness). The VRFB with flow fields created also a higher discharge voltage at higher flow rates; however it had a larger pressure drop. This could be pointed out that the inclusion of flow fields in a VRFB could be an effective approach for improving the system efficiency [119]. Actually, upgrading the power density of VRFB using CF electrodes is still a fascinating topic for VRFB in the future. 


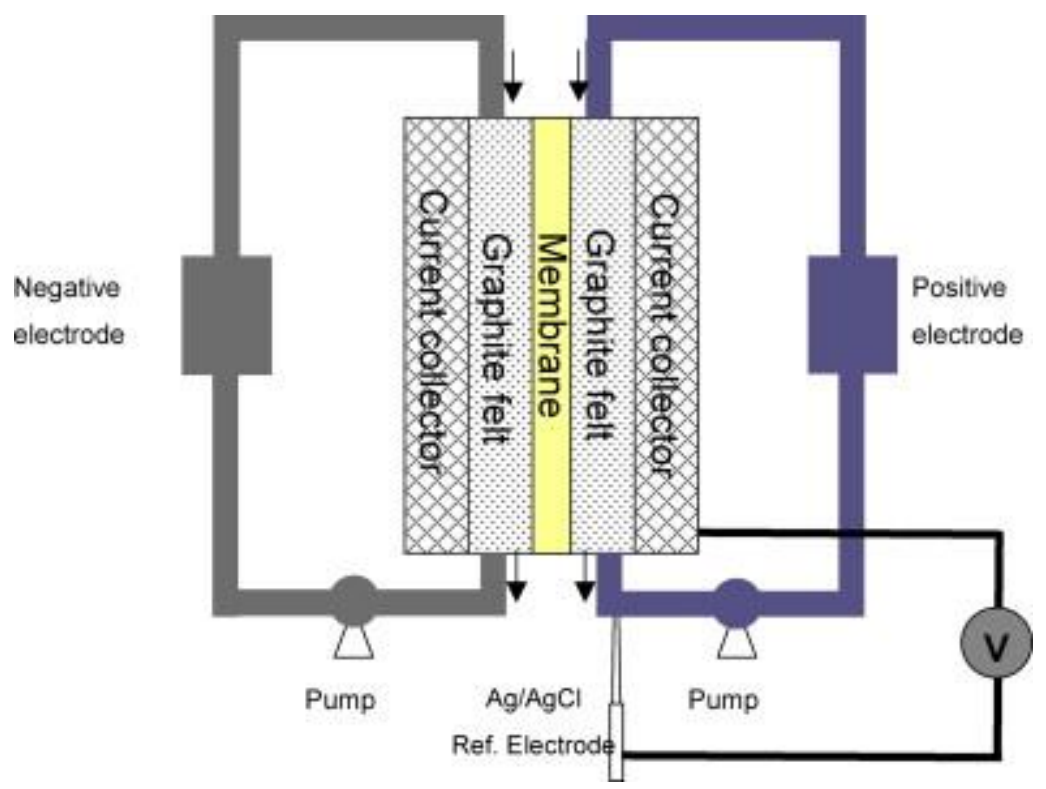

Figure 4-2. Schematic of a VRFB with flow fields using GF electrode. Reprinted from Ref. [119]. Copyright (2014), with permission from Elsevier.

\subsection{Biofuel cells}

Biofuel cells (BFCs) is a device based on the use of biocatalyst (enzymes or living cells) to convert chemical energy of organic and inorganic fuels into electrical energy [120, 121]. To develop the power density of BFCs, it is very important to improve direct electron transfer (DET) between the redox enzymes and electrodes [122]. Therefore, the choice of suitable electrodes to meet electronic properties as well as high loading of redox enzymes is essential [123, 124]. Laccase enzyme was adsorbed on three-dimensional GF (Alfa Aesar, Karlsruhe, Germany) for the oxygen reduction activity in $\mathrm{BFC}[125]$. The $\mathrm{NAD}^{+}$-dependent alcohol dehydrogenase and laccase were electrochemically deposited onto the $\mathrm{CF}$, to form the anode and cathode for singlechamber ethanol $/ \mathrm{O}_{2}$ BFC. The open-circuit voltage of this $\mathrm{BFC}$ was $860 \mathrm{mV}$. The maximum power density of the BFC was $1.56 \mathrm{~mW} \mathrm{~cm}^{-2}$. Specially, this BFC was able to work when the alcoholic beverage acted as the fuel [126]. Moreover, the CF was employed as electrodes for a sucrose $/ \mathrm{O}_{2}$ BFC. Four kinds of enzymes including invertase, mutarotase, glucose oxidase, and fructose dehydrogenase were immobilized on felts substrates via cross-linking by glutaraldehyde to fabricate bio-anodes. The bio-cathode for the oxygen reduction was prepared by coating enzyme BOD (multi-copper oxidase enzyme) with entrapment of 2,2'-azino-bis(3ethylbenzothiazoline-6-sulphonic acid) (ABTS), an efficient mediator, on CF. This BFC showed a maximum power density of $2.90 \mathrm{~mW} \mathrm{~cm}^{-2}$ recorded at $0.30 \mathrm{~V}$. The electrochemical performance of bio-anodes was also compared to electrodes on substrates using glassy carbon 
disk and CF, modified with an adequate amount of CNTs. Thanks to the good conductivity of the obtained CNTs/CF bioanode, it shows a remarkable enhancement of anodic current on CVs curve [127]. $\mathrm{A} \mathrm{H}_{2} / \mathrm{O}_{2} \mathrm{BFC}$ was constructed by using $\mathrm{CF}$ (Toray B0050 carbon felt mat,Toray Co.) as an electrode material for both the anode and the cathode. The hydrogen oxidation at anode was accelerated by methyl 2 viologen-mediated electrocatalysis with bacterial cells Desulfovibrio vulgaris (Hildenborough) as catalysts. In cathodic compartment, the oxygen reduction was accelerated by 2,2@-azinobis(3-ethylbenzothiazoline-6-sulfonate)-mediated electrocatalysis where bilirubin oxidase was used as a catalyst. A stable cell voltage around $1.17 \mathrm{~V}$ at open circuit was generated from the oxidation of dihydrogen at anode and the reduction of dioxygen at the cathode at the felt electrodes [128].

Polymer-modified felts were also employed in BFCs. Poly(methylene green) was coated on CF (Alfa Aesar) by electropolymerization applying a potential from -0.3 to $1.3 \mathrm{~V}$ for 12 sweep segments at a scan rate of $0.05 \mathrm{~V} / \mathrm{s}$ in a solution containing $0.4 \mathrm{mM}$ methylene green and $0.1 \mathrm{M}$ sodium nitrate in $10 \mathrm{mM}$ sodium tetraborate. Bio-anode was fabricated by immobilization a layer of tetrabutylammonium bromide salt-treated Nafion with dehydrogenase enzymes on the modified CF. By using this bio-anode and gas diffusion cathode in an ethanol/ $\mathrm{O}_{2} \mathrm{BFC}$, a power density of $1.16 \mathrm{~mW} \mathrm{~cm}^{-2}$ was produced. The bio-anode could operate continuously for more than 30 days, proving the good capacity of felts material for loading of enzyme to produce the energy in the BFCs system [129].

\subsection{Microbial fuel cells}

Microbial fuel cells (MFCs) have been considered as a renewable energy source where the chemical energy can be transferred directly into electrical energy though oxidization of organic substrates by electroactive bacteria. The configurations of MFCs are built up from two-chamber reactors which are separated by the proton exchange membrane (Figure 4-3). The MFCs's power is generated by fuel oxidation via bacteria at the anode and oxygen reduction at the cathode [130]. CF based electrodes are commonly used in MFCs because they are inexpensive. The electrogenic bacteria can readily attach to the felts anchoring functional groups on the surface like carboxylic acids, alcohols, and quinones because of their similarity with the natural habitat of bacteria [131]. The high conductivity of felts allows the bacteria to dispose of their waste

electrons more easily [54]. The felts electrodes used in this field can be listed as CF (Alfa Aesar) [132], GF (Xuesheng Technology Co. Ltd., China) [133], GF (Hunan Jiuhua Carbon Hi-Tech Co., Ltd., China) [101, 102], GF (RVG, Carbone Loraine, France) [134], GF (Sanye Carbon Co., 


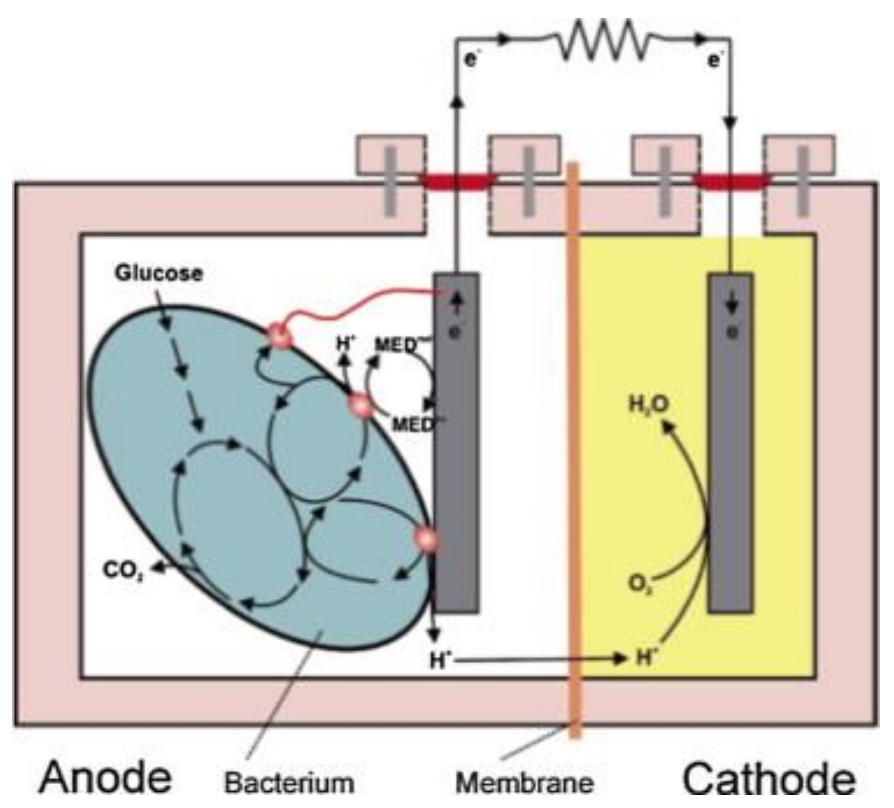

Figure 4-3. MFCs configuration. Reprinted from Ref. [137]. Copyright (2015), with permission from Elsevier.

The high electrical generation and good stability are two important keys for MFCs. In terms of these points, different kinds of modified felts were applied for both cathode and anode. For example, the power densities for both abiotic cathodes increased by $300 \%$ and biocathodes increased by $180 \%$ in MFCs using CF $(4 \mathrm{~cm} \times 3 \mathrm{~cm} \times 0.3 \mathrm{~cm})$ modified by poly (aniline-1, 8diaminonaphthalene). With the help of conductive polymer coating acting as a barrier, the cathodic biofilm became less sensitive to the dissolved oxygen as well as $\mathrm{pH}$ change in cathodic compartment, and provided better growing condition for the catalyst leading to higher power output [93]. With the aim to improve electron transfer between the microorganisms and the anodes, felts materials owning good biocompatibility have been investigated. The maximum power density of the MFCs using the PPy/GO modified GF (Beijing Sanye Co.Ltd) anode was 8 times higher than the bare GF one at $166 \mathrm{~mW} \mathrm{~m}^{-2}$. This new anode (PPy/GO-GF) proved its high stability when the MFC performance was kept nearly steadily after 120 cycles of lactate feeding [97]. CF (Liaoyang Jingu Carbon Fiber Sci-Tech Co., Ltd., China, thickness 5 mm) anode was renovated by immobilization of PPy /anthraquinone-2,6-disulphonic disodium salt (PPy/AQDS) on its surface. The MFCs operated with this modified anode showed the maximum power density of $1303 \mathrm{~mW} \mathrm{~m}^{-2}$, which was 13 times larger than that obtained from the MFCs equipped with an 
unmodified anode [138]. The coating of CNTs/PANi film on GF electrode (Beijing Sanye Co.Ltd, thickness $4 \mathrm{~mm}$ ) attained an output voltage of $342 \mathrm{mV}$. Moreover, a maximum power density was found at $257 \mathrm{~mW} \mathrm{~m}^{-2}$ which increased $343 \%$ by comparison on that of MFCs using the pristine GF [99]. Finding cathode and anode materials that exhibit enhancement properties for MFCs is a crucial problem, and is attracting a lot of attention in research and development fields.

\subsection{Capacitors - supercapacitors}

The excellent electronic performance of the modified CF makes them interesting for capacitor and supercapacitor. An electric double-layer capacitor was fabricated from growth nanocrystalline diamond (NCD) film on CF using a hot-filament CVD method. In this case, CF became an innovative material to create porous diamond electrode with large surface area that helped to increase the capacitive response. Around $8 \%$ of oxygen was found on the surface of the NCD/CF composite after treating at $1300 \mathrm{~K}$, which improved the hydrophilicity of modified electrode and made it easier for the electrolyte ion to access the micropores of electrodes material. Consequence, the internal resistance was decreased while the useable surface area was increased, which improved both the energy availability and specific capacitance. Therefore, the highest specific capacity was identified at $2.6 \mathrm{mF} \mathrm{cm}^{-2}$ for the NCD/CF-1300 K [139]. A new supercapacitor electrode was fabricated by introducing graphene/ $\mathrm{MnO}_{2}$ composites into activated carbon fiber felt (Shenzhou Carbon Fiber Co., Ltd, China., thickness $3 \mathrm{~mm}$ ). It showed a high specific capacitance up to $1516 \mathrm{mF} \mathrm{cm}^{-2}$ in neutral electrolytes. The stability of this electrode was significant as no capacitance decay after 5000 charge - discharge cycles [140]. The GF modified by $\mathrm{PPy} / \mathrm{MnO}_{2}$ composites could be also used as a free-standing electrode for supercapacitors. This electrode presented a high specific capacitance of $821.3 \mathrm{~F} \mathrm{~g}^{-1}$ at the current density of $0.5 \mathrm{~A} \mathrm{~g}^{-1}$. In fact, a unique three-dimensional network structure was constructed on GF by coating of the $\mathrm{PPy} / \mathrm{MnO}_{2}$ composites. Consequence, this modification facilitated the easy access of electrolyte to the composites and leading to enhancement of the capacitive performance [141]. Another flexible supercapacitor electrode was produced through the synthesis of tubular $\mathrm{MnOOH}$ on GF. A high energy density at $1125 \mathrm{Wh} \mathrm{kg}^{-1}$ and a power density of $5.05 \mathrm{~kW} \mathrm{~kg}^{-1}$ were monitored by applying the $\mathrm{MnOOH} / \mathrm{GF}$ supercapacitor electrode, revealing its outstanding energy-storage behavior [142]. 


\subsection{Electrochemical Solar cells}

Solar energy plays a vital type of renewable energy because of the power conversion efficiency of devices $[143,144]$. Some photosynthetic microorganisms like cyanobacteria have been used to convert directly solar energy into electric energy in an electrochemical cell [145147]. In a photosynthetic bio-electrochemical cell (Figure 4-4), at the anode, cyanobacteria, Synechococcus sp. PCC7942, were used as a photosystem. The electrons were produced from photo-oxidation of water under support of the cyanobacteria catalyst. After that, the electron was transferred to a CF (CF, Toray Co., Tokyo, Japan, thickness $1 \mathrm{~mm}$ ) anode through the mediator, 2,6-dimethyl-1,4-benzoquinone (DMBQ) or diaminodurene (DAD). Water was regenerated from dioxygen reduction through $\mathrm{ABTS}^{2-}$ (2,2'-azinobis(3-ethylbenzothiazolin-6-sulfonate)) as a mediator at the $\mathrm{CF}$ cathode and bilirubin oxidase (BOD) as a biocatalyst. About $0.3-0.4 \mathrm{~W} \mathrm{~m}^{-2}$ as the maximum electric power were generated with an apparent efficiency of the light energy conversion of $2-2.5 \%$ [148].

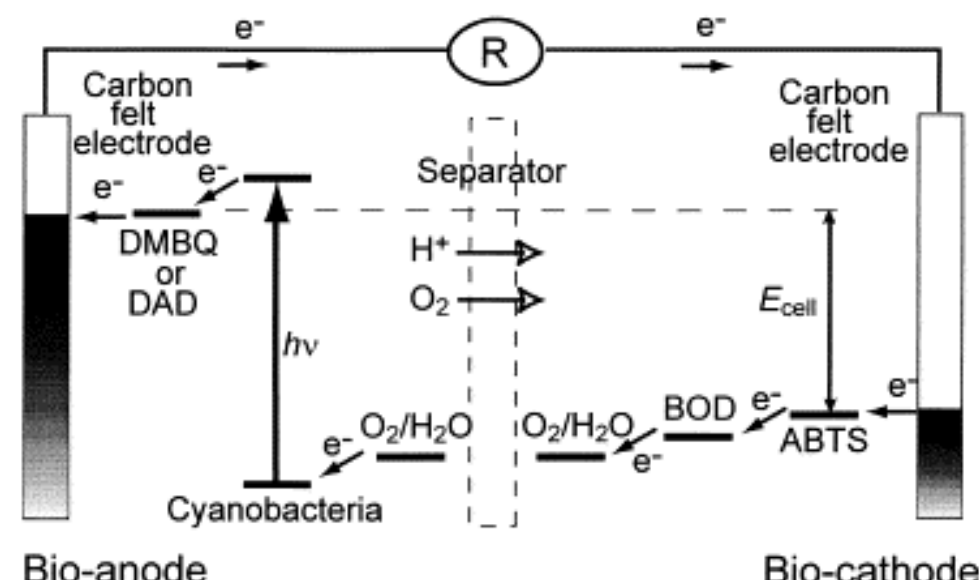

Figure 4-4. Schematic diagram of a photosynthetic bio-electrochemical cell using CF electrodes. Reprinted from Ref. [148]. Copyright (2001), with permission from Elsevier.

\subsection{Lithium ion batteries}

Owing to their high power and energy density, Li-ion batteries (LIBs) discovered in 1990s by Sony Corporation, have become the leading energy storage systems for portable applications[149]. The behavior of CF electrode modified by CNTs (CNT/CF) for energy storage was analyzed on the basis of lithium intercalation. The CNT/CF was determined as a threedimensional web of electronic conductive carbon fiber which owned excellent mechanical properties. The double-layer capacitance of $\mathrm{CNT} / \mathrm{CF}$ attained $40.3 \mu \mathrm{F} \mathrm{cm}{ }^{2}$ which was found at 
$10 \mathrm{~mA}$ of polarization current by using $1 \mathrm{~mol} \mathrm{~L}^{-1} \mathrm{LiPF}_{6}$ in mixtures of ethylene carbonate and dimethyl carbonate. Over 50 cycles of discharge/charge, the reversible specific capacity kept stably [32], proving that the modified felts electrodes will be promising material for electrochemical devices. In addition, the CF cathode after borax treatment was used in lithium-air batteries [150].

\section{Application of CF-based electrodes for wastewater treatment by electro-Fenton process}

\subsection{Introduction}

For environmental application, CF-based electrodes were used for different purposes like electrochemical reduction of heavy metals [151, 152], electrically swift ion exchange (ESIX) [96], electrosorption desalination [153], etc. In this study, we will focus on the application of felts electrodes for the wastewater treatment containing POPs by EF process. The CF-based electrodes once again proved their benefits when they were applied as cathodes during EF process to eliminate POPs in aqueous medium. First of all, an overview about EF process was understood to highlight the advantages of this technology for wastewater treatment. After that, the felts cathodes were applied to remove different kinds of POPs. In this part, we summarized the treatment efficiency by EF method using various CF-based cathodes since the year 2000. At the same time, the mineralization current efficiency (MCE), the degradation pathway, and the toxicity of treated solutions were discussed in detail. Finally, new EF systems that improve treatment efficiency and decrease the consumption costs were selected. Towards these targets, we focused both on modified cathodes to upgrade the hydrogen peroxide production and on new catalysts. Importantly, novel EF configurations in which electrons were driven by FC using modified CF will be presented as a clean and green route for the mineralization of biorefractory pollutants.

\subsection{Electro-Fenton (EF) process}

EAOPs based on Fenton's reaction chemistry are emerging technologies for water remediation. Nevertheless for Fenton reaction large amount of chemicals are requested (hydrogen peroxide), ferric hydroxide sludges formation and slow regeneration rate of the ferrous ions catalysis are limiting factors. Therefore, it was suggested that the Fenton reaction can be performed catalytically via electrochemistry [14]. Over the past decade, EAOPs have experienced important advancements, proving its high efficiency for the treatment of wastewater 
contaminated with toxic and persistent pesticides, organic synthetic dyes, pharmaceuticals and personal care products, and a great deal of industrial pollutants. Nowadays the EF process is definitely the most popular EAOP (Figure 5-1). Cathodic air feeding improves the oxygen reduction reaction (ORR) into $\mathrm{H}_{2} \mathrm{O}_{2}$ (Eq. (5-1).). $\mathrm{Fe}^{2+}, \mathrm{Fe}^{3+}$, or iron oxides are added to the effluent as catalyst reacting with hydrogen peroxide to generate hydroxyl radicals as shown in the following equations:

$$
\begin{aligned}
& \mathrm{O}_{2}+2 \mathrm{H}^{+}+2 \mathrm{e}^{-} \rightarrow \mathrm{H}_{2} \mathrm{O}_{2} \quad \mathrm{E}^{0}=0.695 \mathrm{~V} / \mathrm{SHE} \\
& \mathrm{Fe}^{2+}+\mathrm{H}_{2} \mathrm{O}_{2} \rightarrow \mathrm{Fe}^{3+}+\mathrm{OH}^{-}+\cdot \mathrm{OH} \\
& \mathrm{Fe}^{2+}+\mathrm{H}^{+}+\mathrm{H}_{2} \mathrm{O}_{2} \rightarrow \mathrm{Fe}^{3+}+\mathrm{H}_{2} \mathrm{O}+\cdot \mathrm{OH}
\end{aligned}
$$

Simultaneously, the $\mathrm{Fe}^{2+}$ ions were generated by reduction of ferric ions possibly introduced initially as catalyst to the solution to be treated [154]:

$$
\mathrm{Fe}^{3+}+\mathrm{e}^{-} \rightarrow \mathrm{Fe}^{2+} \quad \mathrm{E}^{0}=0.77 \mathrm{~V} / \mathrm{SHE}
$$

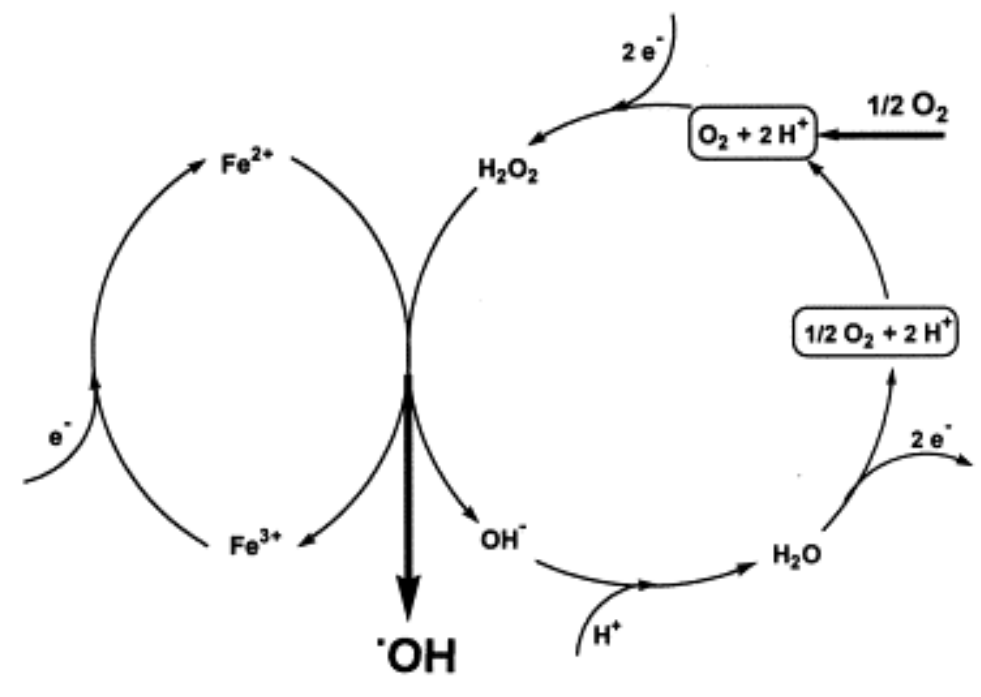

Figure 5-1. Schematic presentation of the electrocatalytic production of hydroxyl radicals by the EF process. Reprinted from Ref. [155]. Copyright (2001), with permission from Elsevier.

The EF process presents the followed advantages compared with the chemical Fenton process: (i) no need to transport, storage, and handle $\mathrm{H}_{2} \mathrm{O}_{2}$, (ii) possible control of the degradation kinetics to allow mechanistic studies, (iii) continuous cathodic regeneration of $\mathrm{Fe}^{2+}$ minimizing sludge production, and (iv) high mineralization rate at a relatively low cost after operating parameters optimization [11]. 


\subsection{CF for EF process}

$\mathrm{CF}$ is the electrode material of choice for EF process (Figure 5-2). exhibiting outstanding properties like: (i) commercial availability with good mechanical properties and high specific surface area [56, 156]; (ii) good adaptability to different shapes and surfaces from small $\left(2 \mathrm{~cm}^{2}\right)$ $[23,25]$ to large size $\left(60 \mathrm{~cm}^{2}\right)[154,157]$; and (iii) high stability to decline significantly the cost for the EF technology [158].

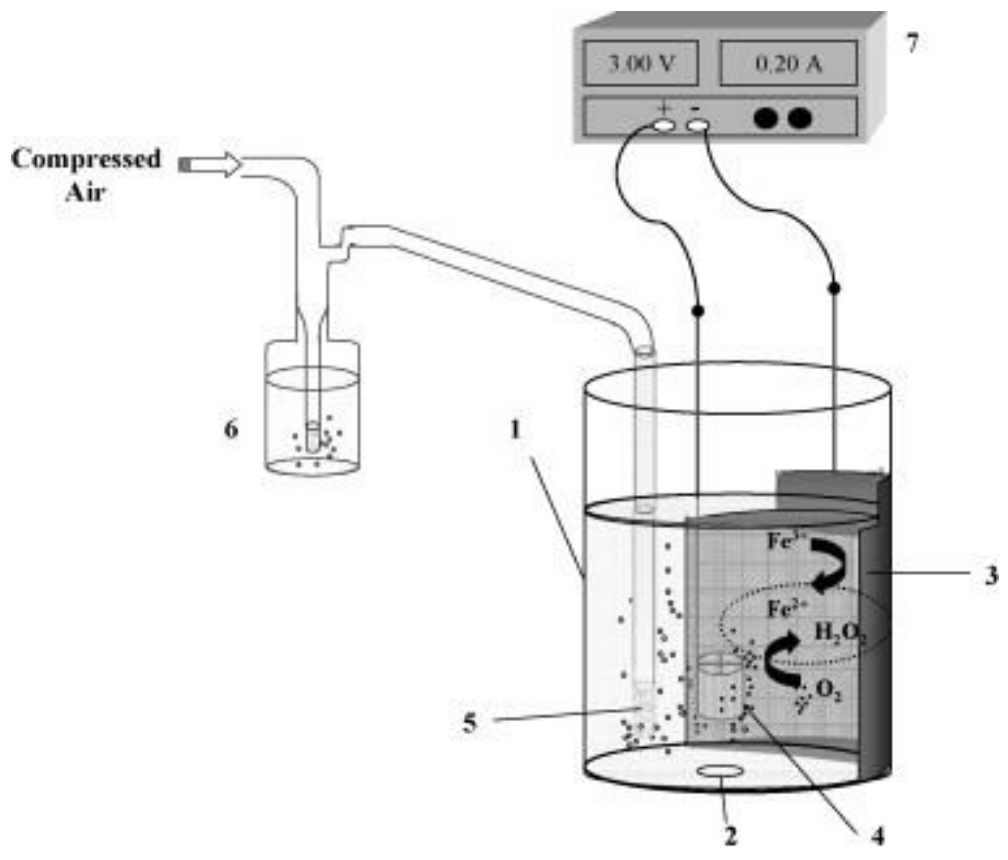

Figure 5-2. Basic laboratory experimental set-up of the EF process using CF cathode. (1) beaker containing the polluted solution, (2) magnetic stir bar, (3) CF cathode, (4) anode (Pt, Ti, etc), (5) compressed air diffuser, (6) air drying solution and (7) power supply. Reprinted from Ref. [159]. Copyright (2008), with permission from Elsevier. 
Table 5-1. Removal of POPs by EF process on graphite \& carbon felt-based cathodes in stirred tank reactor at $25^{\circ} \mathrm{C}$.

\begin{tabular}{|c|c|c|c|c|c|c|c|c|c|}
\hline $\begin{array}{l}\text { Cathode } \\
\text { material }\end{array}$ & $\begin{array}{l}\text { Geometric } \\
\text { surface } \\
\text { dimension } \\
(\mathrm{cm} \times \mathrm{cm})\end{array}$ & Anode material & Pollutants & Solution & $\begin{array}{l}\text { Applied } \\
\text { current } \\
(\mathbf{m A}) \text { or } \\
\text { potential } \\
\text { (V) }\end{array}$ & $\begin{array}{c}\text { Electrolysis } \\
\text { time }\end{array}$ & $\begin{array}{c}\text { Oxidation } \\
\text { rate constant }\end{array}$ & $\begin{array}{l}\% \text { Total } \\
\text { organic } \\
\text { carbon } \\
(\mathrm{TOC}) \\
\text { removal }\end{array}$ & Ref. \\
\hline $\begin{array}{c}\mathrm{CF}^{\mathrm{a}} \text { as } \\
\text { working } \\
\text { electrode } \\
\text { (three-electrode } \\
\text { cell) }\end{array}$ & $10 \mathrm{~cm}^{2}$ & $\begin{array}{c}1 \mathrm{~cm}^{2} \mathrm{Pt} \text { as } \\
\text { counter } \\
\text { electrode and } \\
\text { saturated } \\
\text { calomel } \\
\text { electrode (SCE) } \\
\text { as reference } \\
\text { electrode }\end{array}$ & $\begin{array}{c}2,4- \\
\text { dichlorophenoxya } \\
\text { cetic acid }\end{array}$ & $\begin{array}{c}125 \mathrm{~mL} \text { solution with } 1 \\
\mathrm{mM} \text { of pollutant, } 1 \\
\mathrm{mM} \mathrm{Fe}^{3+}, \mathrm{pH} 2 .\end{array}$ & $60 \mathrm{~mA}$ & $550 \mathrm{~min}$ & $10^{10} \mathrm{M}^{-1} \mathrm{~s}^{-1}$ & 95 & $\begin{array}{l}2000 \\
{[160]}\end{array}$ \\
\hline $\begin{array}{c}\mathrm{CF}^{\mathrm{a}} \text { as } \\
\text { working } \\
\text { electrode } \\
\text { (three-electrode } \\
\text { cell) }\end{array}$ & $10 \mathrm{~cm}^{2}$ & $\begin{array}{c}1 \mathrm{~cm}^{2} \mathrm{Pt} \text { as } \\
\text { counter } \\
\text { electrode, and } \\
\text { saturated } \\
\text { calomel } \\
\text { electrode (SCE) } \\
\text { as reference } \\
\text { electrode }\end{array}$ & Pentachlorophenol & $\begin{array}{l}125 \mathrm{~mL} \text { solution with } \\
0.03 \mathrm{mM} \text { of pollutant, } \\
\text { Mohr salt, } \mathrm{pH} 3 .\end{array}$ & $50 \mathrm{~mA}$ & $500 \mathrm{~min}$ & $\begin{array}{c}3.6 \times \underset{\mathrm{s}^{-1}}{10^{9}} \mathrm{M}^{-1} \\
\end{array}$ & 82 & $\begin{array}{l}2001 \\
{[155]}\end{array}$ \\
\hline $\mathrm{CF}$ & $\mathrm{Pt}$ & & Diuron & $\begin{array}{c}125 \mathrm{~mL} \text { solution } \\
\text { of } 40 \mathrm{mg} \mathrm{L}^{-1} \text { pollutant } \\
\text { with } 0.5 \mathrm{mM} \mathrm{Fe}^{3+} \text { in } \\
\mathrm{H}_{2} \mathrm{SO}_{4} \text { of } \mathrm{pH} 3.0\end{array}$ & $100 \mathrm{~mA}$ & $3 \mathrm{~h}$ & $\begin{array}{c}4.8 \times \underset{\mathrm{s}^{-1}}{10^{9}} \mathrm{M}^{-1} \\
\end{array}$ & 93 & $\begin{array}{l}2003 \\
{[161]}\end{array}$ \\
\hline $\mathrm{CF}^{\mathrm{a}}$ & $10 \mathrm{~cm}^{2}$ & $1 \mathrm{~cm}^{2} \mathrm{Pt}$ & Pentachlorophenol & $\begin{array}{l}125 \mathrm{~mL} \text { solution with } \\
0.21 \mathrm{mM} \text { of pollutant, } \\
0.5 \mathrm{mM} \mathrm{Fe} \mathrm{FH}^{2+}, \mathrm{pH}\end{array}$ & $200 \mathrm{~mA}$ & $7 \mathrm{~h}$ & $\begin{array}{c}3.6 \times \underset{\mathrm{s}^{-1}}{10^{9}} \mathrm{M}^{-1} \\
\end{array}$ & 95 & $\begin{array}{l}2005 \\
{[162]}\end{array}$ \\
\hline $\mathrm{CF}^{\mathrm{a}}$ & $\begin{array}{c}17 \mathrm{~cm} \times 3.5 \\
\mathrm{~cm}\end{array}$ & $4.5 \mathrm{~cm}^{2} \mathrm{Pt}$ & methyl parathion & $\begin{array}{c}150 \mathrm{~mL} \text { solution with } \\
0.20 \mathrm{mM} \text { of pollutant } \\
\text { in } 0.05 \mathrm{M} \mathrm{Na}_{2} \mathrm{SO}_{4} \text { and } \\
0.1 \mathrm{mM} \mathrm{Fe}^{2+}, \mathrm{pH} 3 .\end{array}$ & $150 \mathrm{~mA}$ & $9 \mathrm{~h}$ & $\begin{array}{c}(4.20 \pm 0.11) \mathrm{x} \\
10^{9} \mathrm{M}^{-1} \mathrm{~s}^{-1}\end{array}$ & $\sim 100$ & $\begin{array}{l}2007 \\
{[163]}\end{array}$ \\
\hline $\mathrm{CF}^{\mathrm{a}}$ & $\begin{array}{c}17 \mathrm{~cm} \times 4.1 \\
\mathrm{~cm}\end{array}$ & $\begin{array}{c}3 \mathrm{~cm}^{2} \text { Boron- } \\
\text { Doped Diamond } \\
\text { (BDD) }\end{array}$ & chlorophene & $\begin{array}{l}250 \mathrm{~mL} \text { solution with } \\
84 \mathrm{mg} \mathrm{L}^{-1} \\
\text { of pollutant in } 0.05 \mathrm{M} \\
\mathrm{Na}_{2} \mathrm{SO}_{4} \text { and } 0.2 \mathrm{mM}\end{array}$ & $300 \mathrm{~mA}$ & $6 \mathrm{~h}$ & $\begin{array}{c}(1.00 \pm 0.01) \mathrm{x} \\
10^{10} \mathrm{M}^{-1} \mathrm{~s}^{-1}\end{array}$ & $\sim 100$ & $\begin{array}{l}2007 \\
{[164]}\end{array}$ \\
\hline
\end{tabular}




\begin{tabular}{|c|c|c|c|c|c|c|c|c|c|}
\hline & & & & $\mathrm{Fe}^{3+}, \mathrm{pH} 3$ & & & & & \\
\hline $\mathrm{CF}^{\mathrm{a}}$ & $60 \mathrm{~cm}^{2}$ & $5.5 \mathrm{~cm}^{2} \mathrm{Pt}$ & Direct orange 61 & $\begin{array}{c}500 \mathrm{~mL} \text { solution with } \\
0.53 \mathrm{mM} \text { of pollutant } \\
\text { in } 0.05 \mathrm{M} \mathrm{Na}_{2} \mathrm{SO}_{4} \text { and } \\
0.1 \mathrm{mM} \mathrm{Fe}^{+2}, \mathrm{pH} 3 .\end{array}$ & $250 \mathrm{~mA}$ & $6 \mathrm{~h}$ & $\begin{array}{c}(2.06 \pm 0.14) \mathrm{x} \\
10^{10} \mathrm{M}^{-1} \mathrm{~s}^{-1}\end{array}$ & 98 & $\begin{array}{l}2007 \\
{[157]}\end{array}$ \\
\hline $\begin{array}{c}\text { CF (thick } 0.6 \\
\mathrm{~cm} \text { ) }\end{array}$ & $6 \mathrm{~cm} \times 8 \mathrm{~cm}$ & Pt grid & Phenol & $\begin{array}{c}150 \mathrm{~mL} \text { solution with } \\
1.0 \mathrm{mM} \text { of pollutant in } \\
0.05 \mathrm{M} \mathrm{Na}_{2} \mathrm{SO}_{4} \text { and } 0.1 \\
\mathrm{mM} \mathrm{Fe}^{2+}, \mathrm{pH} 3 .\end{array}$ & $300 \mathrm{~mA}$ & $7 \mathrm{~h}$ & $\begin{array}{c}(2.62 \pm 0.23) \mathrm{x} \\
10^{9} \mathrm{M}^{-1} \mathrm{~s}^{-1}\end{array}$ & 100 & $\begin{array}{l}2008 \\
{[165]}\end{array}$ \\
\hline $\mathrm{CF}^{\mathrm{a}}$ & $60 \mathrm{~cm}^{2}$ & $35 \mathrm{~cm}^{2} \mathrm{BDD}$ & $\begin{array}{l}\text { Acid orange } 7 \\
\quad(\mathrm{AO} 7)\end{array}$ & $\begin{array}{c}500 \mathrm{~mL} \text { solution with } \\
0.53 \mathrm{mM} \text { of pollutant } \\
\text { in } 0.05 \mathrm{M} \mathrm{Na}_{2} \mathrm{SO}_{4} \text { and } \\
0.1 \mathrm{mM} \mathrm{Fe}^{2+}, \mathrm{pH} 3 \text {. }\end{array}$ & $250 \mathrm{~mA}$ & $9 \mathrm{~h}$ & $\begin{array}{c}(1.10 \pm 0.04) \mathrm{x} \\
10^{10} \mathrm{M}^{-1} \mathrm{~s}^{-1}\end{array}$ & 98 & $\begin{array}{l}2008 \\
{[166]}\end{array}$ \\
\hline $\mathrm{CF}^{\mathrm{a}}$ & $60 \mathrm{~cm}^{2}$ & $\begin{array}{l}\text { Pt } 4.5 \mathrm{~cm} \text { height } \\
\text { cylindrical grid } \\
\text { (i.d. }=3.1 \mathrm{~cm} \text { ) }\end{array}$ & $\begin{array}{l}\text { Herbicide } \\
\text { chlortoluron }\end{array}$ & $\begin{array}{c}500 \mathrm{~mL} \text { solution with } \\
0.125 \mathrm{mM} \\
\text { of pollutant in } 0.05 \mathrm{M} \\
\mathrm{Na}_{2} \mathrm{SO}_{4} \text { and } 0.1 \mathrm{mM} \\
\mathrm{Fe}^{3+}, \mathrm{pH} 2.8-3 .\end{array}$ & $300 \mathrm{~mA}$ & $8 \mathrm{~h}$ & $\begin{array}{l}(4.8 \pm 0.2) \mathrm{x} \\
10^{9} \mathrm{M}^{-1} \mathrm{~s}^{-1}\end{array}$ & 98 & $\begin{array}{l}2008 \\
{[154]}\end{array}$ \\
\hline $\mathrm{CF}^{\mathrm{a}}$ & $\begin{array}{c}15 \mathrm{~cm} \times 4 \\
\mathrm{~cm}\end{array}$ & $4.5 \mathrm{~cm}^{2} \mathrm{Pt}$ & Malachite green & $\begin{array}{c}250 \mathrm{~mL} \text { solution with } \\
0.5 \mathrm{mM} \\
\text { of pollutant in } 0.05 \mathrm{M} \\
\mathrm{Na}_{2} \mathrm{SO}_{4} \text { and } 0.2 \mathrm{mM} \\
\mathrm{Fe}^{3+}, \mathrm{pH} 3 .\end{array}$ & $200 \mathrm{~mA}$ & $540 \mathrm{~min}$ & $0.244 \mathrm{~min}^{-1}$ & $\sim 100$ & $\begin{array}{l}2008 \\
{[159]}\end{array}$ \\
\hline $\mathrm{CF}^{\mathrm{a}}$ & $\begin{array}{c}15 \mathrm{~cm} \times 4 \\
\mathrm{~cm}\end{array}$ & $4.5 \mathrm{~cm}^{2} \mathrm{Pt}$ & $\begin{array}{l}\text { Triphenylmethane } \\
\text { dyes (malachite } \\
\text { green, crystal } \\
\text { violet, methyl } \\
\text { green, fast green } \\
\text { FCF) }\end{array}$ & $\begin{array}{c}250 \mathrm{~mL} \text { solution with } \\
0.5 \mathrm{mM} \\
\text { of pollutant in } 0.05 \mathrm{M} \\
\mathrm{Na}_{2} \mathrm{SO}_{4} \text { and } 0.2 \mathrm{mM} \\
\mathrm{Fe}^{3+}, \mathrm{pH} 3.0\end{array}$ & $400 \mathrm{~mA}$ & $>25 \mathrm{~h}$ & $\begin{array}{c}(1.31-2.65) \mathrm{x} \\
10^{9} \mathrm{M}^{-1} \mathrm{~s}^{-1}\end{array}$ & $\sim 100$ & $\begin{array}{l}2008 \\
{[167]}\end{array}$ \\
\hline $\mathrm{CF}$ & $\begin{array}{c}17 \mathrm{~cm} \times 3.5 \\
\mathrm{~cm}\end{array}$ & Pt gauze & $\mathrm{AO} 7$ & $\begin{array}{c}225 \mathrm{~mL} \text { solution with } \\
0.1 \mathrm{mM}^{2} \text { of pollutant in } \\
0.05 \mathrm{M} \mathrm{Na}_{2} \mathrm{SO}_{4} \text { and } 0.1 \\
\mathrm{mM} \mathrm{Fe}^{3+}, \mathrm{pH} 3 .\end{array}$ & $300 \mathrm{~mA}$ & $8 \mathrm{~h}$ & $\begin{array}{c}(1.20 \pm 0.17) \mathrm{x} \\
10^{10} \mathrm{M}^{-1} \mathrm{~s}^{-1}\end{array}$ & 92 & $\begin{array}{l}2009 \\
{[168]}\end{array}$ \\
\hline $\begin{array}{c}\mathrm{GF}^{\mathrm{a}} \\
\text { (thick } 0.5 \mathrm{~cm} \text { ) }\end{array}$ & $\begin{array}{l}15 \mathrm{~cm} \\
\times \\
4 \mathrm{~cm}\end{array}$ & $\begin{array}{l}\text { BDD } 4.5 \mathrm{~cm} \\
\text { height } \\
\text { cylindrical grid } \\
\text { (i.d. }=3.1 \mathrm{~cm} \text { ) }\end{array}$ & Alizarin Red S & $\begin{array}{l}250 \mathrm{~mL} \text { solution with } \\
200 \mathrm{mg} \mathrm{L}^{-1} \\
\text { of pollutant in } 0.05 \mathrm{M} \\
\mathrm{Na}_{2} \mathrm{SO}_{4} \text { and } 0.2 \mathrm{mM} \\
\end{array}$ & $300 \mathrm{~mA}$ & $210 \mathrm{~min}$ & $4.92 \times 10^{-4} \mathrm{~s}^{-1}$ & 95 & $\begin{array}{l}2011 \\
{[169]}\end{array}$ \\
\hline
\end{tabular}




\begin{tabular}{|c|c|c|c|c|c|c|c|c|c|}
\hline & & & & $\mathrm{Fe}^{2+}, \mathrm{pH} 3.0$ & & & & & \\
\hline Graphite sheet ${ }^{\mathrm{a}}$ & $15 \mathrm{~cm}^{2}$ & $\begin{array}{l}\text { Graphite sheet } \\
\text { (Carbon } \\
\text { Lorraine, } \\
\text { France) }\end{array}$ & Azure B & $\begin{array}{l}150 \mathrm{~mL} \text { solution with } \\
4.83 \mathrm{mg} \mathrm{L}^{-1} \\
\text { of pollutant in } 0.05 \mathrm{M} \\
\mathrm{Na}_{2} \mathrm{SO}_{4} \\
\text { and } 8.69 \mathrm{~g} \text { iron } \\
\text { alginate gelbeads } \\
(\mathrm{Fe} \mathrm{AB}), \mathrm{pH} 2.0\end{array}$ & $14.19 \mathrm{~V}$ & $30 \mathrm{~min}$ & $0.1865 \mathrm{~min}^{-1}$ & 89 & $\begin{array}{l}2012 \\
{[170]}\end{array}$ \\
\hline $\begin{array}{c}\mathrm{GF}^{\mathrm{a}} \text { (thick } 0.5 \\
\mathrm{~cm})\end{array}$ & $\begin{array}{c}10 \mathrm{~cm} \mathrm{x} 7 \\
\mathrm{~cm}\end{array}$ & $\begin{array}{l}\mathrm{Ti} / \mathrm{RuO}_{2} \text { net } 4.5 \\
\quad \mathrm{~cm} \text { height } \\
\text { cylindrical grid } \\
(\mathrm{i} . \mathrm{d}=3.1 \mathrm{~cm})\end{array}$ & p-coumaric acid & $\begin{array}{c}300 \mathrm{~mL} \text { solution with } 1 \\
\mathrm{mM} \\
\text { of pollutant in } 0.05 \mathrm{M} \\
\mathrm{Na}_{2} \mathrm{SO}_{4} \text { and } 0.3 \mathrm{mM} \\
\mathrm{Fe}^{2+}, \mathrm{pH} 3.0\end{array}$ & $300 \mathrm{~mA}$ & $360 \min$ & $0.0833 \mathrm{~min}^{-1}$ & 95 & $\begin{array}{l}2012 \\
{[171]}\end{array}$ \\
\hline $\mathrm{CF}^{\mathrm{b}}$ & $\begin{array}{c}16 \mathrm{~cm} \times 7 \\
\mathrm{~cm}\end{array}$ & $\mathrm{RuO}_{2}-\mathrm{IrO}_{2}$ & Orange II & $\begin{array}{c}200 \mathrm{~mL} \text { solution with } \\
50 \mathrm{mg} \mathrm{L}^{-1} \text { of pollutant } \\
\text { in } 0.05 \mathrm{M} \mathrm{Na}_{2} \mathrm{SO}_{4} \text { and } \\
0.2 \mathrm{mM} \mathrm{Fe}^{3+}, \mathrm{pH} 3.0\end{array}$ & $\begin{array}{c}1.78 \\
\mathrm{~mA} / \mathrm{cm} 2\end{array}$ & $90 \mathrm{~min}$ & $\begin{array}{l}0.568 \mathrm{mg} \mathrm{L}^{-1} \\
\min ^{-1} \text { for } \mathrm{H}_{2} \mathrm{O}_{2} \\
\text { production }\end{array}$ & 94.3 & $\begin{array}{l}2014 \\
{[172]}\end{array}$ \\
\hline $\begin{array}{c}\mathrm{GF}^{\mathrm{c}} \text { (thick } 0.5 \\
\mathrm{~cm})\end{array}$ & $\begin{array}{l}5 \mathrm{~cm} \times 2 \mathrm{~cm} \\
\text { (undivided } \\
\text { three- } \\
\text { electrode } \\
\text { cell) }\end{array}$ & $\begin{array}{c}\text { Pt wire as } \\
\text { counter } \\
\text { electrode and a } \\
\text { SCE as } \\
\text { reference } \\
\text { electrode } \\
\text { (undivided } \\
\text { three-electrode } \\
\text { cell }\end{array}$ & p-nitrophenol & $\begin{array}{c}130 \mathrm{~mL} \text { solution with } \\
50 \mathrm{mg} \mathrm{L}^{-1} \text { of pollutant } \\
\text { in } 0.05 \mathrm{M} \mathrm{Na}_{2} \mathrm{SO}_{4} \text { and } \\
0.2 \mathrm{mM} \mathrm{Fe}^{3+}, \mathrm{pH} 3 \text {. }\end{array}$ & $0.65 \mathrm{~V}$ & $2 \mathrm{~h}$ & - & 22.2 & $\begin{array}{c}2014 \\
{[56]}\end{array}$ \\
\hline Graphite sheet ${ }^{\mathrm{a}}$ & $11 \mathrm{~cm}^{2}$ & $\begin{array}{c}\text { BDD } \\
\text { (DiaChem, } \\
\text { Germany) }\end{array}$ & Imidacloprid & $\begin{array}{l}150 \mathrm{~mL} \text { solution with } \\
100 \mathrm{mg} \mathrm{L}^{-1} \\
\text { of pollutant in } 0.05 \mathrm{M} \\
\mathrm{Na}_{2} \mathrm{SO}_{4} \\
\text { and } 4.27 \mathrm{~g} \text { iron } \\
\text { alginate gelbeads } \\
(\mathrm{Fe} \mathrm{AB}), \mathrm{pH} 2.0\end{array}$ & $5 \mathrm{~V}$ & 4 & $0.0445 \mathrm{~min}^{-1}$ & $\begin{array}{l}90 \\
\text { (Imidacl } \\
\text { oprid } \\
\text { removal) }\end{array}$ & $\begin{array}{l}2014 \\
{[173]}\end{array}$ \\
\hline $\begin{array}{c}\mathrm{GF}^{\mathrm{a}} \text { (thick } 0.5 \\
\mathrm{~cm})\end{array}$ & $60 \mathrm{~cm}^{2}$ & $6 \mathrm{~cm}^{2} \mathrm{BDD}$ & $\begin{array}{c}\text { 4-amino-3- } \\
\text { hydroxy-2-p- } \\
\text { tolylazo- } \\
\text { naphthalene-1- } \\
\text { sulfonic } \\
\text { acid) (AHPS) }\end{array}$ & $\begin{array}{l}200 \mathrm{~mL} \text { solution with } \\
175 \mathrm{mg} \mathrm{L}^{-1} \\
\text { of pollutant in } 0.05 \mathrm{M} \\
\mathrm{Na}_{2} \mathrm{SO}_{4} \\
\text { and } 2 \mathrm{~g} \mathrm{~L}^{-1} \text { pyrite } \mathrm{pH} \\
3.0\end{array}$ & $300 \mathrm{~mA}$ & 8 & $0.33 \mathrm{~min}^{-1}$ & $\sim 100$ & $\begin{array}{l}2015 \\
{[174]}\end{array}$ \\
\hline $\mathrm{CF}^{\mathrm{a}}$ & $60 \mathrm{~cm}^{2}$ & $6 \mathrm{~cm}^{2} \mathrm{BDD}$ & Tyrosol & $200 \mathrm{~mL}$ solution with & $300 \mathrm{~mA}$ & 6 & $3.57 \times 10^{9} \mathrm{M}^{-1}$ & 90 & 2015 \\
\hline
\end{tabular}




\begin{tabular}{|c|c|c|c|c|c|c|c|c|c|}
\hline & & & & $\begin{array}{c}0.30 \mathrm{mM}\left(41 \mathrm{mg} \mathrm{L}^{-1}\right) \\
\text { of pollutant in } 0.05 \mathrm{M} \\
\mathrm{Na}_{2} \mathrm{SO}_{4} \\
\text { and } 1.0 \mathrm{~g} \mathrm{~L}^{-1} \text { pyrite } \mathrm{pH} \\
3.0 \\
.0\end{array}$ & & & $\mathrm{~s}^{-1}$ & & [175] \\
\hline $\mathrm{CF}^{\mathrm{a}}$ & $60 \mathrm{~cm}^{2}$ & $6 \mathrm{~cm}^{2} \mathrm{BDD}$ & Levofloxacin & $\begin{array}{c}200 \mathrm{~mL} \text { solution with } \\
0.23 \mathrm{mM} \text { of pollutant } \\
\text { in } 0.05 \mathrm{M} \mathrm{Na}_{2} \mathrm{SO}_{4} \\
\text { and } 1.0 \mathrm{~g} \mathrm{~L}^{-1} \mathrm{pyrite} \mathrm{pH} \\
3.0\end{array}$ & $300 \mathrm{~mA}$ & 8 & $2.5 \times 10^{-4} \mathrm{~s}^{-1}$ & 95 & $\begin{array}{l}2015 \\
{[176]}\end{array}$ \\
\hline $\begin{array}{c}\mathrm{GF}^{\mathrm{a}} \\
\text { (thick } 0.5 \mathrm{~cm} \text { ) }\end{array}$ & $\begin{array}{c}17.5 \mathrm{~cm} \times 5 \\
\mathrm{~cm}\end{array}$ & $\begin{array}{c}24 \mathrm{~cm}^{2} \text { BDD } \\
\text { (CONDIAS } \\
\text { GmbH, } \\
\text { Germany) }\end{array}$ & Sul-famethazine & $\begin{array}{c}\text { solution with } 0.25 \mathrm{mM} \\
\text { of pollutant in } 0.05 \mathrm{M} \\
\mathrm{Na}_{2} \mathrm{SO}_{4} \\
\text { and } 0.2 \mathrm{mM} \mathrm{Fe}^{2+}, \mathrm{pH} \\
3.0\end{array}$ & $1000 \mathrm{~mA}$ & 6 & $\begin{array}{c}2.9 \times 10^{9} \mathrm{M}^{-1} \\
\mathrm{~s}^{-1}\end{array}$ & 98.5 & $\begin{array}{l}2016 \\
{[177]}\end{array}$ \\
\hline $\begin{array}{c}\mathrm{CF}^{\mathrm{a}}(\text { thick } 0.5 \\
\mathrm{cm})\end{array}$ & $\begin{array}{c}14 \mathrm{~cm} \times 5 \\
\mathrm{~cm}\end{array}$ & $\begin{array}{c}\text { BDD ( } \\
5 \times 4 \mathrm{~cm}, \\
\left.\text { DIACHEM }^{\circledR}\right)\end{array}$ & Norfloxacin & $\begin{array}{c}175 \mathrm{~mL} \text { solution with } \\
0.25 \mathrm{mM} \\
\text { of pollutant in } 0.05 \mathrm{M} \\
\mathrm{Na}_{2} \mathrm{SO}_{4} \\
\text { and } 0.1 \mathrm{mM} \mathrm{Fe}^{3+}, \mathrm{pH} \\
3.0 \\
\end{array}$ & $300 \mathrm{~mA}$ & 5 & $\begin{array}{c}(1.34 \pm 0.03) \mathrm{x} \\
10^{9} \mathrm{M}^{-1} \mathrm{~s}^{-1}\end{array}$ & 97.7 & $\begin{array}{l}2016 \\
{[178]}\end{array}$ \\
\hline $\mathrm{CF}^{\mathrm{a}}$ & $17.5 \times 6 \mathrm{~cm}$ & $25 \mathrm{~cm}^{2} \mathrm{BDD}$ & Sucralose & $\begin{array}{c}220 \mathrm{~mL} \text { solution with } \\
0.2 \mathrm{mM} \text { of pollutant in } \\
0.05 \mathrm{M} \mathrm{Na}_{2} \mathrm{SO}_{4} \text { and } 0.2 \\
\mathrm{mM} \mathrm{Fe}^{2+}, \mathrm{pH} 3 .\end{array}$ & $200 \mathrm{~mA}$ & $2 \mathrm{~h}$ & - & 96.1 & $\begin{array}{l}2017 \\
{[179]}\end{array}$ \\
\hline $\mathrm{CF}$ & $70 \mathrm{~cm}^{2}$ & $\begin{array}{c}\text { BDD ( } \\
5 \times 4 \mathrm{~cm}, \\
\left.\text { DIACHEM }^{\circledR}\right)\end{array}$ & Enoxacin (ENXN) & $\begin{array}{c}175 \mathrm{~mL} \text { solution with } \\
0.25 \mathrm{mM} \\
\text { of pollutant in } 0.05 \mathrm{M} \\
\mathrm{Na}_{2} \mathrm{SO}_{4} \\
\text { and } 0.3 \mathrm{~g} \mathrm{Fe}_{2} \mathrm{O}_{3}-\mathrm{KLN} \\
\text { (kaolin), pH } 3.0\end{array}$ & $300 \mathrm{~mA}$ & 7 & $\begin{array}{c}1.24( \pm 0.04) \mathrm{x} \\
10^{9} \mathrm{M}^{-1} \mathrm{~s}^{-1}\end{array}$ & 98 & $\begin{array}{l}2017 \\
{[180]}\end{array}$ \\
\hline
\end{tabular}

a: Carbone- Lorraine;

b: Jilin Zhongxin Carbon Fiber, Co., Ltd. China

c: Shang-hai Qijie Carbon material Co.,Ltd, 
The review for the mineralization of biorefractory pollutants by EF process using felts cathodes is summarized in Table 5-1. Mineralization of POPs during EF process was a conversion process of pollutants into $\mathrm{CO}_{2}$, water, and inorganic ions (i.e. $\mathrm{NH}_{4}{ }^{+}, \mathrm{NO}_{3}{ }^{-}, \mathrm{SO}_{2}{ }^{-}$, etc) induced by the attacking of the $\bullet \mathrm{OH}$ onto organic molecules involving: (i) the dehydrogenation or abstraction of a hydrogen atom to form water, (ii) the hydroxylation or electrophilic addition to a nonsaturated bond, and (iii) electron transfer or redox reactions [11]. From statistical results, we can see that application of EF technology for elimination of POPs on CF cathodes has been preceded very early by Oturan and co-workers. One of their first papers in 2000s described the EF process in divided cell. The working electrode was a $10 \mathrm{~cm}^{2}$ piece of $\mathrm{CF}$ (Carbone-Lorraine). A saturated calomel electrode $(\mathrm{E}=0.242 \mathrm{~V}$ vs $\mathrm{NHE})$ from Radiometer was used as reference electrode and a $1 \mathrm{~cm}^{2} \mathrm{Pt}$ sheet (Radiometer) as auxiliary electrode. By this system, almost total mineralization (>95\% TOC decay) of $1 \mathrm{mM}$ of the phenoxyacetic herbicide 2,4-D after consuming 2000 coulombs was observed on EG\&G potentiostat-galvanostat [160]. Afterward, they continued developing their research using an undivided cell with two electrodes by combination of CF cathode and Pt anode for the degradation of the herbicide diuron. A very high efficiency attainted $93 \%$ TOC removal at 1000 coulombs for $125 \mathrm{~mL}$ solution containing $40 \mathrm{mg}$ $\mathrm{L}^{-1}$ diuron has been reported [161]. From that, a series of studies using EF technology for water treatment on felts cathodes have been conducted to eliminate many different kinds of POPs in aqueous medium, including:

(1) Dye pollutants: $95 \%$ TOC of the anthraquinone dye Alizarin Red S was removed in $210 \mathrm{~min}$ of electrolysis on GF (Carbone-Loraine, thickness $0.5 \mathrm{~cm}$ )/BDD [169]. A mixture containing four triphenylmethane dyes, namely malachite green, crystal violet, methyl green and fast green FCF, with initial Chemical Oxygen Demand (COD) ca. $1000 \mathrm{mg} \mathrm{L}^{-1}$ was totally depolluted with efficiency near $100 \%$ on CF (Carbone-Lorraine) [167]. Other dyes were also investigated like malachite green [159], direct orange 61 (DO 61) [157] and AO7 [158, 166, 168].

(2) For phenolic type compounds: $100 \%$ of TOC of aqueous phenol solutions was eliminated by EF process using CF cathode [165]. After 360 min of electrolysis, 95\% TOC of the p-coumaric acid (4-hydroxycinnamic acid) was removed on GF (Carbone-Loraine, thick 0.5 $\mathrm{cm}) / \mathrm{Ti}-\mathrm{RuO}_{2}$ [171]. Pentachlorophenol [155, 162], Bisphenol A [181] are also in this group.

(3) The EF treatment has also been successfully applied to mineralize the herbicides and pesticides such as chlortoluron [154], 4-chloro-2-methylphenol (PCOC) [182], chlorophenoxy acid [160, 183, 184] and methyl parathion [163]. 
(4) Chlorophene [164], triclosan and triclocarban [185] were examples for pharmaceuticals pollutants which have been degraded efficiently by EF process using felts materials.

In 2016, Özcan et al. reported a very high mineralization ratio (97.7\%) for norfloxacin $(\mathrm{NFXN})$ which has been reached after $5 \mathrm{~h}$ electrolysis on $\mathrm{CF}$ (Carbone-Lorraine, France, thickness $0.5 \mathrm{~cm})$. The value of the second order oxidation rate constant was determined as (1.34 $\pm 0.03) \times 10^{9} \mathrm{M}^{-1} \mathrm{~s}^{-1}$. BDD/CF electrodes combination leaded to high formation rate of all carboxylic acids compared to Pt (platinum-gauze)/CF combination [178]. Very recently, 2017, the EF process using $\mathrm{CF}(17.5 \times 6 \mathrm{~cm}$, Carbon-Lorraine, France) cathode was applied to treat artificial sweeteners sucralose (SUC). The mineralization current efficiency (MCE) was calculated from Eq. (5-5) [186]. MCE value for total conversion of SUC into $\mathrm{CO}_{2}$ and inorganic ions were determined at $20.17 \%$ after 60 min of electrolysis for BDD/CF cell with an applied current of $200 \mathrm{~mA}$ [179].

$\operatorname{MCE}(\%)=\frac{\mathrm{nFV}_{\mathrm{s}} \Delta(\mathrm{TOC})_{\mathrm{exp}}}{4.32 \times 10^{7} \mathrm{mIt}} \times 100$

where $\mathrm{Vs}$ is the volume $(\mathrm{L}), \mathrm{F}$ is the Faraday number, $\Delta(\mathrm{TOC})_{\exp }$ is the experimental TOC decay (mg L $\left.{ }^{-1}\right), 4.32 \times 10^{7}$ is the conversion factor $\left(3600 \mathrm{~s} \mathrm{~h}^{-1} \times 12000 \mathrm{mg}\right.$ carbon $\left.\mathrm{mol}^{-1}\right)$, I is the current that was applied (A), and $\mathrm{n}$ is the number of the electrons used for the mineralization. This number was for instance 48 for sucralose, according to the stoichiometric balance showed in the reaction (5-6):

$\mathrm{C}_{12} \mathrm{H}_{19} \mathrm{Cl}_{3} \mathrm{O}_{8}+16 \mathrm{H}_{2} \mathrm{O} \rightarrow 12 \mathrm{CO}_{2}+51 \mathrm{H}^{+}+3 \mathrm{Cl}^{-}+48 \mathrm{e}^{-}$

Initial organic pollutants are degraded by the EF process to less toxic and non-toxic compounds from the attack of hydroxyl radicals forming aromatic intermediate compounds. Afterwards the aromatic ring opening reactions create aliphatic carboxylic acids (oxalic, acetic, formic acid, etc.) and inorganic ions (i.e. ammonium, nitrate, sulfate, phosphate) as final endproducts before mineralization $[172,185]$. From that, general schemes for the mineralization of POPs have been proposed, as can be seen in Figure 5-3. 


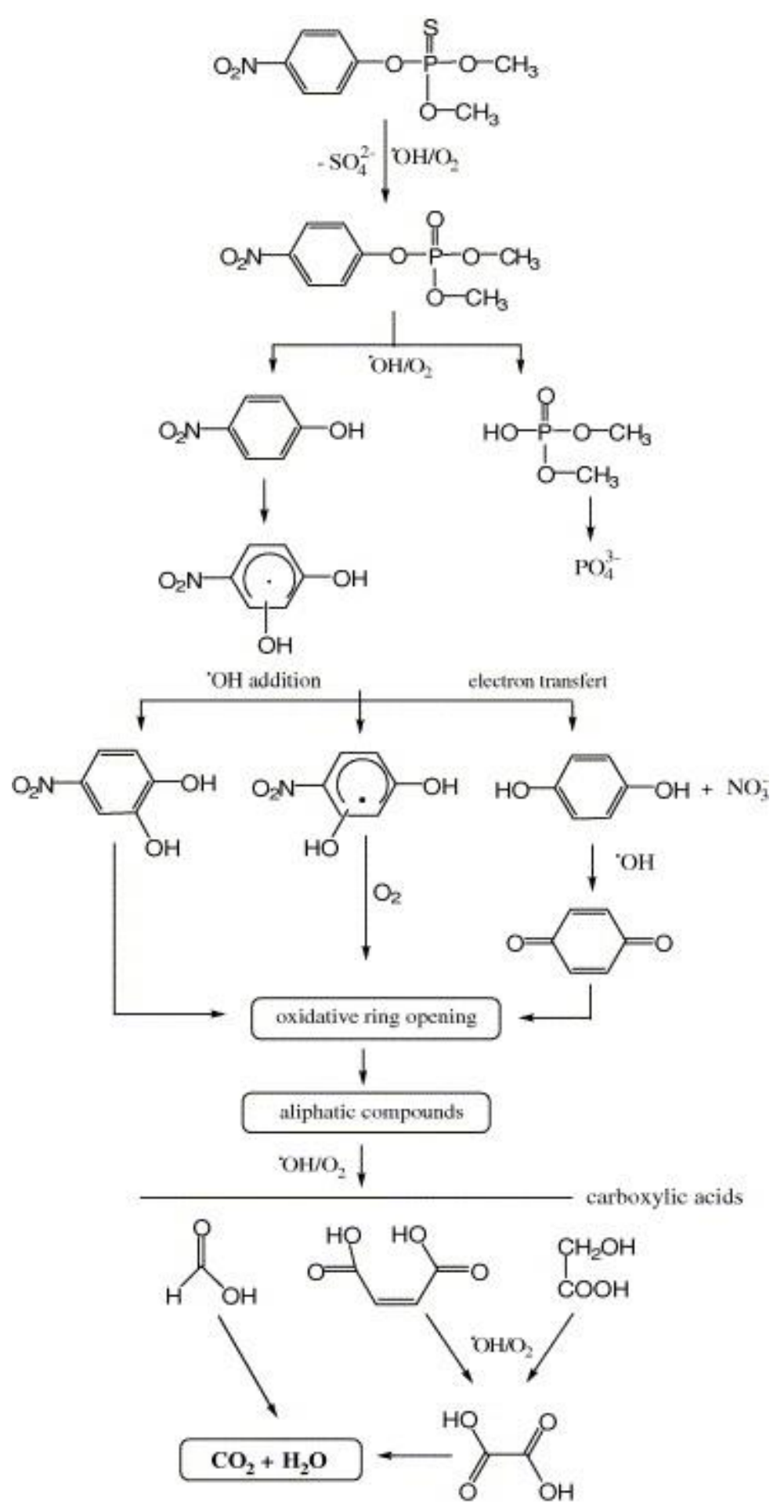

Figure 5-3. Reaction sequence for the mineralization of methyl parathion by the EF process. Reprinted from Ref. [163]. Copyright (2007), with permission from Elsevier.

$\mathrm{EF}$ process is an economically and friendly environmentally process to remove the toxicity of the recalcitrant compounds in water. Evolution of solution toxicity during the EF treatment is often followed by three periods: (i) The formation of significantly high toxic 
aromatic by-products at the beginning of the treatment as 2-naphtol and 1,2-naphtoquinone, (ii) the toxicity then decreases with disappearance of aromatics, and (iii) at the end of the treatment, this value goes down to zero which shows that the solution toxicity is in relation with aromatic compounds and that the EF mineralization leads to the detoxification of treated solution [162, 166]. In particularly, the toxicity of solutions were disappeared after $240 \mathrm{~min}$ for $220 \mathrm{~mL}$ solution with $0.2 \mathrm{mM}$ of sucralose (Figure 5-4) [179], and $60 \mathrm{~min}$ for $200 \mathrm{~mL}$ solution with $50 \mathrm{mg} \mathrm{L}^{-1}$ of Orange II [172]. The above results allow proposing EF process on CF cathode as an environmentally friendly method for the treatment of wastewater effluents containing toxic and/or POPs.

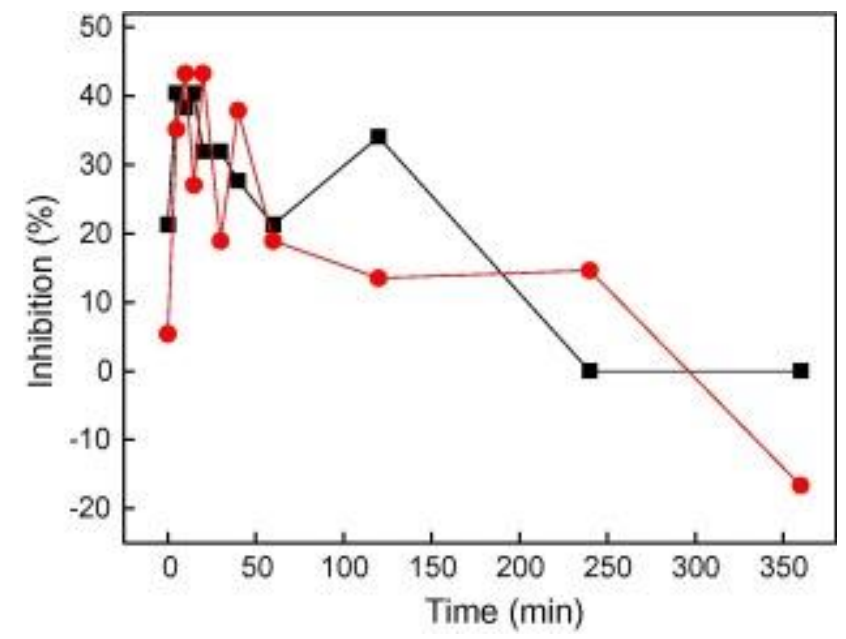

Figure 5-4. Evolution of the inhibition of marine bacteria during the EF process (Pt (- $-\mathbf{-}_{-}$) and BDD (-•) anode). ([SUC $]_{0}=0.2 \mathrm{mM},\left[\mathrm{Na}_{2} \mathrm{SO}_{4}\right]=50 \mathrm{mM},\left[\mathrm{Fe}^{2+}\right]=0.2 \mathrm{mM}, I=200 \mathrm{~mA}, \mathrm{pH}_{0}$ 3.0). Reprinted from Ref. [179]. Copyright (2017), with permission from Elsevier.

\subsection{Modified EF systems using CF cathodes}

\subsubsection{Modified felts cathodes for homogeneous EF}

The production of hydrogen peroxide and its reaction with catalyst (i.e. iron salt) in solution is a crucial factor for the effective destruction of POPs by homogeneous EF process. Aiming to improve the in situ generation of $\mathrm{H}_{2} \mathrm{O}_{2}$, various attempts have been made to upgrade the electrocatalytic characteristic of $\mathrm{CF}$ cathodes. As discussed in section 3.3, chemical modification is a simple and efficient way to ameliorate the electrochemical activity of the felt electrodes by changing their surface functional groups. After treatment in a mixture composed of ethanol and hydrazine hydrate with the volume ratio of 90/10, the concentration of $\mathrm{H}_{2} \mathrm{O}_{2}$ after 120 min was $175.8 \mathrm{mg} \mathrm{L}^{-1}$ on the modified GF (CF-B) (Shang-hai Qijie Carbon material 
Co.,Ltd.) which were nearly three times higher than $67.5 \mathrm{mg} \mathrm{L}^{-1}$ for commercial CF. The pnitrophenol mineralizationwas clearly improved with the modified cathode compared to the pristine one: TOC removal ratio moves from $22.2 \%$, to $51.4 \%$ from $\mathrm{CF}$ to CF-B.The modified electrode was stable and reusable when the mineralization ratio after 10 cycles was still above 45\% [56]. The AQDS/PPy composite film was grown on graphite electrodes by electropolymerization of the pyrrole monomer in the presence of anthraquinone-2,6-disulfonic acid. The stronger electrocatalytic activity of the AQDS/PPy/graphite cathode toward ORR compare to the pristine one is evidenced by the oxygen reduction potentials shifted to more positive values (-0.65, -0.60 , and $-0.52 \mathrm{~V} v \mathrm{SCE}$ for $\mathrm{pH} 3.0,4.0$, and 6.0, respectively) compared to the bare cathode $(-0.85,-0.82$, and $-0.77 \mathrm{~V}$ vs SCE),. Therefore, the modified cathode resulted in a large accumulation of electrogenerated $\mathrm{H}_{2} \mathrm{O}_{2}$ which increase the EF degradation of amaranth azo dye [90]. Additionally, the improvement of the $\mathrm{H}_{2} \mathrm{O}_{2}$ formation rate was found on felts cathode modified by graphene [23, 187], by heat treatment under oxygen [25], by MWCNTs [188] and by chemical treatment in $\mathrm{H}_{2} \mathrm{SO}_{4}$ solution [189].

\subsubsection{Modified felts cathodes for heterogeneous EF}

To overcome the drawbacks of basic $\mathrm{EF}$ treatments (i.e. $\mathrm{pH}$ regulation at 3, loss of soluble iron catalyst [190, 191], post-treatment requirements prior to discharge [192]) many attempts have been performed on the use of iron based heterogeneous catalyst. The self-regulation of iron ions and the possibility to work at near neutral $\mathrm{pH}$ is definitely the main advantages of heterogeneous catalyst [193]. Pyrite seems to be a good candidate to be employed as heterogeneous catalyst in EF because of reactions (5-7), (5-8) and (5-9) showing $\mathrm{Fe}^{2+}$ selfregulation and $\mathrm{pH}$ control [176]. In addition, the recovery of pyrite can be carried out easily by the filtration from the treated solution to reuse for following times. Therefore, pyrite has been used widely to remove many biorefractory pollutants in aqueous medium such as azo dye - the (4-amino-3-hydroxy-2-p-tolylazo-naphthalene-1-sulfonic acid) (AHPS) on GF (Carbone Lorraine, thickness $0.5 \mathrm{~cm}$ ) [174], antibiotic levofloxacin [176] and tyrosol [175] on CF (Carbone Lorraine), etc.

$$
\begin{aligned}
& 2 \mathrm{FeS}_{2}+2 \mathrm{H}_{2} \mathrm{O}+7 \mathrm{O}_{2} \rightarrow 2 \mathrm{Fe}^{2+}+4 \mathrm{H}^{+}+4 \mathrm{SO}_{4}{ }^{2-} \\
& 2 \mathrm{FeS}_{2}+15 \mathrm{H}_{2} \mathrm{O}_{2} \rightarrow 2 \mathrm{Fe}^{3+}+2 \mathrm{H}^{+}+14 \mathrm{H}_{2} \mathrm{O}+4 \mathrm{SO}_{4}{ }^{2-} \\
& \mathrm{FeS}_{2}+8 \mathrm{H}_{2} \mathrm{O}+14 \mathrm{Fe}^{3+} \rightarrow 15 \mathrm{Fe}^{2+}+16 \mathrm{H}^{+}+2 \mathrm{SO}_{4}{ }^{2}
\end{aligned}
$$


Besides the above treatment, iron alginate gel beads (FeAB) was used as the heterogeneous catalyst in the EF treatment in which high imidacloprid removal (90\%) was achieved. [173]. Versatility of iron alginate beads was proved with decolorisation of two typical dyes, Lissamine Green B and Azure B (87\% and 98\% respectively after $30 \mathrm{~min}$ ) maintaining FeAB particle shapes throughout the oxidation process [170]. In very recent study, Özcan et al. prepared a new iron containing $\mathrm{Fe}_{2} \mathrm{O}_{3}$ modified kaolin $\left(\mathrm{Fe}_{2} \mathrm{O}_{3}-\mathrm{KLN}\right)$ catalyst, to develop a heterogeneous EF process with three-dimensional CF cathode for the electrochemical oxidation of ENXN. The highest value of mineralization for ENXN was obtained with $0.3 \mathrm{~g}$ of catalyst at $300 \mathrm{~mA}$. with a leached concentration of iron of $0.006 \mathrm{mM}$, proving heterogeneous reactions of surface iron species was the main route [180]. A pseudo-first-order rate constant of $2.5 \times 10^{-4} \mathrm{~s}^{-1}$ $\left(\mathrm{R}^{2}=0.990\right)$ for $\mathrm{EF}$ using pyrite catalyst was nearly two times higher than electrochemical oxidation, $1.3 \times 10^{-4} \mathrm{~s}^{-1}\left(\mathrm{R}^{2}=0.992\right)$ [176] showing the performance of the heterogeneous $\mathrm{EF}$ treatment for removal pollutants was also improved comparing with that of homogeneous treatment. In addition, $\mathrm{Fe} @ \mathrm{Fe}_{2} \mathrm{O}_{3}$ [194-196], pyrrhotite [197] $\gamma$-FeOOH [198, 199] and $(\gamma$ $\mathrm{Fe}_{2} \mathrm{O}_{3} / \mathrm{F}_{3} \mathrm{O}_{4}$ oxides) nanoparticles [200] are interesting iron catalyst sources. The stable performance of these heterogeneous iron catalysts open promising perspectives for fast and economical treatment of wastewater polluted by POPs contaminants using EF treatment on CF cathodes.

\subsubsection{Hybrid EF system using CF cathodes}

To boost the degradation efficiency and reduce the treatment cost, many attempts have been made to change the EF reactor. A novel vertical-flow EF reactor (Figure 5-5 a), composing of 10 cell compartments was designed to degrade tartrazine, a model azo dye. GF cathode (Shanghai Qijie carbon material Co., Ltd) was modified with $\mathrm{PbO}_{2} / \mathrm{Ti}$ mesh anode. In comparison to the traditional parallel-flow reactor in a single chamber, the new EF system was found to be more complete and efficient. A beginning concentration of tartrazine at $100 \mathrm{mg} / \mathrm{L}$ could then reach near $100 \%$ removal. The TOC removal efficiency was $61.64 \%$ [201] thanks to a better mass transfer.

Rosales et al. designed a continuous bubble EF reactor for the degradation of wastewater contaminated with synthetic dyes attaining high decoloration rates [202]. The degradation of methyl orange (MO) by the EF process was conducted in a hemisphere-shaped quartz reactor using dual rotating GF disks (Shanghai Qijie Carbon Material Co., Ltd) cathode to supply 
oxygen. without oxygen aeration, offering a potentially cost-effective method (Figure 5-5 b) [114].

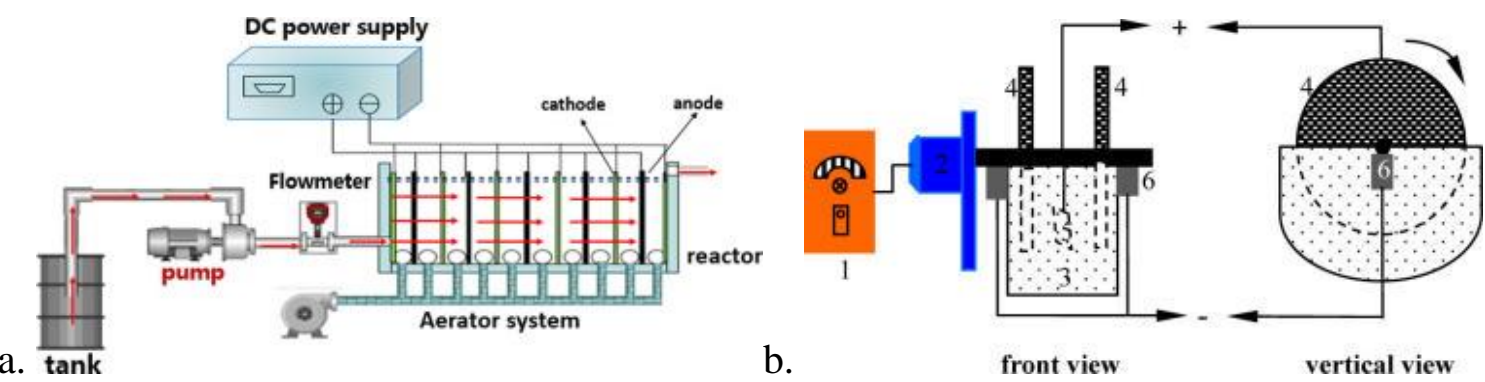

Figure 5-5. Two hybrid EF systems using CF cathode: (a) vertical-flow EF reactor; and (b) Continuous bubble EF reactor: (1) speed controller, (2) motor, (3) electrolytic cell, (4) rotating GF disk cathode, (5) Pt anode, and (6) carbon brush. Reprinted from Ref. [201] and [114]. Copyright $(2016,2014)$, with permission from Elsevier.

To further reduce the costs of electricity input for the EF treatment, bio-electro-Fenton (BEF) system has been developed to couple the EF process with MFCs which generates electricity directly from organic compounds. Fenton reactions were introduced to MFCs for bioelectrochemical degradation of paracetamol using GF at both cathode and anode without external power supply by Zhang et al. (Figure 5-6). Dual-chamber MFC reactors were employed with real domestic wastewater. In the anodic half-cell electrons were released from oxidation of biodegradable pollutants contained in the domestic waste. In the cathodic half-cell, $\mathrm{O}_{2}$ reduction promotes the hydroxyl radical -formation and the regeneration of $\mathrm{Fe}^{3+}$. To prevent diffusion of dissolved oxygen and the transfer of $\left(\mathrm{Fe}^{3+} / \mathrm{Fe}^{2+}\right)$ ions, a Nafion-117 proton exchange membrane was used [203]. 


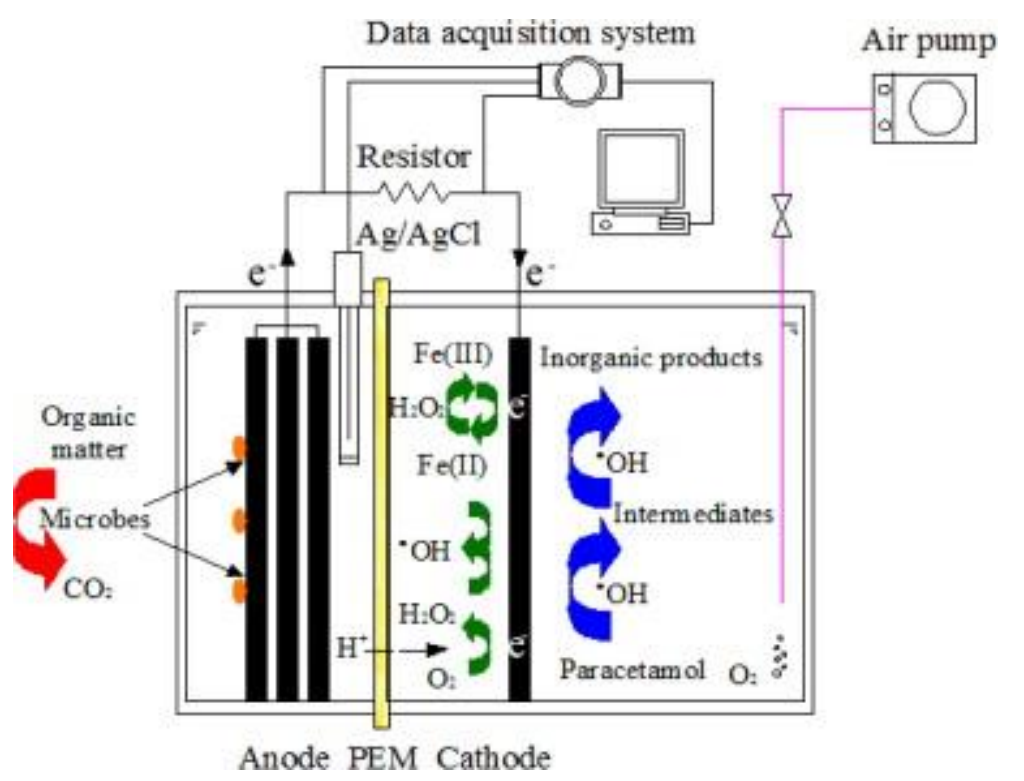

Figure 5-6. MFC-Fenton system for paracetamol degradation by EF process at cathode chamber (PEM = Proton Exchange Membrane). Reprinted from Ref. [203]. Copyright (2015), with permission from Elsevier.

The BEF system has been developed towards a clean treatment by using heterogeneous catalysis to avoid iron soluble salts adding. Birjandi et al. built up a BEF cell (Figure 5-7) with anaerobic seed sludge as biocatalyst in an anode half-cell and an aerobic cathode half-cell with a $\mathrm{Fe} @ \mathrm{Fe}_{2} \mathrm{O}_{3}$ /graphite (Entegris, Inc. FCBLK-508305-00004, USA). [195]. This BEF system was also performed by Zhuang et al. on CF $(4.5 \mathrm{~cm} \times 4.5 \mathrm{~cm}$, Liaoyang, China) [204]. The electricity generated by MFC to in situ generate $\mathrm{H}_{2} \mathrm{O}_{2}$ at a CF cathode for EF process was also investigated to remove p-nitrophenol by Zhu et al.. MFC generated a power density of $143 \mathrm{~mW} \mathrm{~m}^{-2}$ and a complete degradation of p-nitrophenol after $12 \mathrm{~h}$ [205]. The similar systems were created to remove biorefractory contaminants in wastewater sources like AO7 dye using CF (5 $\mathrm{cm}$ x $3 \mathrm{~cm}$ x $0.5 \mathrm{~cm}$, Xinka Co., Shanghai, China) [206], $17 \beta$-estradiol and 17 $\alpha$-ethynyl-estradiol estrogens using $\mathrm{Fe} @ \mathrm{Fe}_{2} \mathrm{O}_{3} / \mathrm{CF}$ (4.5 cm x 4.5 cm, Liaoyang, China) [194], azo dye (Orange II) [199] using $\mathrm{CF}$ anode and $\mathrm{CNTs} / \gamma$-FeOOH composite cathode, arsenite (As(III)) using $\gamma-\mathrm{FeOOH} / \mathrm{CF}$ (4.4 $\mathrm{cm} \times 4.4 \mathrm{~cm} \times 0.5 \mathrm{~cm}$ ) [198], Rhodamine B using $\mathrm{Fe} @ \mathrm{Fe}_{2} \mathrm{O}_{3} / \mathrm{CF}$, landfill leachate using CF (5 $\mathrm{mm}$ thickness, Beijing Sanye Carbon Co., Ltd.,China) anode and pyrrhotite/graphite $\left(5 \times 7 \mathrm{~cm}^{2}\right.$, 5mm thickness) (grade G10, Hongfeng Carbon Co., Ltd, Shanghai, China) cathode [196]. 


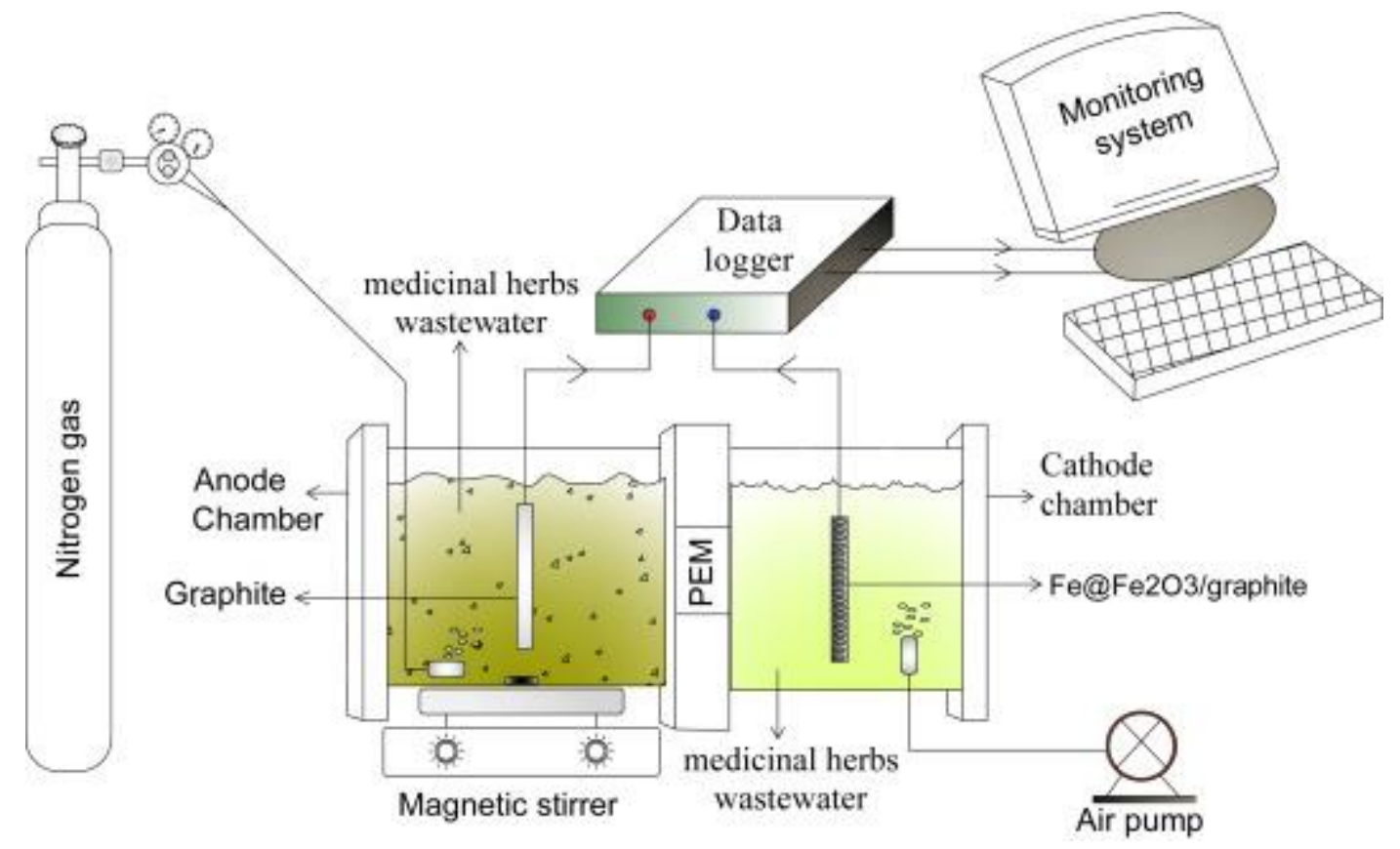

Figure 5-7. BEF system in batch mode using non-catalyzed CF for medicinal herbs wastewater treatment. Reprinted from Ref. [195]. Copyright (2016), with permission from Elsevier.

Moreover, using modified felts can improve significantly the efficiency of BEF system. The BEF with the modified electrodes, PPy/AQDS-CF $(5.0 \mathrm{~cm}$ x $5.0 \mathrm{~cm}$ x $0.6 \mathrm{~cm}$, Liaoyang Jingu Carbon Fiber Sci-Tech Co., Ltd. China), resulted in the largest rate of $\mathrm{H}_{2} \mathrm{O}_{2}$ generation in the cathode chamber by the two-electrons reduction of $\mathrm{O}_{2}$. Improving $\mathrm{H}_{2} \mathrm{O}_{2}$ concentration was beneficial for the enhancement in the amount of hydroxyl radicals allowing an increased oxidative ability of the EF process towards the decolorization and mineralization of Orange II at neutral $\mathrm{pH}$ [92]. In order to avoid the use of expensive membranes in two-chamber MFCs and to increase the generated power densities, more efficient dual reactor systems were advanced by using a single-chamber in a modified EF/MFC system (Figure 5-8). The power source from MFC was transferred directly to EF reactors constituted by CF cathode and iron plate anode as catalyst source. The TOC removal of phenol reached $75 \pm 2 \%$ in the EF reactor in one cycle after $22 \mathrm{~h}$ treatment [207]. 


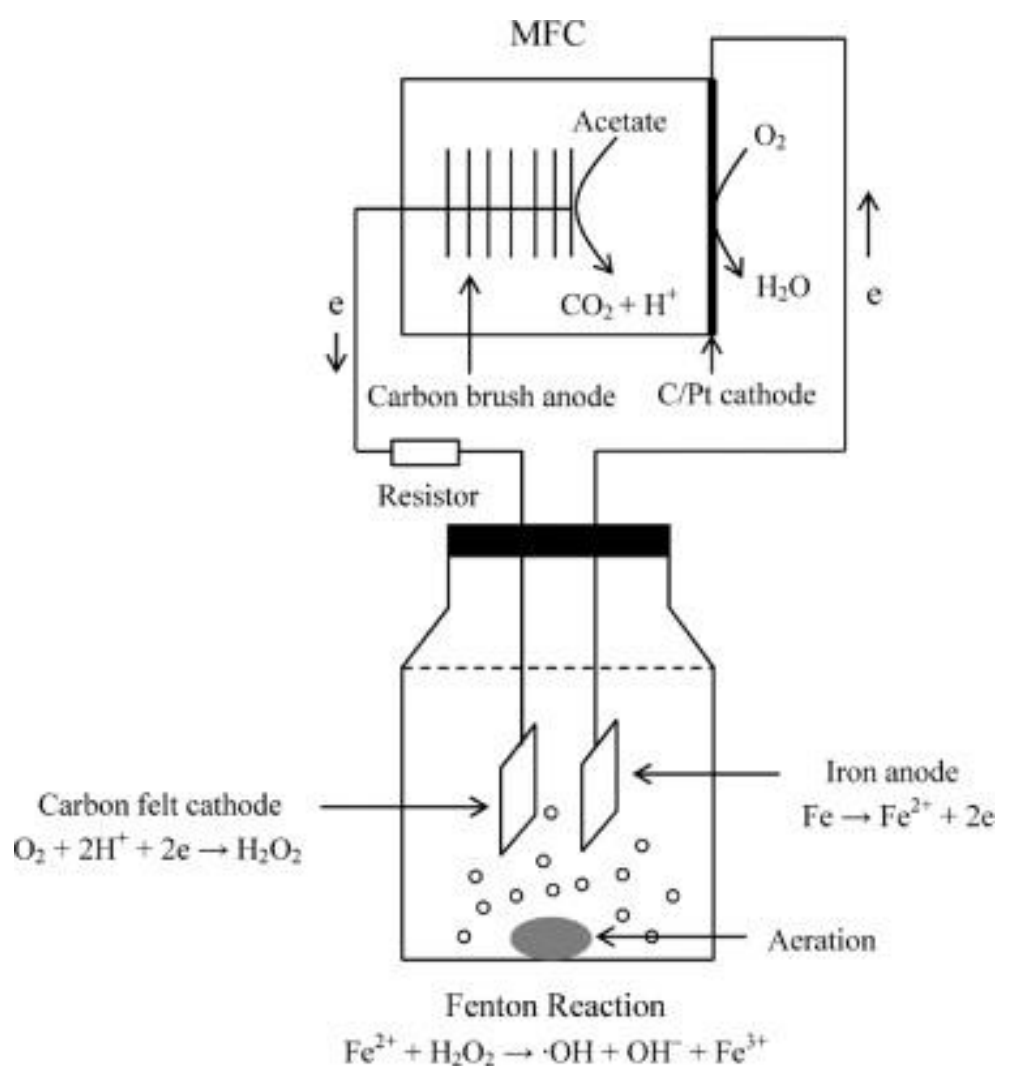

Figure 5-8. A single-chamber MFC powering the EF system. Reprinted from Ref. [207]. Copyright (2013), with permission from Elsevier.

Very recently, we discussed a novel abiotic Fuel Cell-Fenton system (Figure 5-9) for AO7 decolorization at a microporous based carbon cathode $(\mathrm{CF} /$ porous carbon $(\mathrm{pC}))$ supplied by direct clean electrical energy supplied by glucose oxidation at a $\mathrm{CF} / \mathrm{gold}$ anode (CF@Au) using nanoparticles. The cathode was prepared combining ALD of $\mathrm{ZnO}$ on commercial CF followed by solvothermal conversion to a Metal Organic Framework. The material was further calcined at high temperature under nitrogen to get a microporous carbon structure. A power output of 170 $\mathrm{mW} \mathrm{m} \mathrm{m}^{-2}$ was monitored for more than 2 months [110]. 


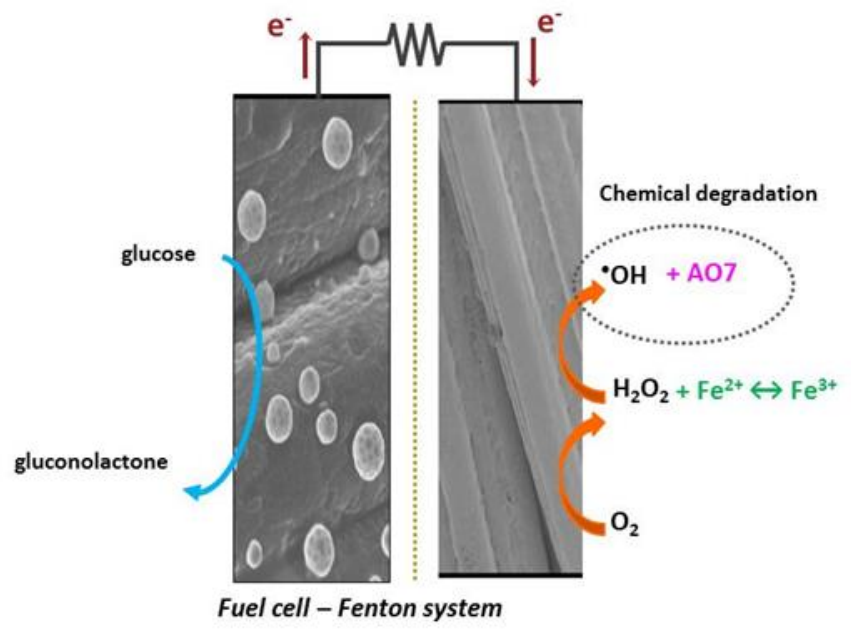

Figure 5-9. Schematic diagram of the Fuel Cell-Fenton system. Reprinted from Ref. [110]. Copyright (2016), with permission from RSC Publishing.

\subsubsection{Pilot-scale}

To assess industrial applications, the EF pilot program was set up to treat large volume of contaminated solutions. An organic micropollutant, diclofenac (DCF), from drinking water was removed by a novel EF filter pilot (Figure 5-10). The CF was used as material for both anode and cathode, with $\gamma-\mathrm{Fe}_{2} \mathrm{O}_{3} / \mathrm{F}_{3} \mathrm{O}_{4}$ nanoparticles for catalyst. The EF laboratory-scale pilot plant with a capacity of 200 L shows satisfactory stability regarding both cathode integrity and removal efficiency. The degradation and mineralization of DCF was $85 \%$ and $36 \%$, respectively [200].
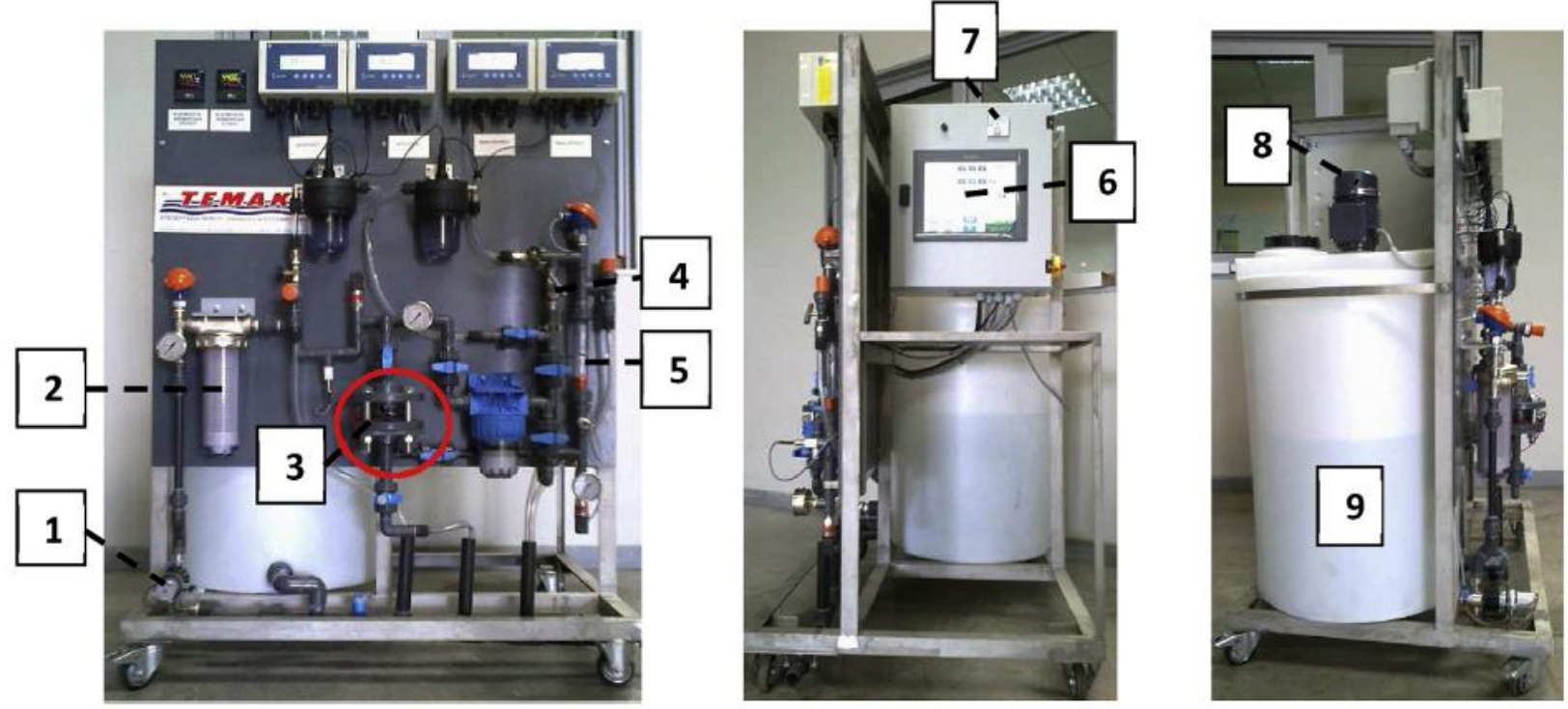

Figure 5-10. An EF pilot plant tested to treat DCF solutions; 1: feed pump, 2: cartridge filter 60 mm, 3: EF 'filter', 4: control valve, 5: flowmeter, 6: PLC (programmable logic controller), 7: 
voltage regulator, 8: powered agitator, 9: feed tank. Reprinted from Ref. [200]. Copyright (2016), with permission from Elsevier.

Besides, a solar photoelectro-Fenton $(\mathrm{SPEF})$ process in a lab-scale pilot plant $(8.0 \mathrm{~L})$ was proposed for textile dye solutions, (mainly cid yellow 42) treatment. The application of solar radiation in the process (SPEF) created higher current efficiencies and lower energy consumptions than traditional EF process [208]. A plant with a capacity of $10 \mathrm{~L}$ was also coupled to a solar compound parabolic collectors which could provide a maximum average current of 5.0 A, to degrade Yellow 4 diazo dye (Figure 5-11). At this supplied current, about 96-97\% mineralization was rapidly attained, and a reaction pathway for Direct Yellow 4 was proposed [209]. This solar pre-pilot plant was also contributed to mineralize $89 \%$ of the antibiotic chloramphenicol [210], or 94\% of sulfanilamide [211].

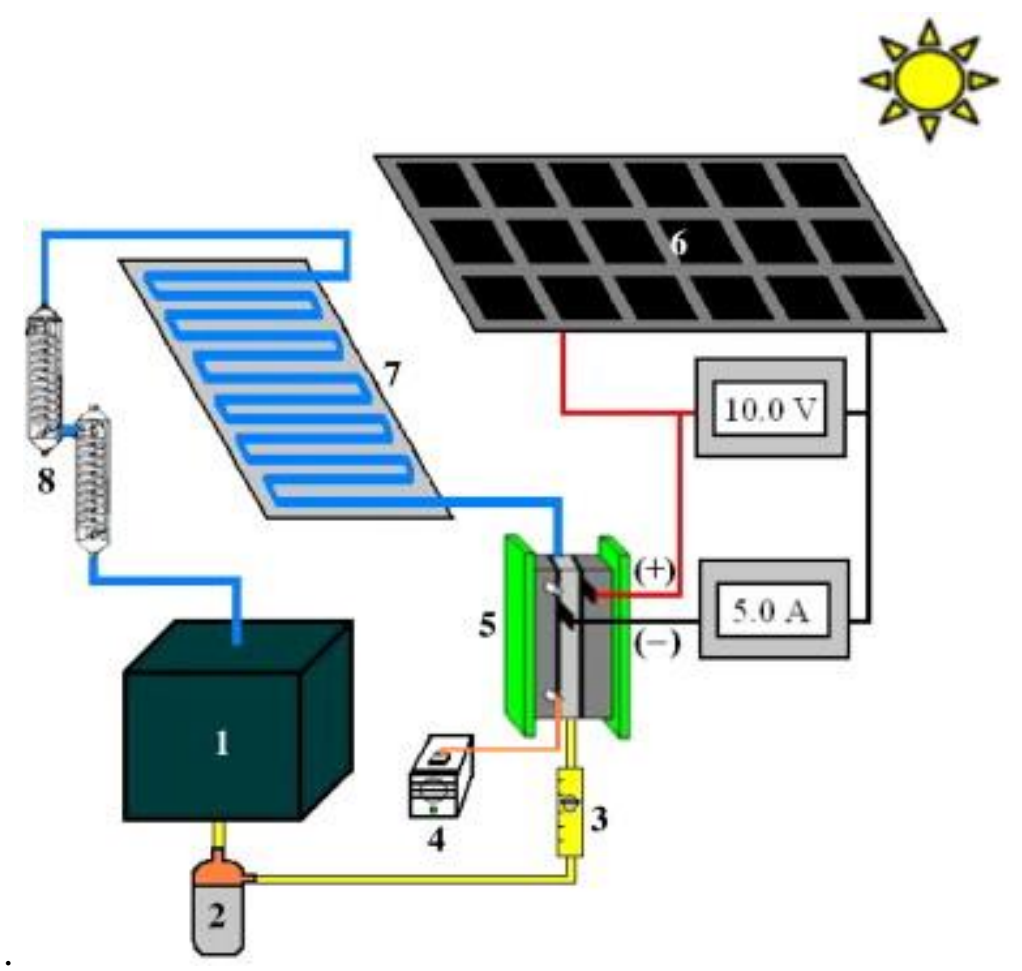

Figure 5-11. Autonomous solar pre-pilot plant used for the treatment of $10 \mathrm{~L}$ of Direct Yellow 4 (DY4) solutions: (1) Tank, (2) magnetic drive centrifugal pump, (3) flowmeter, (4) air pump, (5) electrochemical filter-press with a Pt anode and an air-diffusion cathode, (6) solar photovoltaic panel, (7) solar compound parabolic components (CPCs) and (8) heat exchangers. Reprinted from Ref. [209]. Copyright (2014), with permission from Elsevier. 


\section{Conclusion}

The CF is potential materials which have been widely applied as electrodes in energy and environmental field. Pristine felts have excellent properties with respect to electronic conductivity, chemical stability, light weight, and low cost. Although owing interesting characteristics, the studies of intrinsic properties of CF materials has been a hard task because of its hydrophobic nature and its compressibility [1]. Therefore, the choice of suitable methods added to several techniques for calculation of these structural and physical parameters of CF electrodes will still be a fascinating story in the future studies.

The CF' highly hydrophobic nature makes their application difficult in aqueous electrolyte medium. To overcome this drawback, many modification methods have been developed and used resulting in new and various benefits. Plasma, thermal, and chemical treatments change the hydrophobic surface of bare felts to hydrophilic. The enhanced wettability makes it easier for the electrolyte ions to access the active sites of the modified electrodes. Metallic nanoparticles, CNTs, carbon nanofibers, or graphene modification improved significantly the conductivity and the electroactive surface. Besides, the modification with zeolite material was also discussed. It is actually very difficult to determine the best modification method for felts electrodes. Choosing the most suitable will depend from the purpose of the fabricated electrodes. For example, for Liion battery (LIBs) applications, the CNTs modification is an elegant approach, because the LIBs required a nanostructured electrodes support for the high reversible Li intercalation capacity. For this special application, CNTs have displayed great potential owing to their novel structural, electrical and mechanical properties [2]. For microbial fuel cell applications, the biocompatibility is an important key for growing up of bacteria on felt electrode, so the polymer modification will be a wise choice. On the other hand, to create low cost electrodes, we can use simple methods with little need for expensive chemicals like chemical treatment in acid medium. In addition, the different modification methods can be combined to improve the performance of felts materials. Nowadays, this trend of combining methods attracts a lot of attention, especially methods like deposition of both gold particles and graphene [3,4], polymer with graphene [5] and CNTs with polymer [6]. Briefly, CF electrodes will become more useful with interesting properties depending on various modification methods which can be applied in a wide panel of applications.

Both pristine and modified felts were employed as electrodes in energy application like Vanadium redox flow batteries, BFCs, MFCs, capacitor, solar cell and Li-ion batteries. CF-based electrodes were popular for VRFB from the early years of 1993. The aim of these studies was to lower the cost of VRFB, so cheaper modification methods like chemical treatments were often 
chosen. Recently, some other modification methods that use graphene or CNTs have been developed and the results are impressive. We also observed similar developments in the field of microbial fuel cell. However, for capacitors, supercapacitors, electrochemical solar cells or Li-ion batteries, felts electrodes have seen little exploitation yet. For application of felts electrodes in these fields, the choice of modification is highly important, because these applications require nanostructured electrodes with considerable conductivity. Therefore, these new fields will be a fertile ground for future studies to develop new applications of CF-based electrodes.

For environmental applications, we focused in this review on the wastewater treatment containing biorefractory pollutants by EF process. The materials are cheap, non-toxic, and stable. Wastewater treatment by EF process, using the CF-based cathodes is a wise and very highly efficient choice. The use of CF as cathode for POPs removal by EF technology attained very high efficiencies where most initial contaminants were mineralized to non-toxic compound at the end of electrolysis. Many toxic biorefractory pollutants were removed completely, creating clean solutions at the end of the electrolysis. Using modified felts cathodes improved significantly hydrogen peroxide generation, an important key of EF process. To overcome the disadvantages of soluble catalyst, other iron sources were successfully applied in EF process. New configurations like vertical-flow EF reactor stacked with 10 cell compartments and continuous bubble EF process continually improve the efficiency of EF treatment. To decrease the cost of treatment and upgrade the efficiency, modified electrodes and catalysts were used. This shows a good improvement in the EF system. The felts materials were also investigated for applications in Bio-Fuel cell-Fenton in which electrons were produced from FC towards zero-energy depollution. The EF pilot programs will open doors for new applications of felts materials in industrial areas. The modification and the use of carbon based-electrodes for energy and environment applications will be a very interesting topic in the future.

\section{Perspectives}

To develop the potentials of carbon based-electrodes for future research in the environmental and energy-related field, the following trends should be considered:

(1) With respect to modifications, there have been two approaches to improve the performance of pristine felts electrodes. The first can come from searching for new materials with unique features to modify raw felts. Another path is the combination of current modification methods to take advantages of each one. For example, felts can be pre-treated by fast and simple chemical methods to create hydrophilic surface before 
applying other modification techniques. Besides that, graphene can be deposited at the same time with metallic particles or conductive polymers. The selected modification strategies should be upscaled in order to be applied on felts pieces with wide areas for pilot scale.

(2) Considering the energy application, research on the use of felts materials should be enlarged in fields of capacitor, supercapacitor, solar cell or Li-ion batteries. These applications will play an important role in digital life which is a development trend of new age.

(3) Towards the water recycling and reuse, the wastewater treatment by EF process using carbon based-cathodes should continue to grow father. The removal of new emerging pollutants can be tested by EF technology. The degradation pathways and the toxicity would be necessary investigated. In addition, the research should also pay attention to look for new modified felts with high $\mathrm{H}_{2} \mathrm{O}_{2}$ production or stable catalyst sources.

(4) The consumption cost was decreased by zero-energy EF approaches where microbial fuel cells or abiotic FC supplied clean power. These hybrid EF systems are costeffective for recalcitrant contaminants treatment, opening up new development trend for future research in the environmental and energy-related field. The idea from the airdiffusion cathodes used in the solar EF pre-pilot plants is expected to apply for CFbased electrodes in future studies.

(5) Finally, to be applicable at industrial level, research should pay attention to the low cost, high treatment efficiency, and long stability of EF pilots. There are different tendencies like using green cheap energy from FC, sunlight, and increasing the capacity of tanks to treat large volume of pollutant solutions.

\section{Acknowledgements}

We gratefully acknowledge financial support from Vietnamese government (VIEDVietnam International Education Development - Project 911). 


\section{References}

[1] Smith REG, Davies TJ, Baynes NdB, Nichols RJ. The electrochemical characterisation of graphite felts. Journal of Electroanalytical Chemistry. 2015;747:29-38.

[2] Di Blasi A, Di Blasi O, Briguglio N, Aricò AS, Sebastián D, Lázaro MJ, et al. Investigation of several graphite-based electrodes for vanadium redox flow cell. Journal of Power Sources. 2013;227:15-23.

[3] Wang Y, Hasebe Y. Carbon felt-based biocatalytic enzymatic flow-through detectors: chemical modification of tyrosinase onto amino-functionalized carbon felt using various coupling reagents. Talanta. 2009;79(4):1135-41.

[4] Han L, Tricard S, Fang J, Zhao J, Shen W. Prussian blue @ platinum nanoparticles/graphite felt nanocomposite electrodes: application as hydrogen peroxide sensor. Biosens Bioelectron. 2013;43:120-4.

[5] Kim KJ, Kim Y-J, Kim J-H, Park M-S. The effects of surface modification on carbon felt electrodes for use in vanadium redox flow batteries. Materials Chemistry and Physics. 2011;131(1-2):547-53.

[6] González Z, Sánchez A, Blanco C, Granda M, Menéndez R, Santamaría R. Enhanced performance of a Bi-modified graphite felt as the positive electrode of a vanadium redox flow battery. Electrochemistry Communications. 2011;13(12):1379-82.

[7] B. Sun, Kazacos MS. Modification of graphite electrode materials for vanadium redox flow battery application - I. Thermal treatment. Electrochim Acta. 1992;37(7):1253-60.

[8] M.H. Chakrabarti, N.P. Brandon, S.A. Hajimolana, F. Tariq, V. Yufit, M.A. Hashim, et al. Application of carbon materials in redox flow batteries. Journal of Power Sources 2014;253:150-66.

[9] Ki Jae Kim, Min-Sik Park, Young-Jun Kim, Jung Ho Kim, Shi Xue Dou, SkyllasKazacos M. A technology review of electrodes and reaction mechanisms in vanadium redox flow batteries. J Mater Chem A. 2015;3:16913-33

[10] Parasuraman A, Lim TM, Menictas C, Skyllas-Kazacos M. Review of material research and development for vanadium redox flow battery applications. Electrochimica Acta. 2013;101:27-40.

[11] Enric Brillas, Ignasi Sirés, Oturan MA. Electro-Fenton Process and Related Electrochemical Technologies Based on Fenton's Reaction Chemistry. Chem Rev 2009;109 6570-631.

[12] Nidheesh PV, Gandhimathi R. Trends in electro-Fenton process for water and wastewater treatment: An overview. Desalination. 2012;299:1-15.

[13] Rosales E, Pazos M, Sanromán MA. Advances in the Electro-Fenton Process for Remediation of Recalcitrant Organic Compounds. Chemical Engineering \& Technology. 2012;35(4):609-17.

[14] Sires I, Brillas E. Remediation of water pollution caused by pharmaceutical residues based on electrochemical separation and degradation technologies: a review. Environ Int. 2012;40:212-29.

[15] Thrower PA. Proc. Workshop Electrochemistry of Carbon, Cleveland, OH, Vol. 84-5, Proc. Vol. 84-5, The Electrochemical Society, Pennington, NJ. 1983:40.

[16] He Z, Shi L, Shen J, He Z, Liu S. Effects of nitrogen doping on the electrochemical performance of graphite felts for vanadium redox flow batteries. International Journal of Energy Research. 2015;39(5):709-16.

[17] J. Lee, N. Yun, Park J. Anisotropic properties of needle punched carbon/carbon composites. 18th Inthernational Conference on Composite Materials. 2011.

[18] Chen T, Liao J, Liu G, Zhang F, Gong Q. Effects of needle-punched felt structure on the mechanical properties of carbon/carbon composites. Carbon. 2003;41(5):993-9. 
[19] S. Zhong, C. Padeste, M. Kazacos, Kazacos MS. Comparison of the physical, chemical and electrochemical properties of rayon- and polyacrylonitrile-based graphite felt electrodes. Journal of Power Sources. 1993;45:29-41.

[20] Liu T, Li X, Nie H, Xu C, Zhang H. Investigation on the effect of catalyst on the electrochemical performance of carbon felt and graphite felt for vanadium flow batteries. Journal of Power Sources. 2015;286:73-81.

[21] HP Materials Solutions I. http://www.hpmsgraphite.com/graphite-felt.html. 2016 [cited; Available from:

[22] J. González-García, P. Bonete, E. Expósito, V. Montiel, A. Aldaz, Torregrosa-Maciá R. Characterization of a carbon felt electrode structural and physical properties. Journal of Materials Chemistry. 1999;9:419-26.

[23] Le TXH, Bechelany M, Lacour S, Oturan N, Oturan MA, Cretin M. High removal efficiency of dye pollutants by electron-Fenton process using a graphene based cathode. Carbon. 2015;94:1003-11.

[24] Dixon D, Babu DJ, Langner J, Bruns M, Pfaffmann L, Bhaskar A, et al. Effect of oxygen plasma treatment on the electrochemical performance of the rayon and polyacrylonitrile based carbon felt for the vanadium redox flow battery application. Journal of Power Sources. 2016;332:240-8.

[25] Le TXH, Charmette C, Bechelany M, Cretin M. Facile Preparation of Porous Carbon Cathode to Eliminate Paracetamol in Aqueous Medium Using Electro-Fenton System. Electrochimica Acta. 2016;188:378-84.

[26] Xiaogang L, Kelong H, Suqin L, Ning T, Liquan C. Characteristics of graphite felt electrode electrochemically oxidized for vanadium redox battery application. Transactions of Nonferrous Metals Society of China. 2007;17(1):195-9.

[27] Jan Olek, MenashiI D. Cohen, Lobo C. Determination of Surface Area of Portland Cement and Silica Fume by Mercury Intrusion Porosimetry. ACI Mater J. 1990;87:473-8.

[28] S. Langlois, Coeuret F. Flow-through and flow-by porous electrodes of nickel foam. I. Material characterization. Journal of Applied Electrochemistry. 1989;19(1):43-50.

[29] R. Carta, S. Palmas, A. M. Polcaro, Tola G. Behaviour of a carbon felt flow by electrodes Part I: Mass transfer characteristics. Journal of Applied Electrochemistry. 1991;21:793-8.

[30] C. J. Brown, D. Pletcher, F. C. Walsh, J. K. Hammond, Robinson D. Studies of threedimensional electrodes in the FMO1-LC laboratory electrolyser. Journal of Applied Electrochemistry. 1994;24(2):95-106.

[31] N. Vatistas, P. F. Marconi, Bartolozzi M. Mass-transfer study of the carbon felt electrode. Electrochim Acta. 1991;36(2):339-43.

[32] Rosolen JM, Matsubara EY, Marchesin MS, Lala SM, Montoro LA, Tronto S. Carbon nanotube/felt composite electrodes without polymer binders. Journal of Power Sources. 2006;162(1):620-8.

[33] Bard AJ, Faulkner LR. Electrochemical Methods: Fundamentals and Applications. . John Wiley and Sons: New York. 2000.

[34] Wen M, Liu H, Zhang F, Zhu Y, Liu D, Tian Y, et al. Amorphous FeNiPt nanoparticles with tunable length for electrocatalysis and electrochemical determination of thiols. Chem Commun (Camb). 2009(30):4530-2.

[35] Dogu G. Chemical Engineering, Volume 1: Fluid Flow Heat Transfer And Mass Transfer, ed. J. M. Coulson, J. F. Richardson, J. R. Backhurst and J. H. Harker. Pergamon Press, Oxford. 1978;ch. 4:125.

[36] Brownson DAC, Figueiredo-Filho LCS, Ji X, Gómez-Mingot M, Iniesta J, Fatibello-Filho $\mathrm{O}$, et al. Freestanding three-dimensional graphene foam gives rise to beneficial electrochemical signatures within non-aqueous media. Journal of Materials Chemistry A. 2013;1(19):5962. 
[37] B. Delanghe, S. Tellier, Astruc M. Mass transfer to a carbon or graphite felt electrode. Electrochimica Acta. 1990;35(9):1369-76.

[38] R. Y. Bek, Zamyatin AP. Mass-transfer cofficient and area accessible to electrolysis in flow-through graphitic-carbon-fiber electrodes. Sov Electrochem. 1978;14:1034.

[39] K. Kinoshita, Leach SC. Mass-transfer study of carbon felt, Flow-through electrode. J electrochem Sot. 1982;129:1993.

[40] D. Schmal, J. Van Erkel, Duin PJV. Mass transfer at carbon fibre electrodes. Journal of Applied Electrochemistry. 1986;16:422-30.

[41] Wang K, Chizari K, Liu Y, Janowska I, Moldovan SM, Ersen O, et al. Catalytic synthesis of a high aspect ratio carbon nanotubes bridging carbon felt composite with improved electrical conductivity and effective surface area. Applied Catalysis A: General. 2011;392(1-2):238-47.

[42] Y. Oren, Soffer A. Graphite felt as an efficient porous electrode for impurity removal and recovery of metals. Electrochimica Acta. 1983;28(11):1649-54.

[43] Chen J-Z, Liao W-Y, Hsieh W-Y, Hsu C-C, Chen Y-S. All-vanadium redox flow batteries with graphite felt electrodes treated by atmospheric pressure plasma jets. Journal of Power Sources. 2015;274:894-8.

[44] Shao Y, Wang X, Engelhard M, Wang C, Dai S, Liu J, et al. Nitrogen-doped mesoporous carbon for energy storage in vanadium redox flow batteries. Journal of Power Sources. 2010;195(13):4375-9.

[45] Ma K, Cheng JP, Liu F, Zhang X. Co-Fe layered double hydroxides nanosheets vertically grown on carbon fiber cloth for electrochemical capacitors. Journal of Alloys and Compounds. 2016;679:277-84.

[46] B. Sun, Kazacos MS. Modification of graphite electrode materials for vanadium redox flow battery application-I. Thermal treatment. Electrochim Acta. 1992;37(7):1253-60.

[47] Wu T, Huang K, Liu S, Zhuang S, Fang D, Li S, et al. Hydrothermal ammoniated treatment of PAN-graphite felt for vanadium redox flow battery. Journal of Solid State Electrochemistry. 2011;16(2):579-85.

[48] Ding C, Zhang H, Li X, Liu T, Xing F. Vanadium Flow Battery for Energy Storage: Prospects and Challenges. J Phys Chem Lett. 2013;4(8):1281-94.

[49] Hidalgo D, Tommasi T, Bocchini S, Chiolerio A, Chiodoni A, Mazzarino I, et al. Surface modification of commercial carbon felt used as anode for Microbial Fuel Cells. Energy. 2016;99:193-201.

[50] Bianting Sun, Kazacos MS. Chemical modification of graphite electrode materials for vanadium redox flow battery application-part II. Acid treatments. Electrochim Acta. 1992;37(13):2459-65.

[51] Flox C, Rubio-García J, Skoumal M, Andreu T, Morante JR. Thermo-chemical treatments based on $\mathrm{NH} 3 / \mathrm{O} 2$ for improved graphite-based fiber electrodes in vanadium redox flow batteries. Carbon. 2013;60:280-8.

[52] Zhang Z, Xi J, Zhou H, Qiu X. KOH etched graphite felt with improved wettability and activity for vanadium flow batteries. Electrochimica Acta. 2016;218:15-23.

[53] Li X-g, Huang K-1, Liu S-q, Tan N, Chen L-q. Characteristics of graphite felt electrode electrochemically oxidized for vanadium redox battery application. Transactions of Nonferrous Metals Society of China. 2007;17(1):195-9.

[54] Tang X, Guo K, Li H, Du Z, Tian J. Electrochemical treatment of graphite to enhance electron transfer from bacteria to electrodes. Bioresour Technol. 2011;102(3):3558-60.

[55] Zhou L, Hu Z, Zhang C, Bi Z, Jin T, Zhou M. Electrogeneration of hydrogen peroxide for electro-Fenton system by oxygen reduction using chemically modified graphite felt cathode. Separation and Purification Technology. 2013;111:131-6. 
[56] Zhou L, Zhou M, Hu Z, Bi Z, Serrano KG. Chemically modified graphite felt as an efficient cathode in electro-Fenton for p-nitrophenol degradation. Electrochimica Acta. 2014;140:376-83.

[57] B. Sun, Skyllas-Kazacos M. Chemical modification and electrochemical behaviour of graphite fibre in acidic vanadium solution. Electrochim Acta. 1991;36:513-7.

[58] Wang WH, Wang XD. Investigation of Ir-modified carbon felt as the positive electrode of an all-vanadium redox flow battery. Electrochimica Acta. 2007;52(24):6755-62.

[59] Lv Z, Xie D, Yue X, Feng C, Wei C. Ruthenium oxide-coated carbon felt electrode: A highly active anode for microbial fuel cell applications. Journal of Power Sources. 2012;210:2631.

[60] Solmaz R, Gündoğdu A, Döner A, Kardaş G. The Ni-deposited carbon felt as substrate for preparation of Pt-modified electrocatalysts: Application for alkaline water electrolysis. International Journal of Hydrogen Energy. 2012;37(11):8917-22.

[61] Chen S, Hu W, Hong J, Sandoe S. Electrochemical disinfection of simulated ballast water on PbO2/graphite felt electrode. Mar Pollut Bull. 2016;105(1):319-23.

[62] Zhang C, Liang P, Yang X, Jiang Y, Bian Y, Chen C, et al. Binder-free graphene and manganese oxide coated carbon felt anode for high-performance microbial fuel cell. Biosens Bioelectron. 2016;81:32-8.

[63] Wang P, Lai B, Li H, Du Z. Deposition of Fe on graphite felt by thermal decomposition of $\mathrm{Fe}(\mathrm{CO}) 5$ for effective cathodic preparation of microbial fuel cells. Bioresour Technol. 2013;134:30-5.

[64] Rao CN, Sood AK, Subrahmanyam KS, Govindaraj A. Graphene: the new twodimensional nanomaterial. Angew Chem Int Ed Engl. 2009;48(42):7752-77.

[65] Jang SK, Jeon J, Jeon SM, Song YJ, Lee S. Effects of dielectric material properties on graphene transistor performance. Solid-State Electronics. 2015;109:8-11.

[66] Chen D, Tang L, Li J. Graphene-based materials in electrochemistry. Chem Soc Rev. 2010;39(8):3157-80.

[67] González Z, Flox C, Blanco C, Granda M, Morante JR, Menéndez R, et al. Outstanding electrochemical performance of a graphene-modified graphite felt for vanadium redox flow battery application. Journal of Power Sources. 2016.

[68] Chavez-Valdez A, Shaffer MS, Boccaccini AR. Applications of graphene electrophoretic deposition. A review. J Phys Chem B. 2013;117(6):1502-15.

[69] Sehrawat P, Julien C, Islam SS. Carbon nanotubes in Li-ion batteries: A review. Materials Science and Engineering: B. 2016;213:12-40.

[70] Li W, Liu J, Yan C. The electrochemical catalytic activity of single-walled carbon nanotubes towards $\mathrm{VO} 2+/ \mathrm{VO} 2+$ and $\mathrm{V} 3+/ \mathrm{V} 2+$ redox pairs for an all vanadium redox flow battery. Electrochimica Acta. 2012;79:102-8.

[71] Wang S, Zhao X, Cochell T, Manthiram A. Nitrogen-Doped Carbon Nanotube/Graphite Felts as Advanced Electrode Materials for Vanadium Redox Flow Batteries. J Phys Chem Lett. 2012;3(16):2164-7.

[72] Mauricio Rosolen J, Patrick Poá CH, Tronto S, Marchesin MS, Silva SRP. Electron field emission of carbon nanotubes on carbon felt. Chemical Physics Letters. 2006;424(1-3):151-5.

[73] Li K-z, Li L, Li H-j, Song Q, Lu J-h, Fu Q-g. Electrophoretic deposition of carbon nanotubes onto carbon fiber felt for production of carbon/carbon composites with improved mechanical and thermal properties. Vacuum. 2014;104:105-10.

[74] Rosolen JM, Tronto S, Marchesin MS, Almeida EC, Ferreira NG, Patrick Poá CH, et al. Electron field emission from composite electrodes of carbon nanotubes-boron-doped diamond and carbon felts. Applied Physics Letters. 2006;88(8):083116. 
[75] Song Q, $\mathrm{Li} \mathrm{K}, \mathrm{Li} \mathrm{H}, \mathrm{Fu}$ Q. Increasing the Tensile Property of Unidirectional Carbon/Carbon Composites by Grafting Carbon Nanotubes onto Carbon Fibers by Electrophoretic Deposition. Journal of Materials Science \& Technology. 2013;29(8):711-4.

[76] An Q, Rider AN, Thostenson ET. Electrophoretic deposition of carbon nanotubes onto carbon-fiber fabric for production of carbon/epoxy composites with improved mechanical properties. Carbon. 2012;50(11):4130-43.

[77] Wei G, Jia C, Liu J, Yan C. Carbon felt supported carbon nanotubes catalysts composite electrode for vanadium redox flow battery application. Journal of Power Sources. 2012;220:18592.

[78] Li W, Liu J, Yan C. Multi-walled carbon nanotubes used as an electrode reaction catalyst for /VO2+ for a vanadium redox flow battery. Carbon. 2011;49(11):3463-70.

[79] Serp P. Carbon nanotubes and nanofibers in catalysis. Applied Catalysis A: General. 2003;253(2):337-58.

[80] Ledoux M-J, Pham-Huu C. Carbon nanostructures with macroscopic shaping for catalytic applications. Catalysis Today. 2005;102-103:2-14.

[81] Li P, Li T, Zhou J-H, Sui Z-J, Dai Y-C, Yuan W-K, et al. Synthesis of carbon nanofiber/graphite-felt composite as a catalyst. Microporous and Mesoporous Materials. 2006;95(1-3):1-7.

[82] Zhou JH, Zhang MG, Zhao L, Li P, Zhou XG, Yuan WK. Carbon nanofiber/graphite-felt composite supported $\mathrm{Ru}$ catalysts for hydrogenolysis of sorbitol. Catalysis Today. 2009;147:S225-S9.

[83] Vieira R, Pham-Huu C, Keller N, Ledoux MJ. New carbon nanofiber/graphite felt composite for use as a catalyst support for hydrazine catalytic decomposition. Chemical Communications. 2002(9):954-5.

[84] J. Menéndez, E. Menéndez, A. García, J. Parra, Pis J. Thermal treatment of active carbons: a comparison between microwave and electrical heating. J Microw Power Electromagn Energy. 1999;34:137-43.

[85] A.M. Schwenke, S. Hoeppener, Schubert US. Microwave synthesis of carbon nanofibers - the influence of MW irradiation power, time, and the amount of catalyst. J Mater Chem A. 2015;3:23778-87.

[86] Druzhinina T, Hoeppener S, Schubert US. On the Synthesis of Carbon Nanofibers and Nanotubes by Microwave Irradiation: Parameters, Catalysts, and Substrates. Advanced Functional Materials. 2009;19(17):2819-25.

[87] Schwenke AM, Janoschka T, Stolze C, Martin N, Hoeppener S, Schubert US. Microwave-assisted preparation of carbon nanofiber-functionalized graphite felts as electrodes for polymer-based redox-flow batteries. Journal of Power Sources. 2016;335:155-61.

[88] P. Chandrasekhar, Naishadham K. Broadband microwave absorption and shielding properties of a poly(aniline). Synthetic Metals. 1999;105:115-20.

[89] Yuehe Lin, Xiaoli Cui, Bontha J. Electrically controlled anion exchange based on polypyrrole and carbon nanotubes nanocomposite for perchlorate removal. Environ Sci Technol. 2006;40(12):4004-9.

[90] Guoquan Zhang, Fenglin Yang, Mingming Gao, Liu L. Electrocatalytic behavior of the bareand anthraquinonedisuldonatepolypyrrole composite film modified graphitecathodes in the electro-Fenton system. J Phys Chem C. 2008;112: 8957-62.

[91] Hasebe Y, Wang Y, Fukuoka K. Electropolymerized poly(Toluidine Blue)-modified carbon felt for highly sensitive amperometric determination of NADH in flow injection analysis. Journal of Environmental Sciences. 2011;23(6):1050-6. 
[92] Feng C, Li F, Liu H, Lang X, Fan S. A dual-chamber microbial fuel cell with conductive film-modified anode and cathode and its application for the neutral electro-Fenton process. Electrochimica Acta. 2010;55(6):2048-54.

[93] Li C, Ding L, Cui H, Zhang L, Xu K, Ren H. Application of conductive polymers in biocathode of microbial fuel cells and microbial community. Bioresour Technol. 2012;116:45965.

[94] Jiang X, Lou S, Chen D, Shen J, Han W, Sun X, et al. Fabrication of polyaniline/graphene oxide composite for graphite felt electrode modification and its performance in the bioelectrochemical system. Journal of Electroanalytical Chemistry. 2015;744:95-100.

[95] Mu S. Electrochemical copolymerization of aniline and o-aminophenol. Synthetic Metals. 2004;143(3):259-68.

[96] Cui H, Qian Y, An H, Sun C, Zhai J, Li Q. Electrochemical removal of fluoride from water by PAOA-modified carbon felt electrodes in a continuous flow reactor. Water Res. 2012;46(12):3943-50.

[97] Lv Z, Chen Y, Wei H, Li F, Hu Y, Wei C, et al. One-step electrosynthesis of polypyrrole/graphene oxide composites for microbial fuel cell application. Electrochimica Acta. 2013;111:366-73.

[98] Hui J, Jiang X, Xie H, Chen D, Shen J, Sun X, et al. Laccase-catalyzed electrochemical fabrication of polyaniline/graphene oxide composite onto graphite felt electrode and its application in bioelectrochemical system. Electrochimica Acta. 2016;190:16-24.

[99] Cui H-F, Du L, Guo P-B, Zhu B, Luong JHT. Controlled modification of carbon nanotubes and polyaniline on macroporous graphite felt for high-performance microbial fuel cell anode. Journal of Power Sources. 2015;283:46-53.

[100] Walcarius A. Zeolite-modifed electrodes in electroanalytical chemistry. Analytica Chimica Acta 1999;384:1-16.

[101] Wu X, Tong F, Yong X, Zhou J, Zhang L, Jia H, et al. Effect of NaX zeolite-modified graphite felts on hexavalent chromium removal in biocathode microbial fuel cells. J Hazard Mater. 2016;308:303-11.

[102] Wu X-y, Tong F, Song T-s, Gao X-y, Xie J-j, Zhou CC, et al. Effect of zeolite-coated anode on the performance of microbial fuel cells. Journal of Chemical Technology \& Biotechnology. 2015;90(1):87-92.

[103] Haghighi B, Hamidi H, Gorton L. Electrochemical behavior and application of Prussian blue nanoparticle modified graphite electrode. Sensors and Actuators B: Chemical. 2010;147(1):270-6.

[104] Ricci F, Palleschi G. Sensor and biosensor preparation, optimisation and applications of Prussian Blue modified electrodes. Biosens Bioelectron. 2005;21(3):389-407.

[105] Neff VD. Electrochemical Oxidation and Reduction of Thin Films of Prussian Blue. J Electrochem Soc. 1978;125 (6): 886-7.

[106] D.M. DeLongchamp, Hammond PT. High-contrast electrochromism and controllable dissolution of assembled Prussian blue/polymer nanocomposites. Adv Funct Mater. 2004;14:224-32.

[107] K. Itaya, I. Uchida, Neff VD. Electrochemistry of polynuclear transition metal cyanides: Prussian blue and its analogues. Acc Chem Res. 1986;19:162-8.

[108] M. Pyrasch, Tieke B. Electro- and photoresponsive films of Prussian blue prepared upon multiple sequential adsorption. Langmuir. 2001;17:7706-9.

[109] P. Zhou, D. Xue, H. Luo, Chen X. Fabrication, structure, and magnetic properties of highly ordered Prussian blue nanowire arrays. Nano Lett. 2002;2:845-7. 
[110] Thi Xuan Huong Le, Roseline Esmilaire, Martin Drobek, Mikhael Bechelany, Cyril Vallicari, Duy Linh Nguyen, et al. Design of novel Fuel Cell-Fenton system a smart approach to zero energy depollution. Journal of Materials Chemistry A. 2016;4:17686.

[111] Aaron DS, Liu Q, Tang Z, Grim GM, Papandrew AB, Turhan A, et al. Dramatic performance gains in vanadium redox flow batteries through modified cell architecture. Journal of Power Sources. 2012;206:450-3.

[112] M. Skyllas Kazacos, D. Kasherman, D.R. Hong, Kazacos M. Characteristics and performance of $1 \mathrm{~kW}$ UNSW vanadium redox battery. Journal of Power Sources 1991;35 399.

[113] M. Skyllas Kazacos, Grossmith F. Efficient Vanadium Redox Flow Cell. Journal of the Electrochemical Society 1987;134 2950.

[114] M.H. Chakrabarti, N.P. Brandon, S.A. Hajimolana, F. Tariq, V.Yufit, M.A. Hashim, et al. Application of carbon materials in redox flow batteries. Journal of Power Sources. 2014;253:15066.

[115] Vafiadis H, Skyllas-Kazacos M. Evaluation of membranes for the novel vanadium bromine redox flow cell. Journal of Membrane Science. 2006;279(1-2):394-402.

[116] Zhang W, Xi J, Li Z, Zhou H, Liu L, Wu Z, et al. Electrochemical activation of graphite felt electrode for VO2+/VO2+ redox couple application. Electrochimica Acta. 2013;89:429-35.

[117] Gao C, Wang N, Peng S, Liu S, Lei Y, Liang X, et al. Influence of Fenton's reagent treatment on electrochemical properties of graphite felt for all vanadium redox flow battery. Electrochimica Acta. 2013;88:193-202.

[118] Flox C, Skoumal M, Rubio-Garcia J, Andreu T, Morante JR. Strategies for enhancing electrochemical activity of carbon-based electrodes for all-vanadium redox flow batteries. Applied Energy. 2013;109:344-51.

[119] $\mathrm{Xu} \mathrm{Q}$, Zhao TS, Zhang C. Performance of a vanadium redox flow battery with and without flow fields. Electrochimica Acta. 2014;142:61-7.

[120] S.C. Barton, J. Gallaway, Atanassov P. Enzymatic biofuel cells for implantable and microscale devices. Chem Rev. 2004;104 4867-86.

[121] Bullen RA, Arnot TC, Lakeman JB, Walsh FC. Biofuel cells and their development. Biosens Bioelectron. 2006;21(11):2015-45.

[122] Coman V, Ludwig R, Harreither W, Haltrich D, Gorton L, Ruzgas T, et al. A Direct Electron Transfer-Based Glucose/Oxygen Biofuel Cell Operating in Human Serum. Fuel Cells. 2009:NA-NA.

[123] Gao F, Viry L, Maugey M, Poulin P, Mano N. Engineering hybrid nanotube wires for high-power biofuel cells. Nat Commun. 2010;1:2.

[124] Osman MH, Shah AA, Walsh FC. Recent progress and continuing challenges in bio-fuel cells. Part I: enzymatic cells. Biosens Bioelectron. 2011;26(7):3087-102.

[125] Rubenwolf S, Strohmeier O, Kloke A, Kerzenmacher S, Zengerle R, von Stetten F. Carbon electrodes for direct electron transfer type laccase cathodes investigated by current density-cathode potential behavior. Biosens Bioelectron. 2010;26(2):841-5.

[126] Deng L, Shang L, Wen D, Zhai J, Dong S. A membraneless biofuel cell powered by ethanol and alcoholic beverage. Biosens Bioelectron. 2010;26(1):70-3.

[127] Handa Y, Yamagiwa K, Ikeda Y, Yanagisawa Y, Watanabe S, Yabuuchi N, et al. Fabrication of carbon-felt-based multi-enzyme immobilized anodes to oxidize sucrose for biofuel cells. Chemphyschem. 2014;15(10):2145-51.

[128] Tsujimura S, Fujita M, Tatsumi H, Kano K, Ikeda T. Bioelectrocatalysis-based dihydrogen/dioxygen fuel cell operating at physiological $\mathrm{pH}$. Physical Chemistry Chemical Physics. 2001;3(7):1331-5. 
[129] Akers NL, Moore CM, Minteer SD. Development of alcohol/O2 biofuel cells using saltextracted tetrabutylammonium bromide/Nafion membranes to immobilize dehydrogenase enzymes. Electrochimica Acta. 2005;50(12):2521-5.

[130] Logan BE, Murano C, Scott K, Gray ND, Head IM. Electricity generation from cysteine in a microbial fuel cell. Water Res. 2005;39(5):942-52.

[131] Ghasemi M, Daud WRW, Hassan SHA, Oh S-E, Ismail M, Rahimnejad M, et al. Nanostructured carbon as electrode material in microbial fuel cells: A comprehensive review. Journal of Alloys and Compounds. 2013;580:245-55.

[132] Peter Clauwaert, David van der Ha, Nico Boon, Kim Verbeken, Marc Verhaege, Korneel Rabaey, et al. Open Air Biocathode Enables Effective Electricity Generation with Microbial Fuel Cells. Environ Sci Technol. 2007;41(21):7564-9.

[133] Zhen G, Lu X, Kobayashi T, Kumar G, Xu K. Promoted electromethanosynthesis in a two-chamber microbial electrolysis cells (MECs) containing a hybrid biocathode covered with graphite felt (GF). Chemical Engineering Journal. 2016;284:1146-55.

[134] Cercado-Quezada B, Delia M-L, Bergel A. Electrochemical micro-structuring of graphite felt electrodes for accelerated formation of electroactive biofilms on microbial anodes. Electrochemistry Communications. 2011;13(5):440-3.

[135] Li C, Zhang L, Ding L, Ren H, Cui H. Effect of conductive polymers coated anode on the performance of microbial fuel cells (MFCs) and its biodiversity analysis. Biosens Bioelectron. 2011;26(10):4169-76.

[136] Zhang Y, Sun J, Hu Y, Li S, Xu Q. Bio-cathode materials evaluation in microbial fuel cells: A comparison of graphite felt, carbon paper and stainless steel mesh materials. International Journal of Hydrogen Energy. 2012;37(22):16935-42.

[137] Rahimnejad M, Adhami A, Darvari S, Zirepour A, Oh S-E. Microbial fuel cell as new technology for bioelectricity generation: A review. Alexandria Engineering Journal. 2015;54(3):745-56.

[138] Feng C, Ma L, Li F, Mai H, Lang X, Fan S. A polypyrrole/anthraquinone-2,6-disulphonic disodium salt (PPy/AQDS)-modified anode to improve performance of microbial fuel cells. Biosens Bioelectron. 2010;25(6):1516-20.

[139] Almeida EC, Azevedo AF, Baldan MR, Braga NA, Rosolen JM, Ferreira NG. Nanocrystalline diamond/carbon felt as a novel composite for electrochemical storage energy in capacitor. Chemical Physics Letters. 2007;438(1-3):47-52.

[140] Qian Yang, Liubing Dong, Chengjun Xu, Kang F. High-performance supercapacitors based on graphene/MnO2/activated carbon fiber felt composite electrodes in different neutral electrolytes. RSC Advances. 2016;6:12525.

[141] He M, Zheng Y, Du Q. Three-dimensional polypyrrole/MnO2 composite networks deposited on graphite felt as free-standing electrode for supercapacitors. Materials Letters. 2013;104:48-52.

[142] Tan HT, Rui X, Shi W, Xu C, Yu H, Hoster HE, et al. Controlled Synthesis of Manganese Oxyhydroxide Nanotubes: Implications for High-Efficiency Supercapacitors. ChemPlusChem. 2013;78(6):554-60.

[143] Dincer I. Renewable energy and sustainable development: a crucial review. Renewable and Sustainable Energy Reviews. 2000;4:157-75.

[144] Hanaei H, Assadi MK, Saidur R. Highly efficient antireflective and self-cleaning coatings that incorporate carbon nanotubes (CNTs) into solar cells: A review. Renewable and Sustainable Energy Reviews. 2016;59:620-35.

[145] M. Torimura, A. Miki, A. Wadano, K. Kano, Ikeda T. Electrochemical investigation of cyanobacteria Synechococcus sp. PCC7942-catalyzed photoreduction of exogenous quinones and photoelectrochemical oxidation of water. J Electroanal Chem. 2001; 496:21-8. 
[146] K. Tanaka, R. Tamamushi, Ogawa T. Bioelectrochemical fuel-cells operated by the cyanobacterium, Anabaena variabilis. J Chem Tech Biotechnol. 1985;35B:191-7.

[147] T. Yagishita, S. Sawayama, K. Tsukahara, Ogi T. Performance of Photosynthetic Electrochemical Cells Using Immobilized Anabaena variabilis M-3 in Discharge/Culture Cycles Journal of Fermantation and Bioengineering. 1998;85(5):546-9.

[148] Seiya Tsujimura, Akira Wadano, Kenji Kano, Ikeda T. Photosynthetic bioelectrochemical cell utilizing cyanobacteria and water-generating oxidase. Enzyme and Microbial Technology. 2001;29:225-31.

[149] J.M. Tarascon, Armand M. Issues and challenges facing rechargeable lithium batteries. Nature. 2001; 414:359-67.

[150] Andy Fiedler, Andrew P. Vogt, Lukas Pfaffmann, Vanessa Trouillet, Jorg T. Breukelgen, Ralf Koppe, et al. Lithium-air battery cathode modification via an unconventional thermal method employing borax. RSC Advances. 2016;6:66307-10.

[151] E.O.Vilar, E.B.Cavalcanti, H.R.Carvalho, F.B.Sousa. Cr (VI) electromechimal reduction using RVG $400 O$ graphite felt as the electrode. Braz J Chem Eng. 2003;20:291-303.

[152] Chen G. Electrochemical technologies in wastewater treatment. Separation and Purification Technology. 2004;38(1):11-41.

[153] Park K-K, Lee J-B, Park P-Y, Yoon S-W, Moon J-S, Eum H-M, et al. Development of a carbon sheet electrode for electrosorption desalination. Desalination. 2007;206(1-3):86-91.

[154] Abdessalem AK, Oturan N, Bellakhal N, Dachraoui M, Oturan MA. Experimental design methodology applied to electro-Fenton treatment for degradation of herbicide chlortoluron. Applied Catalysis B: Environmental. 2008;78(3-4):334-41.

[155] Mehmet A. Oturan, Nihal Oturan, Claude Lahitte, Trevin S. Production of hydroxyl radicals by electrochemically assisted Fenton's reagent Application to the mineralization of an organic micropollutant, pentachlorophenol. Journal of Electroanalytical Chemistry 2001;507 96102.

[156] Petrucci E, Da Pozzo A, Di Palma L. On the ability to electrogenerate hydrogen peroxide and to regenerate ferrous ions of three selected carbon-based cathodes for electro-Fenton processes. Chemical Engineering Journal. 2016;283:750-8.

[157] Hammami S, Oturan N, Bellakhal N, Dachraoui M, Oturan MA. Oxidative degradation of direct orange 61 by electro-Fenton process using a carbon felt electrode: Application of the experimental design methodology. Journal of Electroanalytical Chemistry. 2007;610(1):75-84.

[158] Le TX, Nguyen TV, Yacouba ZA, Zoungrana L, Avril F, Petit E, et al. Toxicity removal assessments related to degradation pathways of azo dyes: Toward an optimization of ElectroFenton treatment. Chemosphere. 2016;161:308-18.

[159] Oturan MA, Guivarch E, Oturan N, Sirés I. Oxidation pathways of malachite green by Fe3+-catalyzed electro-Fenton process. Applied Catalysis B: Environmental. 2008;82(3-4):24454.

[160] Oturan MA. An ecologically effective water treatment technique using electrochemically generated hydroxyl radicals for in situ destruction of organic pollutants: Application to herbicide 2,4-D. Journal of Applied Electrochemistry 2000;30:475-82.

[161] Mohamed C. Edelahi, Nihal Oturan, Mehmet A. Oturan, Padellec Y, Bermond A, Kacemi KE. Degradation of diuron by the electro-Fenton process Environmental Chemistry Letters. 2003;1(4):233-6.

[162] Hanna K, Chiron S, Oturan MA. Coupling enhanced water solubilization with cyclodextrin to indirect electrochemical treatment for pentachlorophenol contaminated soil remediation. Water Res. 2005;39(12):2763-73.

[163] Diagne M, Oturan N, Oturan MA. Removal of methyl parathion from water by electrochemically generated Fenton's reagent. Chemosphere. 2007;66(5):841-8. 
[164] Sirés I, Garrido JA, Rodríguez RM, Brillas E, Oturan N, Oturan MA. Catalytic behavior of the $\mathrm{Fe} 3+/ \mathrm{Fe} 2+$ system in the electro-Fenton degradation of the antimicrobial chlorophene. Applied Catalysis B: Environmental. 2007;72(3-4):382-94.

[165] Pimentel M, Oturan N, Dezotti M, Oturan MA. Phenol degradation by advanced electrochemical oxidation process electro-Fenton using a carbon felt cathode. Applied Catalysis B: Environmental. 2008;83(1-2):140-9.

[166] Hammami S, Bellakhal N, Oturan N, Oturan MA, Dachraoui M. Degradation of Acid Orange 7 by electrochemically generated $(*) \mathrm{OH}$ radicals in acidic aqueous medium using a boron-doped diamond or platinum anode: a mechanistic study. Chemosphere. 2008;73(5):678-84. [167] Sires I, Guivarch E, Oturan N, Oturan MA. Efficient removal of triphenylmethane dyes from aqueous medium by in situ electrogenerated Fenton's reagent at carbon-felt cathode. Chemosphere. 2008;72(4):592-600.

[168] Ozcan A, Oturan MA, Oturan N, Sahin Y. Removal of Acid Orange 7 from water by electrochemically generated Fenton's reagent. J Hazard Mater. 2009;163(2-3):1213-20.

[169] Panizza M, Oturan MA. Degradation of Alizarin Red by electro-Fenton process using a graphite-felt cathode. Electrochimica Acta. 2011;56(20):7084-7.

[170] Rosales E, Iglesias O, Pazos M, Sanroman MA. Decolourisation of dyes under electroFenton process using Fe alginate gel beads. J Hazard Mater. 2012;213-214:369-77.

[171] Elaoud SC, Panizza M, Cerisola G, Mhiri T. Coumaric acid degradation by electro-Fenton process. Journal of Electroanalytical Chemistry. 2012;667:19-23.

[172] Lin H, Zhang H, Wang X, Wang L, Wu J. Electro-Fenton removal of Orange II in a divided cell: Reaction mechanism, degradation pathway and toxicity evolution. Separation and Purification Technology. 2014;122:533-40.

[173] Iglesias O, Gómez J, Pazos M, Sanromán MÁ. Electro-Fenton oxidation of imidacloprid by Fe alginate gel beads. Applied Catalysis B: Environmental. 2014;144:416-24.

[174] Labiadh L, Oturan MA, Panizza M, Hamadi NB, Ammar S. Complete removal of AHPS synthetic dye from water using new electro-fenton oxidation catalyzed by natural pyrite as heterogeneous catalyst. J Hazard Mater. 2015;297:34-41.

[175] Ammar S, Oturan MA, Labiadh L, Guersalli A, Abdelhedi R, Oturan N, et al. Degradation of tyrosol by a novel electro-Fenton process using pyrite as heterogeneous source of iron catalyst. Water Res. 2015;74:77-87.

[176] Barhoumi N, Labiadh L, Oturan MA, Oturan N, Gadri A, Ammar S, et al. Electrochemical mineralization of the antibiotic levofloxacin by electro-Fenton-pyrite process. Chemosphere. 2015;141:250-7.

[177] Sopaj F, Oturan N, Pinson J, Podvorica F, Oturan MA. Effect of the anode materials on the efficiency of the electro-Fenton process for the mineralization of the antibiotic sulfamethazine. Applied Catalysis B: Environmental. 2016;199:331-41.

[178] Özcan A, Atılır Özcan A, Demirci Y. Evaluation of mineralization kinetics and pathway of norfloxacin removal from water by electro-Fenton treatment. Chemical Engineering Journal. 2016;304:518-26.

[179] Lin H, Oturan N, Wu J, Zhang H, Oturan MA. Cold incineration of sucralose in aqueous solution by electro-Fenton process. Separation and Purification Technology. 2017;173:218-25.

[180] Özcan A, Atılır Özcan A, Demirci Y, Şener E. Preparation of Fe2O3 modified kaolin and application in heterogeneous electro-catalytic oxidation of enoxacin. Applied Catalysis B: Environmental. 2017;200:361-71.

[181] Belgin Gözmen, Mehmet A. Oturan, Nihal Oturan, Erbatur O. Indirect Electrochemical Treatment of Bisphenol A in Water via Electrochemically Generated Fenton's Reagent. Environ Sci Technol. 2003;37 (16):3716-23. 
[182] Irmak S, Yavuz HI, Erbatur O. Degradation of 4-chloro-2-methylphenol in aqueous solution by electro-Fenton and photoelectro-Fenton processes. Applied Catalysis B: Environmental. 2006;63(3-4):243-8.

[183] Jean Jacques Aaron, Oturan MA. New photochemical and electrochemical methods for the degradation of pesticides in aqueous media. Environmental applications. Turk J Chem 2001;25: 509-20.

[184] Mehmet A Oturan, Jean-Jacques Aaron, Nihal Oturan, Pinson J. Degradation of chlorophenoxyacid herbicides in aqueous media, using a novel electrochemical method. Pestic Sci 1999;55:558-62.

[185] Sirés I, Oturan N, Oturan MA, Rodríguez RM, Garrido JA, Brillas E. Electro-Fenton degradation of antimicrobials triclosan and triclocarban. Electrochimica Acta. 2007;52(17):5493503.

[186] Ruiz EJ, Hernández-Ramírez A, Peralta-Hernández JM, Arias C, Brillas E. Application of solar photoelectro-Fenton technology to azo dyes mineralization: Effect of current density, Fe2+ and dye concentrations. Chemical Engineering Journal. 2011;171(2):385-92.

[187] Thi Xuan Huong Le, Mikhael Bechelany, Joffrey Champavert, Cretin M. A Highly Active Based Graphene Cathode for Electro-Fenton Reaction. RSC Advances. 2015;5:42536 - 9.

[188] Pajootan E, Arami M, Rahimdokht M. Discoloration of wastewater in a continuous electro-Fenton process using modified graphite electrode with multi-walled carbon nanotubes/surfactant. Separation and Purification Technology. 2014;130:34-44.

[189] Miao J, Zhu H, Tang Y, Chen Y, Wan P. Graphite felt electrochemically modified in $\mathrm{H} 2 \mathrm{SO} 4$ solution used as a cathode to produce $\mathrm{H} 2 \mathrm{O} 2$ for pre-oxidation of drinking water. Chemical Engineering Journal. 2014;250:312-8.

[190] Popuri SR, Chang C-Y, Xu J. A study on different addition approach of Fenton's reagent for DCOD removal from ABS wastewater. Desalination. 2011;277(1-3):141-6.

[191] Guo S, Zhang G, Wang J. Photo-Fenton degradation of rhodamine B using Fe2O3-Kaolin as heterogeneous catalyst: characterization, process optimization and mechanism. J Colloid Interface Sci. 2014;433:1-8.

[192] Hassan H, Hameed BH. Fe-clay as effective heterogeneous Fenton catalyst for the decolorization of Reactive Blue 4. Chemical Engineering Journal. 2011;171(3):912-8.

[193] Sánchez-Sánchez CM, Expósito E, Casado J, Montiel V. Goethite as a more effective iron dosage source for mineralization of organic pollutants by electro-Fenton process. Electrochemistry Communications. 2007;9(1):19-24.

[194] Xu N, Zhang Y, Tao H, Zhou S, Zeng Y. Bio-electro-Fenton system for enhanced estrogens degradation. Bioresour Technol. 2013;138:136-40.

[195] Birjandi N, Younesi H, Ghoreyshi AA, Rahimnejad M. Electricity generation through degradation of organic matters in medicinal herbs wastewater using bio-electro-Fenton system. J Environ Manage. 2016;180:390-400.

[196] Zhuang L, Zhou S, Yuan Y, Liu M, Wang Y. A novel bioelectro-Fenton system for coupling anodic COD removal with cathodic dye degradation. Chemical Engineering Journal. 2010;163(1-2):160-3.

[197] Li Y, Lu A, Ding H, Wang X, Wang C, Zeng C, et al. Microbial fuel cells using natural pyrrhotite as the cathodic heterogeneous Fenton catalyst towards the degradation of biorefractory organics in landfill leachate. Electrochemistry Communications. 2010;12(7):944-7.

[198] Wang XQ, Liu CP, Yuan Y, Li FB. Arsenite oxidation and removal driven by a bioelectro-Fenton process under neutral pH conditions. J Hazard Mater. 2014;275:200-9.

[199] Chun-Hua Feng, Fang-Bai Li, Hong-Jian Mai, Li X-Z. Bio-Electro-Fenton Process Driven by Microbial Fuel Cell for Wastewater Treatment. Environ Sci Technol. 2010;44(5):1875-80. 
[200] Plakas KV, Sklari SD, Yiankakis DA, Sideropoulos GT, Zaspalis VT, Karabelas AJ. Removal of organic micropollutants from drinking water by a novel electro-Fenton filter: Pilotscale studies. Water Res. 2016;91:183-94.

[201] Ren G, Zhou M, Liu M, Ma L, Yang H. A novel vertical-flow electro-Fenton reactor for organic wastewater treatment. Chemical Engineering Journal. 2016;298:55-67.

[202] Rosales E, Pazos M, Longo MA, Sanromán MA. Electro-Fenton decoloration of dyes in a continuous reactor: A promising technology in colored wastewater treatment. Chemical Engineering Journal. 2009;155(1-2):62-7.

[203] Zhang L, Yin X, Li SFY. Bio-electrochemical degradation of paracetamol in a microbial fuel cell-Fenton system. Chemical Engineering Journal. 2015;276:185-92.

[204] Zhuang L, Zhou S, Li Y, Liu T, Huang D. In situ Fenton-enhanced cathodic reaction for sustainable increased electricity generation in microbial fuel cells. Journal of Power Sources. 2010;195(5):1379-82.

[205] Zhu X, Ni J. Simultaneous processes of electricity generation and p-nitrophenol degradation in a microbial fuel cell. Electrochemistry Communications. 2009;11(2):274-7.

[206] Luo Y, Zhang R, Liu G, Li J, Qin B, Li M, et al. Simultaneous degradation of refractory contaminants in both the anode and cathode chambers of the microbial fuel cell. Bioresour Technol. 2011;102(4):3827-32.

[207] Zhu X, Logan BE. Using single-chamber microbial fuel cells as renewable power sources of electro-Fenton reactors for organic pollutant treatment. J Hazard Mater. 2013;252-253:198203.

[208] Espinoza C, Romero J, Villegas L, Cornejo-Ponce L, Salazar R. Mineralization of the textile dye acid yellow 42 by solar photoelectro-Fenton in a lab-pilot plant. J Hazard Mater. 2016;319:24-33.

[209] Garcia-Segura S, Brillas E. Advances in solar photoelectro-Fenton: Decolorization and mineralization of the Direct Yellow 4 diazo dye using an autonomous solar pre-pilot plant. Electrochimica Acta. 2014;140:384-95.

[210] Garcia-Segura S, Cavalcanti EB, Brillas E. Mineralization of the antibiotic chloramphenicol by solar photoelectro-Fenton. Applied Catalysis B: Environmental. 2014;144:588-98.

[211] El-Ghenymy A, Cabot PL, Centellas F, Garrido JA, Rodriguez RM, Arias C, et al. Mineralization of sulfanilamide by electro-Fenton and solar photoelectro-Fenton in a pre-pilot plant with a Pt/air-diffusion cell. Chemosphere. 2013;91(9):1324-31. 